UNIVERSIDADE DE SÃO PAULO

ESCOLA DE ARTES, CIÊNCIAS E HUMANIDADES

PROGRAMA DE PÓS-GRADUAÇÃO EM GESTÃO DE POLÍTICAS PÚBLICAS

HENRIQUE CARLOS PARRA PARRA FILHO

Capacidades Estatais na coprodução de TICs governamentais de participação

São Paulo

2018 
HENRIQUE CARLOS PARRA PARRA FILHO

\title{
Capacidades Estatais na coprodução de TICs governamentais de participação
}

\author{
Versão corrigida
}

Dissertação apresentada à Escola de Artes, Ciências e Humanidades da Universidade de São Paulo para obtenção do título de Mestre em Ciências pelo Programa de Pós-graduação em Gestão de Políticas Públicas.

Versão corrigida contendo as alterações solicitadas pela comissão julgadora em 26 de abril de 2018. A versão original encontra-se em acervo reservado na Biblioteca da EACH/USP e na Biblioteca Digital de Teses e Dissertações da USP (BDTD), de acordo com a Resolução CoPGr 6018, de 13 de outubro de 2011.

Área de Concentração:

Análise de Políticas Públicas

Orientador:

Prof. Dr. José Carlos Vaz

São Paulo 
Autorizo a reprodução e divulgação total ou parcial deste trabalho, por qualquer meio convencional ou eletrônico, para fins de estudo e pesquisa, desde que citada a fonte.

Parra Filho, Henrique Carlos Parra

Capacidades estatais na coprodução de TICs governamentais de participação / Henrique Carlos Parra Parra Filho ; orientador, José Carlos Vaz. - 2018 142 f. : il.

Dissertação (Mestrado em Ciências) - Programa de PósGraduação em Gestão de Políticas Públicas, Escola de Artes, Ciências e Humanidades, Universidade de São Paulo, São Paulo.

Versão corrigida

1. Administração pública. 2. Governo eletrônico. 3. Tecnologia da informação. 4. Participação. I. Vaz, José

Carlos, orient. II.Título

CDD 22.ed. -350.0285 
Nome: PARRA FILHO, Henrique Carlos Parra

Título: Capacidades Estatais na coprodução de TICs governamentais de participação

Dissertação apresentada à Escola de Artes, Ciências e Humanidades da Universidade de São Paulo para obtenção do título de Mestre em Ciências do Programa de Pós-Graduação em Gestão de Políticas Públicas.

Área de Concentração:

Análise de Políticas Públicas

Aprovado em: 26 / 04 / 2018

\section{Banca Examinadora}

Prof. Dr. Martin Jayo

Universidade de São Paulo. Escola de Artes, Ciências e Humanidades

Profa. Dra. Maria Alexandra Viegas Cortez da Cunha

Fundação Getúlio Vargas, Escola de Administração de Empresas

Prof. Dr. Clóvis Henrique Leite de Souza

Instituto Federal de Educação, Ciência e Tecnologia, Campus Formosa 
Aos familiares e amigos, apoio e compreensão para este esforço. 


\section{Agradecimentos}

Agradeço ao amigo e orientador José Carlos Vaz, que me ensinou a realizar uma pesquisa. Sua enorme generosidade e seu conhecimento tornaram possíveis este trabalho.

Agradeço aos professores Andrea Rodrigues, Arnaldo Lanzara, Cecília Olivieri, Cristiane Kerches, Fernando Coelho, Jaime Crozatti e Renata Bichir por compartilharem seus conhecimentos e me acolherem no campo da Administração Pública. Agradeço ainda a todos professores e professoras, funcionários e funcionárias da EACH-USP.

Agradeço ao amigo e colega Raphael Borella, ponto de apoio nessa trajetória do mestrado. Aos amigos e colegas da graduação, Jesus Vasquez, Paula Buckvieser e Daniela Costanzo. Não houve a oportunidade de um agradecimento deste tipo antes e o apoio de vocês foi fundamental em todos aqueles anos.

Agradeço ao amigo Ricardo Poppi, com quem compartilhei não apenas essa investigação, mas a utopia que a move.

Agradeço Patricia Anette, amiga querida, pela revisão generosa.

Agradeço ainda aos meus pais, Elaine e Henrique e à minha avó, Felipa, pela compreensão que tiveram durante este esforço que nos torna um pouco mais ausentes. 
Tupi or not tupi, that is the question.

(ANDRADE, Oswald de. Manifesto Antropófago.) 


\section{RESUMO}

PARRA FILHO, Henrique Carlos Parra. Capacidades Estatais na coprodução de TICs governamentais de participação. 2018. 142 f. Dissertação (Mestrado em Ciências) - Escola de Artes, Ciências e Humanidades, Universidade de São Paulo, São Paulo, 2018. Versão corrigida.

Esta pesquisa lança mão do conceito de Capacidades de Governo Relacionadas à Utilização de TICs em Processos de Participação Social (CGTPS) e investiga o caso de produção do aplicativo digital da 3a. Conferência Nacional de Juventude para compreender quais capacidades estatais foram demandadas pelo Estado e como foram mobilizadas da Sociedade, contribuindo para o debate sobre capacidades estatais e governança digital para a coprodução de tecnologias governamentais digitais.

Palavras-chave: Capacidades Estatais. Governança Eletrônica. Coprodução. TICs.

Governança Digital. 


\begin{abstract}
PARRA FILHO, Henrique Carlos Parra. State Capacities in the co-production of government participation ICTs. 2018. 142 p. Dissertation (Master of Science) - School of Arts, Sciences and Humanities, University of São Paulo, São Paulo, 2018. Corrected version.

This research makes use of the concept of Government Capabilities Related to the Use of ICTs in Social Participation Processes (CGTPS) and investigates the case of production of the $3^{\text {rd }}$ National Youth Conference's digital application to understand what state capacities were demanded by the state and how they were mobilized from the Society, contributing to the debate on state capabilities and digital governance for the co-production of digital government technologies.
\end{abstract}

Keywords: State Capacities. Electronic Governance. Coproduction. ICTs. Digital Governance. 


\section{LISTA DE FIGURAS}

Figura 1 - Conceitos de E-gov, E-democracia e E-governança no debate sobre o Estado e TICs..........................................................................

Figura 2 - Arquitetura da tecnologia desenvolvida para a $3^{\text {a }}$. Conferência Nacional de

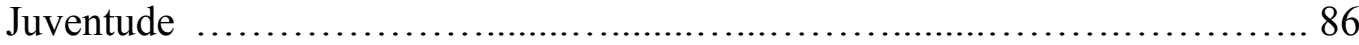

Figura 3 - Coprodução das tecnologias da $3^{\text {a }}$. Conferência Nacional de Juventude. .92 


\section{LISTA DE QUADROS}

Quadro_1 - Conceitos de Capacidades Estatais na literatura.............................19

Quadro 2 - Capacidades Estatais em uma abordagem relacional.......................26

Quadro 3 - Síntese sobre a produção brasileira recente de Capacidades Estatais. .30

Quadro 4 - Conceitos da literatura de Coprodução.............................................54

Quadro 5 - Modelos de Coprodução para Salm e Menegasso.............................57

Quadro 6 - Categorização de Capacidades de Governo....................................62

Quadro 7 - Composição teórica do conceito de Capacidade de Governo relacionada ao uso de TICs em processos participativos.................................6. 3

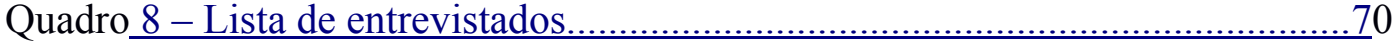

Quadro 9 - Sistematização das unidades de análise.....................................7 73

Quadro 10 - Relação geral de capacidades de governo relacionadas à utilização de

TICs em processo de participação social (CGTPS).......................................73

Quadro 11 - Classificação das unidades de análise .......................................74

Quadro 12 - Síntese das Unidades de Análise observadas...............................75

Quadro 13 - Dimensões do uso de TICs em Conferências....................................79

Quadro 14 - Regra de pontuação da etapa digital.............................................8

Quadro 15 - Perfil dos delegados da etapa digital......................................... 81

Quadro 16 - Aspectos de coprodução de TICs em Conferências Nacionais..........84 


\section{LISTA DE ABREVIATURAS E SIGLAS}

APF

CGTPS

COLIVRE

$\mathrm{CON}$

CONAE

CONSOCIAL

DITEC

DOU

INTOSAI

OEI

PNUD

PR

SCOT

Serpro

SGPR

SNAS

SNJ

STI

TICs

TCU

UNESCO
Administração Pública Federal

Capacidades de Governo Relacionadas à Utilização de TICs em

Processos de Participação Social

Cooperativa de Trabalho em Tecnologias Livres

Comissão Nacional Organizadora

Conferência Nacional de Educação

Conferência Nacional sobre Transparência e Controle Social

Diretoria de Tecnologia

Diário Oficial da União

International Organization of Supreme Audit Institutions

Organização dos Estados Ibero-americanos

Programa das Nações Unidas para o Desenvolvimento

Presidência da República

Construção Social da Tecnologia

Serviço Federal de Processamento de Dados

Secretaria Geral da Presidência da República

Secretaria Nacional de Articulação Social

Secretaria Nacional de Juventude

Secretaria de Logística e Tecnologia da Informação

Tecnologias de Informação e Comunicação

Tribunal de Contas da União

United Nations Educational, Scientific and Cultural

Organization 


\section{SUMÁRIO}

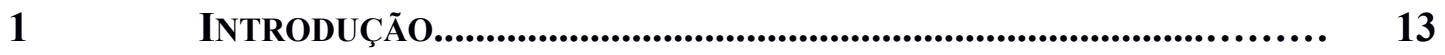

1.1 VISÃO GERAL E JUSTIFICATIVA................................................ 13

2 CONSTRUÇÃO DO REFERENCIAL TEÓRICO-CONCEITUAL............ 18

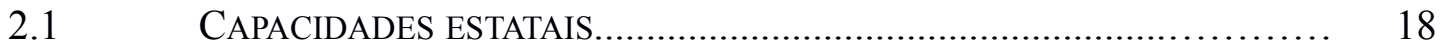

2.1.1 CAPACIDADE COMO UM CONCEITO POLISSÊMICO........................... 18

2.1.2 CAPACIDADE EM UMA ABORDAGEM RELACIONAL......................... 25

2.2 TICS E PARTICIPAÇÃO SOCIAL................................................... 31

2.2.1 CONSTRUÇÃO SOCIAL DA TECNOLOGIA....................................... 31

2.2.2 TICS E PARTICIPAÇÃO SOCIAL................................................ 34

2.2.3 TICS E CONFERÊNCIAS NACIONAIS........................................... 38

$2.3 \quad$ TICS E GOVERNO............................................................. 42

2.3.1 COPRODUÇÃO................................................................. 52

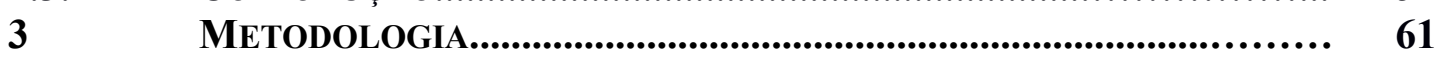

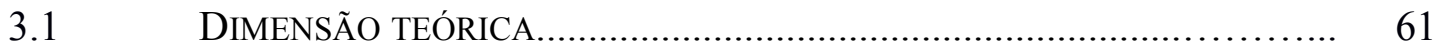

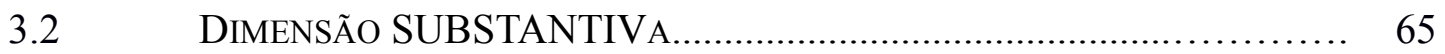

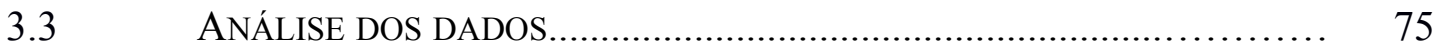

$4 \quad$ APRESENTAÇÃO DO CASO.............................................................. 77

4.1 HISTÓRICO DE CONSTRUÇÃO DO NOOSFERO.......................... 77

$5 \quad$ DISCUSSÃO............................................................................ 100

5.1 CAPACIDADES ESTATAIS TÉCNICAS............................... 100

5.1.1 RECURSOS HUMANOS......................................... 106

5.1.2 RECURSOS FINANCEIROS E FÍ́ SICOS ............................ 103

5.1.3 TECNOLOGIA................................................... 104

5.1.4 GESTÃo do PROCESSO PARTICIPATIVO................................ 106

5.2 CAPACIDADES ESTATAIS ADMINISTRATIVAS........................ 107

5.2.1 LÓCUS DO TEMA NO GOVERNO............................... 108

5.2.2 TI NA AdMINISTRAÇÃO PÚBLICA................................ 108

5.3 CAPACIDADES ESTATAIS POLÍTICAS............................... 112

5.3.1 PARTICIPAÇÃO COMO MÉTODO DE GOVERNO........................ 113

5.3.2 LIDERANÇA E CONDUÇÃO POLÍTICA.................................. 114

5.3.3 COMUNICAÇÃO................................................... 115

5.4 CAPACIDADES ESTATAIS INSTITUCIONAIS.......................... 115

5.4.1 INSTITUCIONALIDADE DO PROCESSO............................. 115

5.4.2 PlURALIDADE INSTITUCIONAL DO GOVERNO......................... 116

5.5 REFLEXÕES SOBRE O CONCEITO DE CAPACIDADES DE GOVERNO 118 RELACIONADAS À UTILIZAÇÃO DE TICs EM PROCESSOS DE PARTICIPAÇÃO SOCIAL (CGTPS)

6 CONCLUSÕES........................................................................ 124

$\begin{array}{llr}6.1 & \text { LIMITAÇÕES DA PESQUISA E } & 128\end{array}$

POSSIBILIDADES.

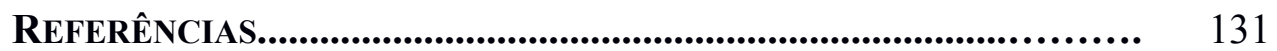

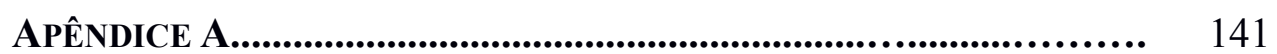




\section{INTRODUÇÃo}

\subsection{VISÃO GERAL E JUSTIFICATIVA}

O desenvolvimento da internet vem alterando profundamente as dinâmicas sociais, econômicas e políticas. Nos últimos anos o mundo tem assistido a diversas manifestações políticas que utilizam ou são construídas com o uso intenso de Tecnologias de Informação e Comunicação (TICs), graças às possibilidades que oferecem, com custo reduzido e significativa rapidez, diminuindo as barreiras associativas antes existentes (SHIRKY, 2012, pp. 23-25).

Alguns exemplos são as revoltas árabes; o movimento de indignados que passou a ter papel político de destaque na Espanha, com o \#15M e com o partido político Podemos; o movimento Sunflower, com a recente nomeação de Audrey Tang como Ministra Digital em Taiwan; e, no Brasil, os protestos e passeatas que tiveram grande relevância na dinâmica política desde junho de 2013.

Tais episódios e iniciativas seriam evidências do que esta pesquisa entende como a emergência de uma sociedade em rede que modifica as possibilidades da cidadania e da associação e colaboração entre sujeitos políticos. Esta visão é defendida por Manuel Castells (2008, p. 40) para quem o crescimento das redes interativas de computadores conectados pela internet estão "exponencialmente, criando novas formas e canais de comunicação moldando a vida e, ao mesmo tempo, sendo moldadas por eles".

Como Castells (2008), Yochai Benkler (2015) também aponta para estas profundas mudanças na estrutura social e para a emergência de um ambiente de informação em rede:

\footnotetext{
Internet ofrece hoy la posibilidad de una inversión radical de esta prolongada tendencia. Constituye el primer medio de comunicación moderno que expande su alcance mediante la descentralización del capital que estructura la producción y distribución de información, cultura y conocimiento. Gran parte del capital físico que integra la mayor parte de la inteligencia de la red está ampliamente difundido, siendo propiedad de los usuarios finales. Los enrutadores y servidores de la red no son cualitativamente distintos de los ordenadores que poseen los usuarios finales, a diferencia de lo que sucede con las emisoras de televisión o los sistemas por cable, que desde un punto de vista económico y técnico son radicalmente distintos de los televisores que reciben sus señales. Esta transformación básica en las condiciones materiales de la producción y distribución de información y cultura produce efectos sustanciales en el modo en que llegamos a conocer el mundo que habitamos y las alternativas de acción que se nos abren como individuos y como actores sociales. A través de estos efectos, el emergente entorno en red estructura cómo percibimos y perseguimos los principios políticos fundamentales de las sociedades liberales modernas. [...] La tecnología crea espacios de viabilidad para las prácticas sociales: en condiciones tecnológicas diferentes, algunas prácticas se vuelven más fáciles y
} 
baratas de hacer (o de impedir), y otras más difíciles y onerosas. (BENKLER, 2015, p. 66).

Ambos os autores indicam que a emergência deste novo ambiente informacional possibilitaria aos cidadãos produzir conteúdos e pautas, deixando a postura de receptores apenas. A partir dessa característica destacada pela literatura, surge uma grande variedade de conceitos: ciberdemocracia (LEVY, 2003); e-democracia (CUNHA, 2005) que também é o conceito adotado pela UNESCO; democracia eletrônica (PEIXOTO, 2010); e democracia digital (GOMES, 2011), apenas para dar alguns exemplos.

Do ponto de vista governamental brasileiro, desde 2009 vêm sendo desenvolvidas iniciativas de inovação tecnológica para a participação social, com destaque para o Cultura Digital $^{1}$, que baseou a consulta do Marco Civil da Internet; o Delibera/ Pensando o Direito ${ }^{2}$; o Noosfero/ Participa.br $r^{3}$; e as experiências de Conferências Nacionais que utilizaram ferramentas digitais. Já no Legislativo, o e-democracia da Câmara dos Deputados e o uso de ferramentas de enquete e votação online pelo Senado chamam a atenção. No entanto, embora as Tecnologias de Informação e Comunicação (TICs) tenham sido utilizadas pelos governos em inúmeros processos de participação no Brasil, Clóvis Souza (2016, p. 16) aponta que "a bibliografia especializada em instituições participativas pouco se dedicou às dinâmicas estatais na promoção da participação social”.

Dois esforços recentes buscaram ocupar esta lacuna; um deles foi feito pelo próprio Souza (2016) que analisou conferências nacionais sob a ótica de capacidades estatais; e o outro foi realizado por Anita Stefani (2015) na investigação sobre a consulta do Marco Civil da Internet realizada através do uso de TICs, também utilizando o referencial teórico de capacidades estatais.

Porém, estas investigações não enfatizaram os aspectos tecnológicos dos casos, como por exemplo o processo de escolha das tecnologias e softwares, bem como o seu processo de adoção, aprimoramento e desenvolvimento - justamente a dimensão escolhida nesta pesquisa,

\footnotetext{
O Ministério da Cultura lançou em julho de 2009 o Fórum da Cultura Digital Brasileira com o objetivo de agregar em uma plataforma web pessoas e fluxo de conteúdos ligados à construção de políticas públicas e marcos regulatórios para o digital. A plataforma estimulou a participação de mais de 7 mil integrantes, que criaram quase 2 mil blogs, 400 grupos de discussão e 500 fóruns, até julho de 2012. Debates importantes, como a criação do Marco Civil da Internet, proposto pelo Ministério da Justiça em 2010, usaram a rede não apenas como espaço de discussão, mas como ferramenta para a colaboração do público e sistematização de contribuições enviadas ao projeto de lei.

2 Delibera é um software livre para sugestão, voto e deliberação de ideias. Foi adotado pelo Ministério da Justiça para o desenvolvimento da plataforma Pensando o Direito

3 Noosfero é um software livre para redes sociais que possui as funcionalidades de Blog, e-portfólios, RSS, discussão temática e agenda de eventos. Foi adotado pela Secretaria de Governo (antiga Secretaria-Geral da Presidência da República) para o desenvolvido da plataforma Participa.br
} 
cuja questão é: quais são e como são mobilizadas as capacidades estatais necessárias à coprodução de TICs governamentais de participação social?

O pressuposto teórico assumido neste trabalho e fundamentado na literatura é que existem capacidades estatais específicas para a ação do Estado na coprodução de tecnologias digitais de participação social. Para isso, esta pesquisa considera tais capacidades estatais em quatro dimensões: institucional, política, administrativa e técnica (GRINDLE, 1996). Também assume uma abordagem relacional que entende tais capacidades estatais como atributos ou recursos de uma estrutura que podem ser gerados ou mobilizados a depender das necessidades. Como afirma Souza (2016), “capacidades são recursos para a ação estatal que podem ser mobilizados tanto no Estado como na sociedade, podendo estar disponíveis em certos momentos e posteriormente indisponíveis" (SOUZA, 2016, p. 15).

Interessa-nos identificar quais são os recursos demandados e compreender como são mobilizados - constituindo-se como capacidades - para a coprodução de TICs governamentais de participação social, no caso, do software desenvolvido e utilizado pela Secretaria Nacional de Juventude para a $3^{\text {a }}$ Conferência Nacional de Juventude, realizada em 2015 .

Assim, esta pesquisa busca contribuir especialmente com o debate sobre capacidades estatais que, no Brasil, vem adotando uma perspectiva relacional que analisa as relações entre Estado e Sociedade e, segundo Alexandre Gomide e Roberto Pires (2014, p. 20), investiga a atuação do Estado em contexto democrático, estudando as "habilidades da burocracia criar e expandir canais de interlocução com os atores sociais", mediando, negociando e processando os conflitos, bem como logrando a colaboração para efetivar suas preferências e decisões. Este marco referencial dá suporte para o estudo de objetos relacionados a arranjos, redes sociais ou governança. (GOMIDE; PIRES, 2012, 2014; PEREIRA, 2014; STEFANI, 2015; BICHIR, 2016; SOUZA, 2016). Essa abordagem relacional encontra espaço também em Carlos Matus (1993, 1994) e Michael Mann (2007) e será apresentada melhor durante a revisão empreendida no Capítulo 2.

A análise do fenômeno foi feita a partir da pesquisa em campo do caso de produção do software utilizado na $3^{a}$ Conferência Nacional de Juventude. Como será detalhado no Capítulo 3, a investigação seguiu o método do estudo de caso interpretativo, dentro da abordagem qualitativa, lançando mão do conceito de Capacidade de Governo para Utilização de TICs em Processos de Participação Social (STEFANI, 2015). 
O presente trabalho buscou enfatizar a dimensão tecnológica - pouco detalhada no estudo de Stefani - e também analisou as relações entre as distintas subcategorias que compõem o conceito dessa autora. Tais categorias foram como pontos de observação e seviram para perceber relações existentes entre elas à luz do caso investigado. Também foi possível estabelecer diálogo entre os resultados obtidos por cada uma das pesquisas, resultando em um aprofundamento no debate sobre o Capacidade de Governo para Utilização de TICs em Processos de Participação Social .

Para a melhor compreensão do fenômeno e do contexto que permeiam o objeto escolhido, foi realizada ainda no Capítulo 2 uma revisão das literaturas de Construção Social da Tecnologia (SCOT), e-participação e Conferências Nacionais, governo eletrônico e governança eletrônica, bem como sobre coprodução. A SCOT enfatiza a importância do estudo sobre o papel desempenhado por atores e grupos sociais no desenvolvimento de aparatos tecnológicos e das tecnologias (PINCH e BIJKER, 1984), referência conceitual que apoia esta pesquisa. A revisão sobre o debate de e-participação alargou a compreensão sobre os usos de tecnologias pelo governo e pela sociedade com objetivos de ampliar e aprofundar a participação política da sociedade nos processos de formulação e implementação de políticas públicas; assim como a literatura de Conferências Nacionais, que ofereceu elementos teóricos importantes para a definição deste fenômeno político e de que maneira o uso de TICs é visto como relevante ou desejável neste campo de debate.

De maneira semelhante ao que se observou na revisão sobre capacidades estatais, a literatura sobre governo eletrônico tem enfatizado cada vez mais as relações entre Estado e Sociedade a partir do desenvolvimento das TICs e da Internet e de uma postura mais ativa dos cidadãos, adotando uma perspectiva de governança digital (VAZ, 2005; CUNHA; MIRANDA, 2013; FOUNTAIN, 2005; GUIMARÃES; MEDEIROS, 2005). Esta ênfase possibilita diálogo com o conceito de coprodução (OSTROM, 1996), importante referencial para as investigações de processos de construção de políticas (serviços ou bens) com a participação de cidadãos, como a que faz esta pesquisa.

O próximo capítulo apresentará a revisão de literatura realizada, detalhando os debates com os quais essa pesquisa se relaciona. No Capítulo 3, as dimensões teórica, metodológica e empírica da metodologia utilizada serão apresentadas, bem como um panorama geral dos dados coletados. Já nos Capítulos 4 e 5 o caso estudado será detalhado e discutido, à luz dos conceitos escolhidos a partir da revisão de literatura e dos procedimentos de coleta e análise 
utilizados. Por fim, no sexto e último capítulo abordaremos as principais conclusões, limitações e considerações finais da pesquisa. 


\title{
2 CONSTRUÇÃo do REFERENCIAL TEÓRICO-CONCEITUAL
}

$\mathrm{Na}$ primeira seção deste capítulo apresentaremos a revisão bibliográfica realizada dentro do debate sobre capacidades estatais, principal referencial teórico para esta investigação. Além de recuperar os principais conceitos e autores deste debate, a revisão se concentra ainda na recente produção brasileira e em sua abordagem relacional, destacando dois trabalhos que oferecem contribuições diretas para a pesquisa de processos participativos.

A segunda seção apresenta a revisão realizada sobre as literaturas de Construção Social da Tecnologia, e-participação e Conferências Nacionais, governo eletrônico e governança eletrônica, bem como sobre coprodução. Como será apresentado ao longo do capítulo, elas ofereceram elementos conceituais relevantes para a análise do objeto desta investigação.

\subsection{CAPACIDADES ESTATAIS}

\subsubsection{Capacidade como um Conceito Polissêmico}

A revisão da literatura sobre capacidades estatais encontra, na produção brasileira mais recente (GOMIDE; PIRES; SÁ E SILVA, 2014; STEFANI, 2015; BICHIR, 2016; SOUZA, 2016) e no trabalho de Luciana Cingolani (2013) um esforço de mapear a polissemia conceitual existente, dadas as dificuldades de se estabelecer um debate entre as distintas categorias e abordagens existentes. Como aponta Cingolani (2013):

\begin{abstract}
A primeira e mais saliente é talvez a dificuldade de invocar capacidade estatal como um conceito genérico. Há vários aspectos da capacidade, sugerindo que uma compreensão ingênua dele pode ignorar conflitos e contradições importantes. Além disso, existem definições amplas e estreitas, em que as primeiras muitas vezes não conseguem distinguir-se de outras construções como o Estado de Direito, a governança ou a qualidade do governo. (CINGOLANI, 2013, p. 3 tradução própria)
\end{abstract}

Renata Bichir (2016) também chama atenção para a significativa polissemia presente no debate sobre capacidades estatais:

O conceito de capacidades estatais não deve ser compreendido de maneira essencialista e muito menos a-histórica. Nesse sentido, é importante analisar a variação nas capacidades estatais de acordo com mudanças nas agendas políticas ao longo do tempo. O que foi considerado "capacidade estatal" em um determinado contexto político-institucional por vir a ser obstáculo no momento seguinte, considerando-se o amadurecimento desses programas e os novos objetivos e desafios colocados para os mesmos no âmbito das agendas governamentais. (BICHIR, 2016, p. 117) 
Cingolani (2013) empreendeu uma exaustiva revisão da literatura de capacidades estatais, recuperando as principais gerações e diferenças entre os autores mais importantes deste campo de debate. O resultado é um panorama referencial para as investigações atuais, resumido em seu conceito de capacidades:

Em geral, a capacidade do Estado refere-se a uma ou uma combinação das seguintes dimensões do poder do Estado: A) coercitivo / militar; B) fiscal; C) administrativo / implementação; D) transformadora ou industrializante; E) cobertura relacional / territorial; F) legal; G) político. (CINGOLANI, 2013, p. 27)

Além deste conceito de capacidade estatal, Cingolani (2013) apresenta ainda um quadro-síntese de toda a revisão bibliográfica realizada em seu trabalho:

Quadro 1 - Conceitos de Capacidades Estatais na Literatura

(continua)

\begin{tabular}{|c|c|c|}
\hline Scholars & Conceptualization of state capacity & Dimension emphasized \\
\hline Huntington (1968) & $\begin{array}{l}\text { State capacity is the durability, complexity, } \\
\text { adaptability, coherance and autonomy of } \\
\text { organizations and proceadures (: } 12 \text { in Hanson and } \\
\text { Sigman 2011:5) }\end{array}$ & Bureaucratic/ administrative \\
\hline Tilly (1975) & $\begin{array}{l}\text { In the process of state formation in Western Europe, } \\
\text { Stateness is defined by the building of a repressive } \\
\text { state apparatus tha "effectively drew the necessary } \\
\text { resources from the local population and checked the } \\
\text { population's efforts to resist the extraction of } \\
\text { resources" (:40) }\end{array}$ & Coercive and fiscal \\
\hline Skocpol (1979) & $\begin{array}{l}\text { "Sovereign integrity and the stable administrative- } \\
\text { military control of a given territory are preconditions } \\
\text { for any state's ability to implement policies. Beyond } \\
\text { this, loyal and skilled officials and plentiful financial } \\
\text { resources are basic to state effectiveness in attaining } \\
\text { all sorts of goals." (:16) }\end{array}$ & Bureaucratic/ administrative \\
\hline Skocpol (1985) & $\begin{array}{l}\text { State capacity is the capacity to "implement official } \\
\text { goals, especially over the actual or potential } \\
\text { opposition of powerful social groups or in the face of } \\
\text { recalcitrant socioeconomic circunstances" }(: 9)\end{array}$ & $\begin{array}{l}\text { Bureaucratic/ administrative, } \\
\text { fiscal and coercive }\end{array}$ \\
\hline $\begin{array}{l}\text { Rueschemeyer and } \\
\text { Evans (1985) }\end{array}$ & $\begin{array}{l}\text { Effectiveness of state intervention in the economy. } \\
\text { Effective intervention requires a capable bureaucracy } \\
\text { and good coordination and coherance among state } \\
\text { organizations. }\end{array}$ & $\begin{array}{l}\text { Transformative and } \\
\text { administrative }\end{array}$ \\
\hline Levi (1988) & $\begin{array}{l}\text { The state's ability to provide collective goods by } \\
\text { raising revenue }\end{array}$ & Fiscal \\
\hline Evans (1986 1995) & $\begin{array}{l}\text { The key to state capacity is "embedded autonomy": a } \\
\text { combination of administrative insulation power and a } \\
\text { certain leve of state embeddednes in the productive } \\
\text { structure }\end{array}$ & $\begin{array}{l}\text { Relational, transformative and } \\
\text { bureaucratic }\end{array}$ \\
\hline
\end{tabular}




\begin{tabular}{|c|c|c|}
\hline Mann (1986 1993) & $\begin{array}{l}\text { Despotic power is "the range of actions the state elite } \\
\text { is empowered to undertake without routine, } \\
\text { institucionalized negotiations with civil society } \\
\text { groups (Mann, 1988: 59). Infraestructural power, on } \\
\text { the other hand, is "the capacity to actually penetrate } \\
\text { civil society and to implement political decisions } \\
\text { throughout the realm: (:59) }\end{array}$ & $\begin{array}{l}\text { Administrative, relational and } \\
\text { territorial reach }\end{array}$ \\
\hline Migdal (1988) & $\begin{array}{l}\text { Capacities are "the abilities of state leaders to use the } \\
\text { agencies of the state to get the people in the society } \\
\text { to do what they want them to do" (1988: prologue), } \\
\text { or to "achieve the kinds of changes in society that } \\
\text { their leaders sought throught state planning, policies } \\
\text { and actions" (:4). These include "the capacities to } \\
\text { penetrate society, regulate social relationships, } \\
\text { extract resources and appropriate or use resources in } \\
\text { determined ways" (:4) }\end{array}$ & Relational and territorial reach \\
\hline $\begin{array}{l}\text { Weaver and Rockman } \\
\text { (1993) }\end{array}$ & $\begin{array}{l}\text { They list ten universal state capacities, among which } \\
\text { are to maintain priorities; to innovate when old } \\
\text { policies fail and to guarantee effective } \\
\text { implementation of policies }\end{array}$ & Political and relational \\
\hline Geddes (1996) & $\begin{array}{l}\text { "The capacity to implement state-initiated policies } \\
\text { depends on the ability to tax, coerce, shape the } \\
\text { incentives facing private actors, and make effective } \\
\text { bureaucratic decisions during the course of } \\
\text { implementation. All of these abilities depend in turn } \\
\text { on the existence of effective bureaucratic } \\
\text { organizations." (:14) }\end{array}$ & $\begin{array}{l}\text { Fiscal, coercive and } \\
\text { administrative }\end{array}$ \\
\hline World Bank (1997) & $\begin{array}{l}\text { State's capability is defined as: the ability to } \\
\text { undertake and promote collective action efficiently } \\
(: 3)\end{array}$ & Political and relational \\
\hline Weiss (1998) & $\begin{array}{l}\text { The abilty to "device and implement policies that } \\
\text { augment a society's investible surplus" (:16) or, as } \\
\text { mentioned earlier, "the ability to coordinate industrial } \\
\text { change to meet the changing context of international } \\
\text { competition" (:7) }\end{array}$ & Transformative \\
\hline $\begin{array}{l}\text { Evans and Rauch } \\
\text { (1989) }\end{array}$ & $\begin{array}{l}\text { Weberianess is the degree to which core state } \\
\text { agencies are characterized by meriticratic recruitment } \\
\text { and offer predictable, rewarding long-term careers }\end{array}$ & Administrative \\
\hline Centeno (2002) & $\begin{array}{l}\text { State capacity is "the ability of the relevant political } \\
\text { authority to enforce its wishes and }\end{array}$ & Administrative and political \\
\hline $\begin{array}{l}\text { Fearon and Laitin } \\
(2003)\end{array}$ & $\begin{array}{l}\text { State capacity is "the government's police and } \\
\text { military capabilities and the reach of government } \\
\text { institutions into rutal areas" }(: 80)\end{array}$ & Coercive and territorial reach \\
\hline Fukuyama (2004) & $\begin{array}{l}\text { State capacity as "the ability of states to plan and } \\
\text { execute policies and enforce laws cleanly and } \\
\text { transparently" (:9) }\end{array}$ & Administrative and legal \\
\hline $\begin{array}{l}\text { Acemoglu, Ticchi } \\
\text { and Vindigmi (2006 } \\
2011)\end{array}$ & $\begin{array}{l}\text { State efficiency involves the abilities of a central } \\
\text { authority to monitor bureaucrats }\end{array}$ & Political and legal \\
\hline $\begin{array}{l}\text { Besley and Persson } \\
(2007 \text { 2009) }\end{array}$ & $\begin{array}{l}\text { High capacity is good enforcement of property rights } \\
\text { and contracts (2009: 1219) }\end{array}$ & Legal and fiscal \\
\hline Bäck and Hadenius & State capacity is multidimensional: monopoly of the & Coercive, fiscal, administrative \\
\hline
\end{tabular}




\begin{tabular}{|c|c|c|}
\hline (2008) & $\begin{array}{l}\text { military, monopoly of fiscal capacity, high } \\
\text { bureaucratic autonomy, monopoly of legal capacity }\end{array}$ & and legal \\
\hline Soifer (2008) & $\begin{array}{l}\text { Three approaches to infraestructural power: a) } \\
\text { relationship between the state and its 'radiating' } \\
\text { institutions; b) capability of the central } \\
\text { administration; c) territorial reach of the state }\end{array}$ & $\begin{array}{l}\text { Relational, administrative and } \\
\text { territorial reach }\end{array}$ \\
\hline $\begin{array}{l}\text { Besley and Persoon } \\
(2008)\end{array}$ & $\begin{array}{l}\text { "At the heart of state capacity lies the ability to levy } \\
\text { taxes to finance public goods and make transfers" } \\
(: 522)\end{array}$ & Fiscal \\
\hline Robinson (2008) & $\begin{array}{l}\text { Coordination of knowledge across fragmented sities } \\
\text { of governance }\end{array}$ & Relational \\
\hline Cardenas (2010) & $\begin{array}{l}\text { "State capacity is defined as the state's ability to } \\
\text { generate tax revenue from the public" }(: 15)\end{array}$ & Fiscal \\
\hline Kocher (2010) & $\begin{array}{l}\text { Five features of strong states that are falsifiable: a) } \\
\text { Centralization and unification; } b_{-} \text {wealth and taxing } \\
\text { capacity; c) professional bureaucracy; d) few } \\
\text { constraints on the regime; e) strong army }\end{array}$ & $\begin{array}{l}\text { Coercive, fiscal, administrative } \\
\text { and political }\end{array}$ \\
\hline $\begin{array}{l}\text { DeRouen et. Al. } \\
(2010)\end{array}$ & $\begin{array}{l}\text { Capacity is "the state's ability to accomplish those } \\
\text { goals it pursues, possibly in the face of resistence by } \\
\text { actors within the state" }(: 335)\end{array}$ & Coercive \\
\hline $\begin{array}{l}\text { McBride, Militante } \\
\text { and Skaperdas (2011) }\end{array}$ & $\begin{array}{l}\text { "We employ the term state capacity to denote the } \\
\text { level of commitment that can be achieved but which } \\
\text { can change over time under the influence of outsiders } \\
\text { as well as the actions of the major actors within } \\
\text { countries" (:448) }\end{array}$ & Legal \\
\hline $\begin{array}{l}\text { Dincecco and Prado } \\
(2012)\end{array}$ & $\begin{array}{l}\text { Fiscal capacity is "the ability of states to raise tax } \\
\text { revenues" (:172) }\end{array}$ & Fiscal \\
\hline $\begin{array}{l}\text { Besley and Persson } \\
(2011)\end{array}$ & $\begin{array}{l}\text { "Institutional capability of the state to carry out } \\
\text { various policies that deliver benefits and services to } \\
\text { household firms" (:6) }\end{array}$ & $\begin{array}{l}\text { Coercive, legal and fiscal } \\
\text { capacity }\end{array}$ \\
\hline $\begin{array}{l}\text { Hamm, King and } \\
\text { Stuckler (2012) }\end{array}$ & $\begin{array}{l}\text { State capacity is understood as the existence of } \\
\text { infrastructural power (Mann 1986): the ability of the } \\
\text { state to penetrate society and realize its objectives }\end{array}$ & Infrastructural, territorial reach \\
\hline Knutsen (2012) & $\begin{array}{l}\text { State capacity is understood as the successful } \\
\text { implementation of public policies through an } \\
\text { efficient rule-following bureaucracy }\end{array}$ & Administrative, legal and fiscal \\
\hline Fukuyama (2013) & $\begin{array}{l}\text { Capacity is defined by the inputs to the bureaucracy, } \\
\text { such as the level of education of government officials }\end{array}$ & Administrative \\
\hline
\end{tabular}

Fonte: Luciana Cingolani, 2013, pp. 29-30

A revisão apontada por Cingolani (2013) apresenta sete ênfases ou compreensões distintas para o conceito de capacidade estatal e nos ajudam a ter um panorama mais geral sobre parte importante dessa literatura. Tal esforço de síntese e de agregação é encontrado em Alexandre Gomide, Roberto Pires e Fábio de Sá e Silva (2014) e aparece ainda nos trabalhos de Stefani (2015) e Souza (2016). E a partir desses autores o presente trabalho assume que o conceito de statecapacity inicialmente se concentrou em uma agenda macro, que se remetia à criação e manutenção da ordem em um território, às medidas de soberania e à instituição de 
leis, impostos e justiça. Em suma, atributos do Estado para guiar a sociedade, administrando seus conflitos.

O conceito de capacidades estatais pode ser definido de diferentes formas, por diferentes autores. Em geral, engloba ao menos duas dimensões ou gerações de análise. [...] uma primeira geração de estudos sobre o tema, em grande parte dedicada às preocupações com a construção e formação de aparatos estatais (statebuilding), onde estes não existiam ou onde seriam frágeis e incipientes; ou com a autonomia do Estado em relação a atores econômicos e sociais específicos. (GOMIDE; PIRES; SÁ E SILVA, 2014, p. 236)

Em outras palavras, uma primeira geração do debate abordou a concepção clássica de Estado segundo Max Weber em “A política como vocação" (1918) conforme sua capacidade legislativa (impor leis), sua capacidade extrativa (cobrar impostos) e sua capacidade coercitiva (uso da força). Para Charles Tilly (1975, apud Cingolani, 2013), o nível de estatização pode ser determinado pela capacidade estatal de aumentar os impostos, ou seja, a capacidade de construir um aparelho estatal que extraia de modo eficaz os recursos da população. Considerado central para estes estudos - mais ligados à ciência política - o conceito de capacidades estatais inicialmente contribuiu pouco para o campo de estudos da burocracia.

No entanto, os aspectos redistributivos das políticas de bem-estar, que marcaram a ação estatal especialmente no período pós-guerra, chamaram atenção para uma certa autonomia relativa do Estado frente as classes dominantes, produzindo um intenso debate teórico e restabelecendo a relevância do Estado. Para Bob Jessop (2001) esta mudança se afirmou através "das teorias neomarxistas sobre o estado capitalista e nos finais dos anos setenta e oitenta através do movimento institucional estatista". Bichir (2016), recupera como o neoinstitucionalismo contribuiu para esta nova abordagem:

[...] destacam-se as contribuições do neoinstitucionalismo histórico, o qual ressalta a relevância de capacidades estatais para a configuração e a implementação de políticas públicas, enfatizando a autonomia relativa do Estado. [...] Segundo essa perspectiva, as próprias capacidades estatais podem ser medidas pelo grau de burocratização e de insulamento das burocracias: quanto mais insuladas das influências da sociedade, maiores seriam suas capacidades de formulação e implementação de políticas. Skocpol define capacidade estatal como "a capacidade de um Estado realizar objetivos de transformação em múltiplas esferas" (BICHIR, 2016, p. 116)

Nessa perspectiva, as capacidades estatais são atributos do aparato burocrático que dão força institucional, como dizem Steven Levitsky e María Victoria Murillo (2009 apud SOUZA, 2016, p. 48), "ao enforcement que é a capacidade de fazer valer as normas e decisões”. Ou nas palavras de Gomide, Pires e Sá e Silva (2014, p. 236), os estudos desta 
geração buscariam "refletir sobre os atributos que os Estados possuem (ou não) para atingir, de forma efetiva, os objetivos que pretendem por meio de suas políticas públicas".

Em outras palavras, a capacidade estatal é o poder de realizar a agenda definida de políticas, ainda que esta encontre resistências ou interferências de grupos sociais. Theda Skocpol (1985) define como a capacidade de "implementar metas operacionais, especialmente sobre a oposição real ou potencial de grupos sociais poderosos ou diante de circunstâncias socioeconômicas recalcitrantes" (SKOCPOL, 1985, p.9)

Por outro lado, nos primeiros trabalhos desta geração de estudos, há uma dificuldade de perceber a capacidade estatal como um fenômeno influenciado pelas relações entre o Estado e a sociedade, como nos mostra Ana Pereira (2014):

Cingolani (2013), após realizar uma extensa revisão de literatura sobre o tema, afirma que o termo "capacidade estatal" se refere a uma ou a combinação das seguintes dimensões do poder do Estado: coercitivo e militar, administrativo e de implementação, transformativo e de industrialização, relacional e de cobertura territorial, legal e político. Grande parte da literatura que aborda capacidade estatal foca bastante nas dinâmicas e nas características internas do Estado e de suas burocracias, como a qualificação técnico-administrativa e a autonomia. (PEREIRA, 2014, p. 27)

Esta mudança de abordagem dentro da literatura fica evidenciada pelos conceitos de “autonomia inserida" de Peter Evans (1993), de "capacidade de governo" de Carlos Matus (1993), ou ainda pelo conceito de "poder infraestrutural” de Michael Mann (1986).Para Evans (1993), “a capacidade de transformação exige uma combinação de coerência interna e conexão externa que pode ser chamada de 'autonomia inserida"' (EVANS, 1993). Para o autor, cada vez mais os conceitos de indução, coordenação e regulação deveriam estar presentes no debate sobre as capacidades do Estado.

Já para Michael Mann (1986), a capacidade do Estado está em penetrar na sociedade e realizar seus objetivos. Este seria o "poder infraestrutural", que possibilita ao Estado desenvolver seus projetos de maneira coordenada territorialmente, a partir das conexões organizacionais entre Estado e sociedade. Como apresenta Souza (2016), sobre a concepção de Mann (1986):

[...] não são apenas as atividades administrativas que possibilitam as ações do Estado, mas, em especial, as conexões entre os agentes estatais e não estatais. Portanto, nas capacidades estatais estariam as condições internas de ação (recursos disponíveis e modo de organização da burocracia), além dos arranjos institucionais que possibilitam as interações socioestatais. (SOUZA, 2016, p. 51)

Carlos Matus (1993) considera a capacidade de governo como constituintes do "triângulo de governo" formado por: capacidade de governo; projeto de governo (seus 
objetivos e sua agenda); e governabilidade do sistema. A capacidade de governo seria a força ou poder para vencer resistências em cada situação e contexto políticos e implementar a agenda em cada situação. Ou seja, sua categorização nunca seria isolada, autossuficiente ou descolada do ambiente sobre o qual incide. Segundo Stefani (2015, p.62), "seria a capacidade de um dado governo, em um dado contexto, para atingir um dado projeto". E complementa:

Essa ligação situacional da capacidade de governo com o contexto político específico do governo tem duas consequências para seu entendimento como variável relevante para o estudo das políticas públicas. A primeira é que, comportando-se de maneira situacional, a capacidade não pode ser vista como fixa, pois varia no tempo e de acordo com o contexto que, no ambiente político, evolui com grande dinamismo e de forma pouco predizível. Assim, uma dada capacidade pode ter significados diferentes em diferentes contextos. (STEFANI, 2015, p. 62)

Esta abordagem relacional apresentada por Mann (1986), Evans (1993) e Matus (1993) também encontrou espaço em uma parte do debate que passou a enfatizar as capacidades estatais e as interações entre Estado e sociedade, em contextos democráticos. Como apresenta Souza (2016):

[Para este ponto de vista] Um Estado capaz é aquele que tem condições de mediar as demandas para executar as políticas delas derivadas. Contribui com esse entendimento a visão de Grindle (1996, p. 7) em que o Estado capaz é aquele que tem condições de "ser responsivo às demandas e pressões de grupos sociais e de ser hábil para mediar demandas sociais e manter instituições que são efetivas na resolução de conflitos". (SOUZA, 2016, p. 52)

A abordagem relacional se move para além do conceito weberiano da burocracia, que enfatiza os componentes técnicos e administrativos. Dessa forma, o debate ganhou um campo interessante em direção ao conceito de governança, passando de debates que apenas "justapõem o Estado e a sociedade como oponentes para examinar a variedade de formas de interação", como afirmam Hillel Soifer e Matthias vom Hau (2008, p. 4 apud SOUZA, 2016, p. 52).

Essa abordagem reconhece as múltiplas formas de interações entre Estado e Sociedade existentes nos contextos democráticos e amplia a compreensão sobre as capacidades estatais necessárias e demandadas nestas relações. Nestes contextos, por exemplo, há uma multiplicidade de atores e interesses a serem coordenados para a produção e implementação de políticas, como por exemplo: partidos, burocracias dos governos subnacionais, burocracias do legislativo e do judiciário, parlamentares, sindicatos, movimentos sociais, associações de classe, etc. Gomide e Pires (2014) mencionam Lopez, Pires e Sá e Silva (2010) para descrever o contexto brasileiro:

A independência dos poderes da República, o advento das instituições participativas e a consolidação dos instrumentos de controle sobre a administração pública 
(burocrático, parlamentar e judicial) fazem com que os gestores públicos tenham que se relacionar, simultaneamente, com três sistemas institucionais na produção de políticas públicas, quais sejam: o representativo, o participativo e o de controles burocráticos (LOPEZ; PIRES; SÁ E SILVA, 2010 apud GOMIDE; PIRES, 2014, p. 17).

Gomide e Pires (2014, p. 20) se vinculam a esta abordagem relacional e, interessados em investigar as capacidades estatais no contexto democrático brasileiro, enfatizam dois componentes (o técnico-administrativo e o político) que compõem o conceito. O primeiro "deriva do conceito weberiano de burocracia, contemplando as competências dos agentes do Estado para levar a efeito suas políticas", já o segundo consistiria nas habilidades da burocracia criar e expandir canais de interlocução com os atores sociais, para negociar, processar conflitos e evitar a captura do Estado por grupos específicos.

A seguir os conceitos destes autores serão apresentados com mais detalhes, bem como sua contribuição para o debate atual sobre capacidades estatais, que tem influenciado de maneira singular a produção acadêmica brasileira nos últimos anos.

\subsubsection{Capacidade em uma abordagem relacional}

Assim como aquela segunda geração do debate de capacidades estatais passou a analisar o Estado em ação, com ênfase na burocracia, para entender o processo de produção de políticas e a realização da agenda governamental, esta "terceira geração" do debate passa a enfatizar capacidades de tipos político-relacionais, que segundo Gomide, Pires e Sá e Silva (2014)

[...] referem-se às habilidades da burocracia do Executivo em expandir os canais de inclusão, interlocução e negociação com os diversos atores, processando conflitos e prevenindo a captura por interesses específicos. É possível perceber tais capacidades a partir da existência de formas de interação das burocracias do Executivo com agentes do sistema político-representativo. (GOMIDE; PIRES; SÁ E SILVA, 2014, p. 237)

A partir desta abordagem desenvolvida na década de 1990, as pesquisas passaram a enfatizar a articulação entre burocracias e grupos sociais para o fortalecimento de políticas. Conforme esta perspectiva, o ambiente político-institucional promovido pela democracia passa a exigir do Estado (para a produção de políticas) mais do que apenas uma burocracia competente e profissional. Como afirma Anita Stefani (2015, p. 56) "a tradição brasileira e também latinoamericana, em relação à capacidade estatal tem sido evidenciar em um mesmo termo fatores políticos e sociais, de forma intrínseca e indissociável". 
É importante destacar que essa abordagem não descarta a perspectiva anterior - que inicialmente enfatizava o aspecto organizacional e administrativo - mas apenas ressalta o ângulo político como tão importante quanto aquela. Na verdade, autores relevantes para a segunda geração, como Skocpol (1985), também participam desta nova abordagem; e o esforço central da literatura passa a ser o de construir categorias de análise que entrelacem as dimensões democrática e burocrática, como apontam Gomide, Pires e Sá e Silva (2014, p. 19):

[...] este esquema analítico permite a percepção de gradações de capacidades ao longo dos dois eixos [político e administrativo] evitando categorizações dicotômicas em termos da existência ou não de capacidades políticas e técnico-administrativas. Todo arranjo institucional possuirá, em dado momento do tempo, capacidades e debilidades. (GOMIDE; PIRES; SÁ E SILVA, 2014, p. 19).

Merilee Grindle (1996) também fez esforço na mesma direção, apresentando o conceito de capacidades como sendo composto por quatro categorias - institucional, técnica, administrativa e política -, o que acaba por oferecer uma abordagem mais abrangente, que leva em conta e explicita diferentes dinâmicas e constitui ferramental metodológico útil para uma série de investigações. São categorias que apoiam a análise e favorecem a identificação de quais capacidades - desenvolvidas ou não - são mais importantes para determinada pesquisa. Já Gomide, Pires e Sá e Silva (2014), que entrelaçam as dimensões política e institucional, oferecem uma chave de análise mais sofisticada, permitindo uma análise das influências mútuas entre as capacidades destes dois tipos.

Além da revisão empreendida por Cingolani (2013) que esta pesquisa considera como referencial teórico, destacamos alguns dos autores (MANN, 1986; EVANS, 1993; MATUS, 1993; GRINDLE, 1996; GOMIDE; PIRES; SÁ E SILVA, 2014) que oferecem importantes contribuições para esta terceira geração do debate, que enfatiza a abordagem relacional:

Quadro 2 - Capacidades Estatais em uma abordagem relacional

(continua)

\begin{tabular}{|l|l|}
\hline Autor(a) & Conceito de Capacidade(s) Estatal(is) \\
\hline Mann (1986) & $\begin{array}{l}\text { É o poder de implementar políticas públicas e controlar o território, } \\
\text { podendo ser feito com ou sem a sociedade (despoticamente). No primeiro } \\
\text { caso (do poder infraestrutural), seriam as condições para o Estado } \\
\text { desenvolver seus projetos de maneira coordenada com organizações } \\
\text { territorialmente localizadas e também nas conexões organizacionais que } \\
\text { potencializam tais capacidades. }\end{array}$ \\
\hline Evans (1993) & $\begin{array}{l}\text { As capacidades estatais são atributos do aparato burocrático que revelam } \\
\text { seu desempenho potencial diante da necessidade de orientar a ação dos } \\
\text { sujeitos. É a capacidade de implementar metas oficiais, especialmente }\end{array}$ \\
\hline
\end{tabular}




\begin{tabular}{|l|l|}
\hline & $\begin{array}{l}\text { sobre a oposição real ou potencial dos grupos sociais ou circunstâncias } \\
\text { contextuais. }\end{array}$ \\
\hline Matus (1993) & $\begin{array}{l}\text { Acervo de técnicas, métodos, destreza, habilidades e experiências de um } \\
\text { ator e de sua equipe, necessário para a condução do processo social, dados } \\
\text { a governabilidade do sistema e o compromisso com o projeto de governo. }\end{array}$ \\
\hline Grindle (1996) & $\begin{array}{l}\text { Os recursos organizacionais, sejam eles institucionais, políticos, } \\
\text { administrativos ou técnicos, que dão base à ação das agências estatais são } \\
\text { compreendidos como capacidades estatais. }\end{array}$ \\
\hline Gomide; Pires; Sá e Silva (2014) & $\begin{array}{l}\text { Compostas por dois componentes: o técnico-administrativo e o político, } \\
\text { seriam condicionadas pelos arranjos institucionais, que dotam o Estado de } \\
\text { capacidade de execução de seus objetivos; ou seja, a capacidade estatal é } \\
\text { determinada pelos arranjos institucionais que dão sustentação à } \\
\text { implementação de políticas públicas. }\end{array}$ \\
\hline
\end{tabular}

Fonte: Henrique Carlos Parra Parra Filho, 2018

Estes autores têm influenciado fortemente as novas investigações e, seja metodologicamente, seja teoricamente, oferecido uma referência para o desenvolvimento de novas subcategorias, macrocategorias ou novos tipos. Alguns estudos produzidos recentemente no Brasil desenvolvem esta ênfase e, sob a ótica de capacidades estatais, investigam políticas públicas diversas. Por conta da ênfase relacional adotada, foram incluídas na revisão de literatura conceitual empreendida nesta pesquisa.

Ana Pereira (2014), por exemplo, busca compreender como as relações entre Estado e sociedade impactam a coordenação entre burocracias na construção de políticas. Para isso, aproxima as duas dimensões de Gomide e Pires (técnico-administrativo e político-relacional) e propõe uma nova divisão em três categorias (a capacidade participativa, a de poder decisório e a de coordenação interburocrática) para "detalhar como processos internos do Estado são influenciados pelo relacionamento entre Estado e sociedade" (PEREIRA, 2014, p. 54). A autora investiga o caso da construção da usina hidrelétrica de Belo Monte, no qual foi instituído comitê gestor com membros eleitos pela sociedade e por membros de distintos governos, municipais, estadual e federal, para decidir investimentos na região.

Conforme a autora, os distintos órgãos da burocracia pública envolvidos neste comitê precisam ter capacidade participativa para conhecer e negociar as demandas sociais, capacidade decisória para que tais demandas possam ser respondidas com ações públicas e entrar na agenda governamental e na capacidade de coordenação interburocrática, de maneira a conseguir colaboração entre os distintos órgãos e governos, necessária para a efetiva implementação de certas ações.

O componente relacional da capacidade estatal é traduzido por Soifer e Hau (2008) de duas maneiras: na interação entre grupos sociais e burocracia; no relacionamento entre as diferentes agências estatais. $\mathrm{O}$ primeiro tipo de relação fortaleceria as 
políticas estatais a partir do apoio social; enquanto a segunda seria essencial para a implementação de políticas por permitir uma coordenação entre as burocracias envolvidas e um mesmo projeto político. (PEREIRA, 2004, p. 39)

Renata Bichir (2016), como já foi dito, avança nas duas dimensões apresentadas por Gomide e Pires (2014) e descreve o que seriam quatro capacidades técnico-administrativas (existência de órgãos e agências com autoridade e alguma autonomia para formulação e implementação; disponibilidade, perfil e capacitação de recursos humanos; disponibilidade de recursos financeiros; instrumentos de regulação e transferência de recursos) e outras duas capacidades político-relacionais (formas de coordenação entre áreas governamentais e áreas governamentais e não-governamentais; construção de coalizões de apoio e formas de construção de legitimidade para as agendas propostas) que ajudariam a compreender a articulação entre as agendas de política de transferência de renda e de assistência social. A autoria o propõe a partir de uma abordagem relacional que destaca o papel das redes entre burocratas, o próprio governo federal e as burocracias subnacionais.

No caso da assistência social e da transferência de renda, alguns instrumentos de política criados de modo específico e set roail têm sido compartilhados, desde sistemas de monitoramento e gestão da informação até tecnologias sociais complexas e com grande potencial articulador, como o Cadastro Único. (BICHIR, 2016, p. 116)

Tal relação interburocrática estaria influenciada pelas capacidades políticas (espaços institucionais de participação e diálogo, como conselhos e conferências) como pelos instrumentos de distribuição de incentivos financeiros, já que recursos financeiros são transferidos aos governos subnacionais a partir de indicadores e do Cadastro Único, criando uma espécie de plataforma com a qual passam a se relacionar políticas e investimentos de outros órgãos estatais e governos - direcionando benefícios e investimentos em equipamentos e serviços públicos que priorizem os cadastrados, sob o guarda-chuva do Programa Brasil sem Miséria (PBSM):

[...] o PBSM gera um efeito catalisador dos usos do cadastro por muitos outros programas, a cargo de diferentes ministérios. Na fala de uma entrevistada da Senarc, o cadastro "de fato está virando Cadastro Único de Programa Sociais, como previsto desde 2001" - ainda que haja problemas de desarticulação institucional e fluxos pouco claros nesse processo. (BICHIR, 2016, p. 130)

Ambas as dimensões de categorias (técnico-administrativas e político-relacionais), bem como suas subcategorias (respectivamente, existência de órgãos com autoridade, perfil e capacitação dos recursos humanos, recursos financeiros, instrumentos de regulação e de transferência de recursos; e formas de coordenação, coalizões de apoio e formas de 
construção de legitimidade) são analisadas e descritas a partir desta associação entre agendas, enquanto capacidades para esta articulação.

Além destas duas pesquisas nas quais as relações interburocráticas são estudadas, há duas pesquisas recentes de Anita Stefani (2015) e Clóvis Souza (2016) que também assumem a abordagem relacional de capacidades estatais e investigam dois processos participativos promovidos pela Administração Pública Federal.

Clóvis Souza (2016) empreende pesquisa em que faz uso das quatro categorias apresentadas por Grindle (1996), mas sua abordagem relacional acaba por ampliar ou dar novos significados a cada uma delas. Ao analisar as Conferências Nacionais de políticas públicas - fenômeno político dos mais expressivos na política de participação social do Executivo Federal brasileiro, no qual a população pode participar elegendo delegados e propostas que se tornam uma agenda de prioridades posteriormente encaminhada pelo governo - sob a ótica das capacidades estatais, explorando cada uma das categorias propostas por Grindle (1996), o autor identifica as capacidades técnicas como sendo aquelas que mais importam de maneira específica a estes processos participativos, chegando a criar uma nova subcategoria da capacidade técnica, a de capacidade conversacional.

Ainda para Souza (2016), estariam nessas capacidades técnicas as condições para desenhar, facilitar e moderar os processos de diálogo entre Estado e sociedade, tão importantes em processos participativos:

O desconhecimento técnico metodológico para o desenho e desenvolvimento de processos participativos, acaba por provocar a gestão inadequada ou ineficiente de tais processos, diminuindo, assim, a qualidade da participação. [...] Em busca das condições para a ação do Estado na promoção da participação social na gestão. das políticas públicas, o achado deste trabalho foram as capacidades estatais que estão diretamente ligadas ao desenho e desenvolvimento de processos participativos. Elas dão condições às ações de promoção da participação, influenciando o modo de interação entre participantes, ou seja, a maneira como ocorrem as conversas. Foram aqui chamadas de capacidades conversacionais [...] (SOUZA, 2016, pp. 58-59)

Anita Stefani (2015) também investiga as capacidades estatais criadas ou mobilizadas em processos participativos, delimitando seu objeto a processos participativos que utilizam tecnologias de informação e comunicação (TICs). Assim como Souza (2016), lança mão das quatro categorias de Grindle (1996) de maneira articulada com a influência teórica de Gomide e Pires (e suas duas dimensões de capacidades) e com o conceito de capacidade de governo, de Matus (1993). Desta forma, articula a abordagem relacional (ênfase nos processos políticorelacionais) com as quatro categorias de capacidades, desenvolvendo o que seriam as CGTPS 
(Capacidades de Governo Relacionadas à Utilização de TICs em Processos de Participação Social).

Desta forma, o conceito de CGTPS pode ser sintetizado como o conjunto articulado de habilidades institucionais, técnicas, administrativas e políticas envolvidas na tomada de decisão, implementação e gestão de canais governamentais de participação social que utilizam TICs em um determinado contexto, político ou iniciativa. (STEFANI, 2015, p. 76)

Em suas investigações, Stefani (2015) identifica e descreve onze subcategorias em cada um dos quatro tipos de capacidades, de modo a identificar especificamente a ação do Estado para o desenvolvimento da consulta pública do Marco Civil da internet, caso analisado pela autora. Em sua análise, as capacidades de diferentes tipos se entrelaçam e afetam-se mutuamente e as CGTPS passam a ser uma espécie de meta-capacidade, ou de componente que dá ensejo para identificarmos elementos específicos dentro da tipologia de Grindle (1996) - o que acaba originando uma nova.

Uma breve sistematização destas análises pode ser encontrada na quadro abaixo, na qual tentamos destacar, para cada autor, a tipologia de referência utilizada - quando faz menção expressa; a abordagem relacional específica por ele construída; e se cunhou ou estabeleceu nova tipologia ou novo tipo específico de capacidade. Por fim, apontamos qual foi a política pública estudada por cada autor.

Quadro 3 - Síntese sobre a produção brasileira recente de Capacidades Estatais

(continua)

\begin{tabular}{|l|l|l|l|l|}
\hline & Pereira, A. (2014) & Stefani, A. (2015) & Bichir, R. (2016) & Souza, C. (2016) \\
\hline $\begin{array}{l}\text { Tipologia de } \\
\text { referência }\end{array}$ & $\begin{array}{l}\text { 2 dimensões } \\
\text { (Gomide) }\end{array}$ & $\begin{array}{l}\text { 4 tipos (Grindle), } \\
\text { mas também faz } \\
\text { menção às 2 } \\
\text { dimensões de } \\
\text { Gomide }\end{array}$ & $\begin{array}{l}\text { 2 dimensões } \\
\text { (Gomide) }\end{array}$ & $\begin{array}{l}\text { 4 tipos (Grindle), mas } \\
\text { também faz menção às } \\
2 \text { dimensões de Gomide }\end{array}$ \\
\hline $\begin{array}{l}\text { Abordagem } \\
\text { relacional }\end{array}$ & $\begin{array}{l}\text { Enfase nas } \\
\text { capacidades } \\
\text { relacionais para } \\
\text { investigar a } \\
\text { coordenação } \\
\text { interburocrática. } \\
\text { Reagrupa as } \\
\text { capacidades em 3 } \\
\text { novas categorias } \\
\text { (aproximando 2 } \\
\text { dimensões de } \\
\text { Gomide) }\end{array}$ & $\begin{array}{l}\text { Subcategorias dentro } \\
\text { da tipologia de } \\
\text { Grindle com ênfase } \\
\text { no debate com } \\
\text { sociedade e na } \\
\text { decisão tomada, } \\
\text { conformando espécie } \\
\text { de categoria mais } \\
\text { abrangente (CGTPS) }\end{array}$ & $\begin{array}{l}\text { Desenvolve } \\
\text { categorias de } \\
\text { Gomide, detalhando } \\
\text { em subcategorias } \\
\text { para investigar a as } \\
\text { sinergias e } \\
\text { articulação entre } \\
\text { políticas } \\
\text { intersetoriais }\end{array}$ & $\begin{array}{l}\text { Aproximação entre } \\
\text { papacida-relacional para } \\
\text { analisar conversação } \\
\text { (desenho, moderação e } \\
\text { facilitação dos } \\
\text { processos) }\end{array}$ \\
\hline Conceito criado & $\begin{array}{l}\text { 3 capacidades } \\
\text { (participativa, } \\
\text { poder decisório e } \\
\text { coordenação }\end{array}$ & $\begin{array}{l}\text { Capacidade de } \\
\text { governo relacionadas } \\
\text { à utilização de TICs } \\
\text { em processo de }\end{array}$ & $\begin{array}{l}\text { Subcategorias nas } \\
\text { dimensões propostas } \\
\text { por Gomide e Pires }\end{array}$ & $\begin{array}{l}\text { Capacidade } \\
\text { conversacional }\end{array}$ \\
\hline
\end{tabular}




\begin{tabular}{|l|l|l|l|l|}
\hline & interburocrática) & $\begin{array}{l}\text { participação social } \\
\text { (CGTPS) }\end{array}$ & \\
\hline Política estudada & $\begin{array}{l}\text { Política de } \\
\text { desenvolvimento } \\
\text { (Usina Belo Monte } \\
\text { no âmbito do } \\
\text { PDRS Xingu) }\end{array}$ & $\begin{array}{l}\text { Política de } \\
\text { participação social } \\
\text { com uso de TICs } \\
\text { (Marco Civil da } \\
\text { Internet) }\end{array}$ & $\begin{array}{l}\text { Política de } \\
\text { transferência de } \\
\text { renda e de } \\
\text { assistência social }\end{array}$ & $\begin{array}{l}\text { Política de participação } \\
\text { social (Conferências } \\
\text { Nacionais) }\end{array}$ \\
\end{tabular}

Fonte: Henrique Carlos Parra Parra Filho, 2018

O conceito de capacidades utilizado por esta pesquisa é o de "Capacidades de Governo Relacionadas à Utilização de TICs em Processos de Participação Social”, construído por Anita Stefani (2015) e que lança mão das quatro dimensões de capacidades estatais propostas por Grindle (1996) e da abordagem relacional apresentada nesta revisão.

\subsection{TICS E PARTICIPAÇÃO SOCIAL}

Aqui apresentaremos a revisão das literaturas de Construção Social da Tecnologia, eparticipação e Conferências Nacionais, governo eletrônico e governança eletrônica, bem como sobre coprodução. Esta seção será organizada em um tópico introdutório sobre Construção Social da Tecnologia (marco conceitual de referência) e seguirá analisando o uso de TICs em processos participativos, em Conferências Nacionais e pelo Estado de maneira geral, com destaque para o desenvolvimento do conceito de governança digital e a recente ênfase sobre processos que envolvem coprodução.

\subsubsection{Construção Social da Tecnologia}

A literatura de construção social da tecnologia entende que o desenvolvimento dos aparatos tecnológicos e das tecnologias não pode ser visto de maneira apartada ou isolada, sem considerar sua apropriação pela sociedade e o papel de atores e grupos sociais com poder sobre esse processo de desenvolvimento e adoção (PINCH; BIJKER, 1984). Em outras palavras "os processos que levam à consolidação de determinadas tecnologias e respectivos padrões de uso não são considerados tão espontâneos" (VAZ, 2017, p. 85).

$\mathrm{Na}$ verdade, tais atores e grupos podem ter um papel decisivo, pressionando ou tomando diretamente decisões sobre o curso da evolução destes artefatos. Janet Fulk (1993) é categórico sobre este ponto, ao afirmar que "Décadas de pesquisa em psicologia social 
demonstraram que grupos de trabalho formais são os locais de importantes influências sociais e processos de construção da realidade" (FULK, 1993, p. 924).

Trevor Pinch e Wiebe Bijker (1984) destacam o papel desempenhado pelos atores e grupos sociais desde o início do processo de desenvolvimento tecnológico, no momento de eleger e definir os problemas que devem ser objeto de respostas e soluções por parte destes artefatos:

In deciding which problems are relevant, a crucial role is played by the social groups concerned with the artefact, and by the meanings which those groups give to the artefact: a problem is only defined as such, when there is a social group for which it constitutes a 'problem'. (PINCH; BIJKER, 1984, p. 414)

De acordo com os autores, tais grupos seriam responsáveis pelos conflitos e negociações no decorrer do processo de desenvolvimento, sendo essenciais para o processo e seus resultados. Para Tamara Benakouche, Ricardo Alexandre de Moraes e Adalto Guesser (BENAKOUCHE et al., 2004, p. 18), “as posições destes grupos são motivadas por suas crenças, seus valores e pela sua capacidade de argumentação":

Dependendo do grupo, pode haver uma ou outra interpretação do processo, de seu
desenvolvimento e progresso, de sua utilidade e riscos. Estes diferentes tipos de
interpretações são caracterizados pela "flexibilidade interpretativa" (Bijker, 1997),
que deve ser sempre considerada como elemento fundamental da construção social
dos artefatos. Outro fator a ser considerado é que uma mesma controvérsia poderá
atingir públicos diferentes, com interesses e valores distintos [...]. (BENAKOUCHE
et al., 2004, p.18)

Outro papel de destaque assumido por estes grupos estaria na "desaparição" do problema, ou seja, quando estes grupos sociais relevantes percebem e estabelecem aquele problema como resolvido, encerrando a controvérsia presente durante o processo de desenvolvimento e gerando uma estabilização daquele artefato, como se este estivesse pronto, e o processo, concluído (PINCH; BIJKER, 1984).

Segundo os autores, durante o processo de desenvolvimento de soluções (aparatos) tecnológicas para resolver problemas, há uma série de soluções imaginadas e desenvolvidas, para uma sorte de problemas identificados e estabelecidos. Toda essa multiplicidade de problemas e soluções convivem em conflito e negociação, em um processo que vai definindo as escolhas e encerrando controvérsias. Para ilustrar este modelo, os autores apresentam a bicicleta enquanto artefato tecnológico. Se hoje é quase "naturalizada" enquanto um artefato quase óbvio e consensual, a bicicleta foi sendo desenvolvida em uma série de diferentes modelos e tipos, dando soluções a problemas diversos e o modelo final (estável nos dias de hoje) foi objeto de uma série de decisões. Pinch e Bijker (1984) resumem assim o modelo: 
Let us now return to the exposition of the model. Having identified the relevant social groups for a certain artefact (...), we are especially interested in the problems each group has with respect to that artefact (...). Around each problem, several variants of solution can be identified (...). This way of describing the developmental process brings out clearly all kinds of conflicts: conflicting technical requirements by different social groups (for example, the 'speed' requirement and the 'safety' requirement); conflicting solutions to the same problem (for example, the Safety Low Wheelers and the Safety Ordinaries - this type of conflict often results in patent litigation); and moral conflicts (for example, women wearing skirts or trousers on a High Wheeler). Within this scheme, various solutions for these conflicts and problems are possible - not only technological, but also judicial, or even moral (for example, changing attitudes towards women wearing trousers).(PINCH; BIJKER, 1984, p. 416).

Em resumo, o desenvolvimento dos aparatos tecnológicos não pode ser analisado sem levar em conta sua apropriação pela sociedade, que os transforma e influência em sua evolução. Assim, é fundamental interpretar essa apropriação e influência para entender o processo de construção de uma tecnologia. Um exemplo disso está no desenvolvimento de softwares livres. Para Benakouche et al. (2004):

A construção de softwares livres apresenta-se como um excelente exemplo de uma
controvérsia tecnocientífica contemporânea, pois seu processo constitui-se atualmente
de um amplo e conflituoso debate que extrapola o domínio dos peritos técnicos,
envolvendo todas as esferas da sociedade, do simples consumidor ao produtor, da
iniciativa privada aos governos, do diletante ao especialista. (BENAKOUCHE et al.,
2004, p. 19)

No caso do software livre, objeto de intensa controvérsia e disputa, os grupos também estão articulados em redes de relações de acordo com suas atividades, como por exemplo a comunidade de desenvolvedores, as empresas de tecnologia, as associações e os fóruns, os gestores e as lideranças políticas, as grandes empresas cujo negócio gira em torno da venda de licenças e patentes, etc. O fato é que sua adoção não é vista como solução padrão (estável), como é o caso da bicicleta.

A escolha por software livre ou proprietário, bem como as inúmeras escolhas que permeiam o processo de desenvolvimento de um novo software, revelam a intensa controvérsia, a negociação e as decisões tomadas por atores e grupos sociais a partir de suas relações, que marcam a construção de qualquer artefato. Por conseguinte, a escolha pelo desenvolvimento de softwares livres não leva em conta apenas os artefatos produzidos. Tratase de uma escolha por um processo distinto de construção de artefatos que possibilita a outras organizações e indivíduos executar aquele artefato para qualquer propósito, estudá-lo e adaptá-lo para suas necessidades, redistribuir cópias dele livremente e aperfeiçoá-lo, liberando estas melhorias inclusive para terceiros. 
Estas quatro liberdades ${ }^{4}$ do software livre possibilitam a apropriação sobre os artefatos tecnológicos e abrem espaço para iniciativas colaborativas envolvendo governo e sociedade para a coprodução. Ao mesmo tempo, a escolha pelo desenvolvimento de softwares livres por parte da Administração Pública Federal e a efetiva constituição de comunidades de desenvolvimento em torno destes artefatos (com múltiplos atores, organizações e indivíduos envolvidos) resultam em enormes impactos para as empresas públicas e privadas.

Como veremos na seção que trata de governo eletrônico, há uma intensa disputa pelo orçamento público destinado à tecnologia e ao desenvolvimento de softwares, com grandes organizações públicas (Serpro, Dataprev) e privadas interessadas na venda de licenças de uso ou no desenvolvimento de soluções proprietárias, que obriguem a contratação de uma mesma solução pelos diferentes órgãos da administração federal ou a contratação das versões atualizadas, mantendo relação de dependência com a administração pública. A escolha pela adoção e pelo desenvolvimento de softwares livres é uma escolha em um campo de intensa disputa.

Como foi ressaltado, a teoria da Construção Social da Tecnologia enfatiza as relações e interações entre atores, grupos e organizações. Esta abordagem relacional já foi destacada durante a revisão da literatura de capacidades estatais e também o será na revisão sobre governança digital. É uma ênfase comum ao debate sobre coprodução e, para esta investigação, condiz com o estudo do caso de desenvolvimento do software utilizado pela $3^{\text {a }}$ Conferência Nacional de Juventude, para a qual houve a produção conjunta deste artefato entre Estado e indivíduos da sociedade.

\subsubsection{TICS e participação social}

As modificações e transformações que as TICs e a internet vêm possibilitando na economia, na sociedade e na política são debatidas na literatura (CASTELLS, 2005, 2008; LEVY, 2003, 2011) e são um dos temas que mais tem atraído atenção trata das transformações na política (BENKLER, 2006, 2015; GOMES, 2011). Inúmeras investigações e pesquisas vêm tratando deste tema, ou de fenômenos políticos relacionados a ele (MARQUES, 2008; RIBEIRO, 2012; STEFANI, 2015). Para Manuel Castells (2005):

O nosso mundo está em processo de transformação estrutural desde há duas décadas. É um processo multidimensional, mas está associado à emergência de um novo paradigma tecnológico, baseado nas tecnologias de comunicação e informação, que

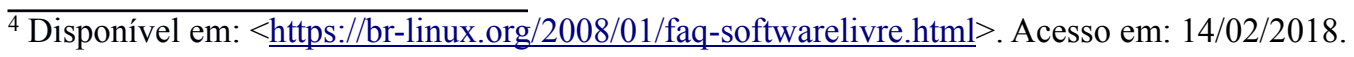


começaram a tomar forma nos anos 60 e que se difundiram de forma desigual por todo o mundo. Nós sabemos que a tecnologia não determina a sociedade: é a sociedade. (CASTELLS, 2005, p. 17)

Tais transformações apontam para uma sociedade em rede que, para Castells (2005), é uma nova estrutura social baseada em redes operadas por TICs e em redes digitais que geram, processam e distribuem informações. Manuella Ribeiro (2012) complementa destacando como a produção e distribuição destas informações, a partir das novas tecnologias, passam a ser feitas pelos indivíduos, que passam a poder assumir um papel mais ativo do que o que era possível na economia industrial. Pierre Levy (2011) resume esta ideia:

Condicionado pela mídia digital, o espaço público do século XXI é caracterizado, portanto, não só por uma maior liberdade de expressão, mas também por uma nova oportunidade de escolher as fontes de informação, assim como por uma nova liberdade de associação no seio de comunidades, grafos de relações pessoais ou conversas criativas que florescem na Rede. (LEVY, 2011, p.44)

Esta visão aceita a noção de esfera pública virtual, como bem aponta Francisco Marques (2008):

Isto é, [os autores] propõem que a internet funciona como um espaço efetivo e propício para a argumentação acerca da respublica (LÉVY, 2002; CASTELLS, 2001; SILVEIRA, 2000). A pluralidade de vozes e a possibilidade de combinação de "esferas públicas" (institucionais, temáticas, espontâneas, midiáticas) fariam com que a internet se tornasse apta a ser um ambiente discursivo por excelência. (MARQUES, 2008, p. 173)

Como dissemos, a literatura passa a investigar os impactos de tais transformações na democracia. Para Yochai Benkler (2006), por exemplo, com o avanço da sociedade em rede, os cidadãos poderiam exercitar novos papéis:

[O cidadão pode ser criador] de propostas políticas, sozinho ou em conjunto com outros indivíduos. Nessa [democracia interconectada], as novas tecnologias possuem um papel preponderante para fornecer ferramentas que conectem os cidadãos uns aos outros. (BENKLER, 2006)

Drica Guzzi (2010) reforça esta visão de que as tecnologias digitais possibilitariam novas formas e práticas sociais, superando a "comunicação caracterizada pela relação um a um, ou seja, de pessoa para a pessoa" para uma comunicação de um para muitos, na qual uma pessoa pode se conectar com milhares ou milhões. Em resumo, a reconfiguração das relações entre Estado e Sociedade e entre as próprias organizações e indivíduos possibilitaria reconfigurações do Estado e da Democracia. Levy resume assim o que seria o Estado em rede:

A governação é realizada numa rede, de instituições políticas que partilham a soberania em vários graus, que se reconfigura a si própria numa geometria geopolítica variável. Denominei isto como conceito de Estado em rede. [...] A 
transição de um estado-nação para um estado em rede é um processo organizacional e político lançado pela transformação da gestão política, representação e dominação nas condições da sociedade em rede. (LEVY, 2011, p. 26)

Cabe destacar que essa dissertação não tem o objetivo de colocar em debate as distintas abordagens de democracia ou mesmo eleger uma delas. Assim como Marques (2008), partimos da premissa de que

[...] a ideia de democracia é constituída por um conjunto de valores que ressaltam aspectos distintos, tais como transparência, visibilidade, liberdades políticas e participação (MARQUES, 2008, p. 24).

Isto posto, também cumpre destacar que esta dissertação não aprofundará sua revisão sobre os diversos pontos de vista acerca dos impactos das TICs na democracia. Assim como Manuella Ribeiro (2012), adotaremos a classificação que divide as distintas abordagens entre otimistas, pessimistas e neutras (ou moderadas). Esta revisão da literatura tem encontrado bastante aceitação e trabalhos e debates mais recentes, como o de Anita Stefani (2015), também o utilizaram. Ribeiro (2012) sintetiza assim:

Uma das principais classificações sobre as possibilidades de uso das TICs nos
processos democráticos se divide entre os otimistas e pessimistas (GOMES, 2005;
MARQUES, 2006; BENKLER, 2006, 201515; BEZERRA, 2008; MARQUES,
2008; PEIXOTO, 2009; BORGES \& JAMBEIRO, 2010; SAMPAIO, 2010;
PERNA, 2010). Essa classificação divide os teóricos que são mais crentes ou
descrentes quanto à melhoria da democracia decorrentes do uso das TICs
(RIBEIRO, 2012, p.47)

A presente pesquisa se alinha à abordagem moderada (ou neutra), que "compreende a esfera pública virtual enquanto um complemento para uma melhor formação cívica", mas sem efetivar a deliberação e as decisões plenas quanto à implementação das políticas públicas. (MARQUES, 2006, p. 172).

O desenvolvimento da internet possibilitaria a "interação mediada por tecnologia entre a esfera da sociedade civil e a esfera política formal, e entre a esfera da sociedade civil e a esfera da administração pública" (ZISSIS et al, 2009 apud CUNHA et al., 2015). Eis o conceito de e-participação apresentado por Cunha et al. (2015) e que está relacionado às transformações da participação em processos democráticos e consultivos mediados pelas TIC. Ainda para estes autores, tais "mecanismos de participação digital também exigem novas formas de gestão, de pensar a coisa pública, de governança, ao considerar o cidadão como participante" (CUNHA et al., p. 12). Os novos espaços de participação da sociedade implicam modelos inovadores de relacionamento governo-sociedade. Clelia Colombo (2006) vai em 
direção semelhante, indicando que o uso de TICs de participação em governos democráticos apresentaria quatro tipos de utilização e transformação:

(a) mecanismos de consumo, com foco na gestão de políticas e serviços públicos,
como elemento facilitador da eficácia e eficiência, concebendo os cidadãos como
consumidores; (b) alteração no elitismo democrático, que concedem novos canais de
participação, sem muito poder de tomada de decisão por parte dos cidadãos; (c)
redes pluralistas, que compartilham o poder de decisão entre cidadão e governo de
forma coletiva e conjunta; e (d) processos de democracia direta, que seriam, em
última instância, por meio de discussão e deliberação constantes. Sendo que os dois
primeiros (a) e (b), apesar de utilizarem as TICs, não alteram a lógica do sistema
representativo. Já os dois últimos possuem alto grau de inovação, pois se inserem
em uma perspectiva de participação social ativa, constante e horizontal, com
potencial para alterar a lógica unidimensional da representação tradicional.
(COLOMBO, 2006, p. 30)

Em outras palavras, as TICs poderiam reconfigurar a participação política, as relações entre Estado e Sociedade e as formas de gestão. No entanto, a Colombo (2006, p. 31) aponta que "Apesar das múltiplas potencialidades das TIC, se encontram dificuldades para conseguir mudanças radicais nos sistemas políticos através dos mecanismos tecnológi-cos", que estaria sendo feita "em um sentido unidireccional, sem aproveitar a interatividade que essas mídias permitem". Dessa forma, o estudo das capacidades estatais mobilizadas para a coprodução de TICs de participação está inserido em uma abordagem que enxerga, ao mesmo tempo, as potencialidades do uso de tecnologias para o aperfeiçoamento da representação e da deliberação por parte dos cidadãos e as limitações reais existentes para que tal potencialidade realmente tenha efeito.

Por sua vez, o conceito de e-democracia que esta pesquisa adotará é o que a entende como o uso das TICs nos processos democráticos. Esse conceito é adotado, por exemplo, pela UNESCO (United Nation Educational, Scientific and Cultural Organization), para a qual edemocracia, em sentido amplo, pode ser entendida como "uso dos meios eletrônicos no suporte à prática democrática" (UNESCO, 2004, s.p.), e encontra eco em autores como Cunha (2005), Colombo (2006) e Stefani (2015), que também entendem o uso de TICs nos processos políticos ou nas práticas democráticas. Ainda que para Colombo (2006) o conceito seja nomeado como democracia eletrônica, seu significado é comum ao estabelecido pelo conceito de e-democracia. Algo semelhante ocorre com Wilson Gomes (2011), que utiliza o conceito de democracia digital:

Entendo por democracia digital qualquer forma de emprego de dispositivos (computadores, celulares, smart phones, palmtops, ipads...), aplicativos (programas) e ferramentas (fóruns, sites, redes sociais, medias sociais...) de tecnologias digitais de comunicação para suplementar, reforçar ou corrigir aspectos das práticas políticas e sociais do Estado e dos cidadãos [...] (GOMES, 2011, pp. 27-28) 
Como veremos ao longo deste capítulo, o debate sobre governo eletrônico inicialmente enfatizou a informatização de processos administrativos e serviços governamentais, enxergando o cidadão como cliente, em uma postura mais passiva de consumo. Tal visão, conceituada como e-gov, foi sendo complementada pelos conceitos de edemocracia e e-participação, que passaram a enfatizar outra ideia a respeito da sociedade e do cidadão. Antes de aprofundar o desenvolvimento desse debate, cabe analisar a literatura sobre Conferências Nacionais e sua relação com as TICs.

\subsubsection{TICs e Conferências Nacionais}

As Conferências Nacionais de políticas públicas chamam atenção como um fenômeno político e uma ação estatal de estímulo à participação da sociedade, tanto por seu uso remontar à década de 1940, quanto pelas mudanças institucionais que elas foram sofrendo ao longo do tempo.

De 1941 a 2013 foram realizadas 138 conferências nacionais, das quais 97 aconteceram entre 2003 e 2013 abrangendo mais de 43 áreas setoriais nas esferas municipal, regional, estadual e nacional. Aproximadamente, nove milhões de pessoas participaram do debate sobre propostas para as políticas públicas - desde as etapas municipais, livres, regionais, estaduais até a etapa nacional. As etapas preparatórias (municipais, territoriais, temáticas) são momentos importantes e ricos no processo de uma conferência. É nelas que o debate se intensifica, tanto nos temas nacionais como nos locais, proporcionando ao cidadão oportunidade de propor soluções para os problemas da sua cidade, estado e do país. (SECRETARIA DE GOVERNO DA PRESIDÊNCIA DA REPÚBLICA, sem data, s.p.).

Segundo Clóvis Souza et al. (2013), as conferências foram ganhando um caráter mais mobilizador e de diálogo entre Estado e Sociedade a partir da Constitutição de 1988 e em especial a partir de 2003, recebendo maior importância, abarcando mais temas e ganhando maior periodicdade. Já o desenho institucional anterior privilegiava um caráter técnico-administrativo por reunir prioritariamente gestores do governo federal com gestores de governos subnacionais e por objetivar a criação de instrumentos para a articulação federativa e o aumento da racionalidade administrativa.

Mesmo que as Conferências não apresentem uma definição consolidada (INSTITUTO PÓLIS; INESC, 2011), e que a literatura admita haver "uma dificuldade em delimitar quais características definem as conferências enquanto fenômenos políticos" (SOUZA et al, 2013, p. 25), encontramos algumas definições com aspectos convergentes. (SOUZA et al. 2013; FARIA et al. 2012; AVRITZER, 2013; TEIXEIRA, SOUZA, LIMA, 2012). Para Claudia Feres Faria, Viviane Petinelli Silva e Isabella Lourenço Lins (FARIA et al., 2013) as 
conferências seriam espaços que integrariam a participação (incluindo politicamente), a representação (ao eleger delegados durante o processo) e a deliberação (ao promover a decisão e eleição de prioridades). Já Leonardo Avritzer (2013) define as conferências como "instituições participativas", constituindo uma das formas institucionalizadas que a sociedade civil reivindicou durante o processo constituinte: “(...) as conferências nacionais serão definidas como instituições participativas de deliberação sobre políticas públicas no nível nacional de governo, convocadas pelo governo federall e organizadas nos três níveis da Federação" (AVRITZER, 2013 p. 125).

Embora ainda haja distintas interpretações das conferências enquanto fenômeno político, Clóvis Henrique Leite de Souza, Isadora Araujo Cruxên, Paula Pompeu Fiuza Lima, Joana Luiza Oliveira Alencar e Uriella Coelho Ribeiro (2013) empreenderam o esforço de analisar todas as 82 conferências realizadas entre 2003 e 2011, conceituando-as como “(...) processos participativos de interlocução entre Estado e sociedade, convocados pelo Poder Executivo e desenvolvidos em etapas interconectadas a partir da escolha de representantes e da formulação de propostas para políticas públicas” (SOUZA et al. 2013, p. 26).

Para Paula Lima, Clóvis Souza e Ana Teixeira (2012), que analisaram as conferências realizadas entre 2003 e 2010, é possível identificar quatro tipos de objetivos que podem caracterizá-las:

(...) i) agendamento: quando se referiam a difusão de ideias, afirmação de compromissos, articulação entre atores, fortalecimento de redes, promoção de reflexões e debates ou troca de experiências; ii) análise: quando estavam em foco ações de diagnóstico de uma situação ou avaliação de políticas, inclusive avaliação do encaminhamento de deliberações de conferências; iii) participação: quando falavam em ampliação ou fortalecimento de espaços participativos na gestão de políticas públicas; e iv) proposição: quando traziam aspectos de formulação de estratégias ou políticas para garantia de direitos, articulação entre entes federados e financiamento de ações, identificação de prioridades de ação para órgãos governamentais, além de intenções de criação ou reformulação de planos, programas, políticas e sistemas. (TEIXEIRA, SOUZA, LIMA, 2012, p.19)

Concluindo esta delimitação sobre as Conferências Nacionais, para entender seus objetivos, seu desenho institucional e sua configuração, retomamos Souza et al. (2013):

\footnotetext{
As conferências são convocadas com objetivos e períodos definidos, podendo ser caracterizadas pela organização em etapas interconectadas. Uma etapa formula propostas e escolhe representantes que seguem às etapas seguintes. Ao final do processo é realizada a etapa nacional, momento em que as propostas são aprovadas e encaminhadas ao órgão responsável pela conferência, sem que isto implique, necessariamente, regulamentação por decreto ou outro instrumento normativo. Posteriormente, os conselhos podem se envolver em algum tipo de monitoramento das propostas formuladas durante o processo. (...) A existência de etapas interconectadas reforça o caráter processual das conferências e seu potencial mobilizatório. Além disso, cabe mencionar como aspecto usual a maneira de
} 
interconexão que passa pelo encaminhamento de propostas e pela seleção de representantes - tanto do governo como da sociedade - para as etapas seguintes. Assim, a escolha de representantes e a formulação de propostas podem ser vistos recorrentes na realização das conferências. (SOUZA et al. 2013, pp. 37-38)

Esse conceito de conferências apresentado por Souza et al. (2013) será utilizado nesta pesquisa para caracterizar o fenômeno político e institucional das conferências nacionais e possibilitar a investigação sobre a $3^{\text {a }}$ Conferência Nacional de Juventude.

Além da caracterização, estes autores que analisam as conferências também têm realizado uma série de balanços para identificar os limites e desafios deste instrumento. Nestes balanços, duas questões têm sido destacadas; garantir maior accountability entre cidadãos e representantes eleitos na conferência (incluindo os delegados da sociedade civil); e promover a inclusão de sujeitos políticos que não costumam se envolver nos processos de formulação de políticas públicas. A primeira delas analisa a necessidade de que a vinculação entre os delegados eleitos e o conjunto de participantes seja pensada de modo que os participantes possam acompanhar, cobrar e interagir com tais representantes. Neste caso, temse em conta não apenas a relação entre sociedade e governantes, mas especialmente entre sociedade e representantes eleitos na cota ou nos espaços de sociedade civil.

(...) estamos considerando o conceito de accountability em que os representantes da sociedade civil devem controlar o governo eleito e que devem ser controlados por aqueles que dizem representar. É o que Gurza Lavalle e Castello (2008) chamam de a dupla face da accountability (...). Como podemos perceber, esse controle dos representantes da sociedade nos espaços participativos nem sempre é possível dados os mecanismos disponíveis para organizações que participam dos conselhos e conferências. (TEIXEIRA, SOUZA, LIMA, 2012, p. 31)

Já no que diz respeito à inclusão de novos sujeitos políticos, ou seja, à capacidade de mobilizar e engajar públicos alheios à participação social (em especial aqueles que não estão envolvidos em organizações da sociedade civil), o potencial da internet e das TICs é apontado como uma das possibilidades de resposta, segundo Teixeira, Souza e Lima (2012):

Impulsionadas pelas ferramentas de interação a distância, em especial chats e fóruns de discussão na internet, foram também organizadas conferências virtuais. Esse tipo de mobilização foi experimentado em três temáticas: comunicação, cultura e segurança pública. Estas etapas preparatórias não elegeram representantes para etapas seguintes, mas o conteúdo discutido online foi considerado na formulação dos textos- base de encontros presenciais. Cabe destacar que a 2a Conferência de Cultura uniu a modalidade virtual com as conferências setoriais, abrindo a possibilidade até de eleger os representantes do setor via internet. O incremento no uso de tecnologias de comunicação e informação favorece conferências virtuais e pode inclusive respeitar novas formas organizativas da sociedade, pois potencialmente abre espaço para a participação de sujeitos políticos que antes não se envolveriam em um processo de formulação de políticas públicas (TEIXEIRA, SOUZA, LIMA 2012, p. 27). 
No entanto, as primeiras experiências de Conferências Nacionais que utilizaram tecnologias digitais no processo participativo (Cultura; Controle social e transparência; e Educação) não possibilitaram o uso de tecnologias digitais para a participação (inclusão de diferentes vozes), representação (agir em nome do outro) e deliberação (decisões tomadas com base em justificativas publicamente aceitáveis). A análise mais detalhada sobre como cada uma dessas Conferências utilizou tecnologias será apresentada ao Capítulo 4.

Para Faria, Silva e Lins (2012), "Essa diferenciação de formas de ação - participação, representação e deliberação - presentes na dinâmica de uma conferência, bem como a tentativa de integrá-las, coloca desafios não só analíticos como práticos”. (FARIA et al., 2012, p. 250)

Transpondo para a dinâmica de uma Conferência de Políticas Públicas, enquanto fenômeno político, a participação direta, a eleição de representantes (delegados) e a deliberação elegendo prioridades (propostas) seria a manifestação destas dimensões. No entanto, o que pode ser observado é que, se por um lado as conferências consolidaram uma dinâmica que atende estas três dimensões por meio das etapas municipais, estaduais e nacional, apenas a $3^{\text {a }}$ Conferência de Juventude utilizou a mediação de TICs com estes objetivos, ou seja, para atingir estas três dimensões. Teixeira, Souza e Lima (2012) apontam:

\footnotetext{
Outra questão ainda não resolvida nas inovações virtuais vistas neste ciclo de conferências, em particular nas conferências livres e virtuais, é a impossibilidade de eleição de representantes para as etapas seguintes. (...) Pensar em formas de escolha e inclusão de representantes das conferências livres e virtuais em conferências estaduais e nacionais talvez seja um passo necessário para a validação destas etapas e para a integração processual que caracteriza as conferências. Isso porque, ao inserir somente uma ideia, desconsiderando as pessoas que passam pelas experiências relacionadas ao tema que a ideia envolve, o conteúdo pode se perder no meio da luta política (TEIXEIRA, SOUZA, LIMA, 2012, p. 28).
}

A breve revisão realizada sobre parte da literatura de Conferências Nacionais ofereceu os elementos teóricos que tornaram possível compreender o que se entende desse fenômeno político e os principais conceitos que o descrevem e o caracterizam pelas dimensões participativa, representativa (eleição de delegados) e deliberativa (eleição de propostas e prioridades). Também possibilitou a compreensão de sua dinâmica de etapas (municipais, regionais e nacional) que se sucedem, elegendo representantes e propostas; bem como a compreensão da maneira pela qual sociedade e governos atuam em cada uma delas.

Além disso, apresentou o debate que essa literatura faz sobre o uso (potencial) de TICs nas Conferências Nacionais e as duas principais questões levantadas pelos autores, quais sejam: de um lado, a possibilidade de que o uso de tecnologias consiga incluir novos sujeitos 
políticos para além daqueles tradicionalmente engajados nas conferências (membros de partidos políticos, sindicatos e associações); de outro, a discussão sobre um uso que integre e potencialize as etapas online e offline, sem criar espaços desconexos ou concorrentes e evitando uma experiência fragmentada e limitada de uso das TICs. Tais pontos foram justamente ressaltados pelas entrevistas e pelos dados coletados, configurando duas marcas do caso estudado e dois objetivos do próprio desenvolvimento do software utilizado pela $3^{\mathrm{a}}$ Conferência Nacional de Juventude.

\subsection{TICS E GOVERNO}

A utilização de tecnologias digitais por parte dos governos passou a se desenvolver juntamente aos avanços da própria informática e do processamento de dados. No Brasil, este fenômeno também aconteceu. A informática pública inicialmente se concentrou na gestão interna (processos administrativos e de controle) e nas áreas financeira e fiscal. Vagner Diniz (2005) apresenta três fases que teriam distintas ênfases e prioridades:

De 1970 a 1992 - foco na gestão interna: aplicações voltadas para a melhoria da gestão interna e mais eficiência dos processos administrativos financeiros; De 1993 a 1998 - foco no serviço e informações ao cidadão: aplicações e processos voltados para apoiar a prestação de serviços ao cidadão pessoalmente ou via telefone; De 1999 a 2004 - foco na entrega de serviços via Internet: aprendizado e domínio das tecnologias da Internet como ferramenta e canal de entrega de serviços. (DINIZ, V. 2005, p. 3)

O uso estratégico das TICs em um novo modelo de gestão pública - com forte ênfase em eficiência, agilidade e otimização de recursos - evoluiu para o que passou a ser chamado de governo eletrônico. Dentre as causas para este fenômeno, podemos destacar o uso intensivo destas tecnologias por parte da sociedade (empresas e cidadãos), a migração da informação baseada em papel para as mídias digitais e o avanço da infraestrutura de telecomunicações e internet. Contudo, além destes fatores, Eduardo Diniz, Alexandre Fernandes Barbosa, Alvaro Ribeiro Botelho Junqueira e Otavio Prado (2009) destacam ainda que "Outras causas estão associadas às forças provenientes do próprio movimento de reforma do Estado, da modernização da gestão pública e da necessidade de maior eficiência do governo.” (DINIZ et al., 2009, pp. 24-25)

A ênfase, tanto das iniciativas governamentais, quanto da pesquisa relacionada, esteve na busca da eficiência, da otimização de recursos e da reforma administrativa (DINIZ, V. 2005; CUNHA; MIRANDA, 2013; DINIZ, E. et al., 2009). Já do ponto de vista 
organizacional e de gestão, o governo eletrônico esteve ligado diretamente ao desenvolvimento da própria informática pública, notadamente na criação das empresas públicas de processamento de dados. Eduardo Diniz, Alexandre Barbosa, Alvaro Junqueira e Otavio Prado (2009) recuperam este histórico:

Focando na estrutura do processo de informatização, Reinhard e Dias (2005) classificaram quatro grandes períodos do uso de TIC no setor público: pioneirismo (dos anos 1950 até meados dos anos 1960); centralização (de meados dos 1960 até o final dos 1970); terceirização (anos 1980) e governo eletrônico propriamente dito (a partir dos anos 1990). (DINIZ, E. et al., 2009, p. 25)

Nas duas fases iniciais, um modelo centralizado e monopolista (de Estado) prevaleceu. Já a partir dos anos 1990, um modelo de [quase] completa terceirização dos serviços foi dominante, graças à redução da capacidade de investimento do Estado na década de 1980 que também atingiu as empresas públicas de informática, privando-as dos recursos necessários à incorporação de novas tecnologias e aprofundando progressivamente uma defasagem entre as soluções e as práticas de baixo custo do setor privado em comparação com o setor público. Tais defasagens impulsionaram a compra e adoção intensas de tecnologias privadas (proprietárias) por parte do Estado, configurando efetivamente um novo modelo (por sua abrangência e disseminação). Como apresenta Vagner Diniz (2005):

O modelo baseado na adoção de soluções e serviços do setor privado sem uma
proteção de acordos de níveis de serviços tem gerado uma dependência dos órgãos
públicos em relação aos fornecedores externos. Muitos órgãos públicos têm todo o
seu corpo de funcionários da área de informática terceirizado, sem uma garantia de
retenção da inteligência dos negócios. A situação torna-se mais grave quando todas
as soluções utilizadas são de terceiros. Algumas empresas faliram ou deixaram o
país e os órgãos públicos sem solução de continuidade. (DINIZ, V. 2005, p. 9)

Este segundo modelo, no entanto, não acabou com as empresas públicas que até hoje existem na Administração Pública Federal e em governos estaduais e municipais. Pode-se dizer que mecanismos e estruturas de ambos os modelos passaram a conviver.

Se por um lado o modelo monopolista sofreu para manter competitividade e em determinado momento deixou de ser visto como uma alternativa viável frente as demandas e agendas de modernização da gestão pública, por outro, o modelo de terceirização também deu mostras de suas limitações, com as dificuldades de adaptação de tecnologias desenhadas originalmente para processos da administração privada, aumentando custos e riscos de manutenção e atualização dos sistemas (com as eventuais descontinuidades), bem como a dependência extrema e baixa autonomia para a gestão destes sistemas.

Progressivamente, a ênfase desse debate sobre uso de TICs por parte do governo passou a ser na relação entre Estado e Sociedade por meio da prestação de serviços e não mais 
apenas para a informatização dos processos administrativos e atividades internas do aparato burocrático. Há distintas concepções de governo eletrônico, ou e-gov, presentes na literatura. Para a International Organization of Supreme Audit Institutions (INTOSAI, 2003, p. 3 apud GUIMARÃES; MEDEIROS, 2005, p. 2), trata-se da "oferta e troca de informações e serviços governamentais on-line para cidadãos, empresas e outras agências governamentais". Já as Nações Unidas (2002, p. 1) entendem e-gov como a "utilização da Internet e da web para ofertar informações e serviços governamentais aos cidadãos”.

Já para Roberto Meizi Agune e José Antônio Carlos (2005, p. 309), governo eletrônico seria "um conjunto de ações modernizadoras vinculadas à administração pública" e, além de uma das principais formas de modernização do Estado, estaria "fortemente apoiado numa nova visão do uso das tecnologias para a prestação de serviços públicos”.

Pierre Levy e Andre Lemos (2010) buscam no debate inglês sobre e-gov (referência importante tanto para a literatura, quanto para uma das pioneiras e principais experiências aplicadas no setor público) um conceito mais amplo:

\begin{abstract}
A doutrina inglesa do e-government tem o mérito de ser clara. Trata-se simplesmente de aplicar ao serviço público os métodos do e-business que já deram provas em termos de eficácia e transparência. [...] Um documento oficial assim define os quatro princípios fundamentais do governo eletrônico: Construir serviços em torno das escolhas dos cidadãos (e não em torno dos fechamentos e privilégios da administração); Tornar o governo e seus serviços mais acessíveis (notadamente pela Internet); Incluir as populações desfavorecidas pelas formas tradicionais de governo (serviços para as minorias linguísticas, os deficientes, os expatriados, os estrangeiros); Melhor utilizar a informação, em particular com a conexão de sistemas de informações hoje separados. (LEVY; LEMOS, 2010, p. 139)
\end{abstract}

No entanto, Jane Fountain (2005) aponta que a mera adoção por parte dos governos de tecnologias produzidas pela iniciativa privada mostram certas limitações:

Penso que a maioria das empresas privadas não compreende a diferença entre o
governo e organizações do sector privado, e a maior parte delas não considera que
seja da sua responsabilidade compreendê-la. É por isso fundamental, que os
funcionários públicos percebam a diferença entre um sistema construído para o
sector privado, e os requerimentos necessários aos sistemas do Governo. As
empresas que vendem estes sistemas, geralmente não atribuem a devida importância
à necessidade de poder responsabilizar, que é uma das tarefas do Estado, tratamento
justo e igual dos cidadãos, acesso, transparência e acima de tudo, segurança e
privacidade. (FOUNTAIN, 2005, p. 169)

Em que pesem as diferenças de enfoque e de conceitos empregados, para Vaz (2005, p. 2), “os autores compartilham a mesma noção de governo eletrônico como aplicação intensiva das TIC aos processos de prestação de serviços e relacionamento dos governos com os cidadãos". 
O governo eletrônico enfatiza, portanto, a melhoria da gestão pública e da prestação de serviços a partir de instrumentos inspirados ou copiados da gestão empresarial, com ênfase na transparência e na eficiência. Este conceito se inseriu em um debate mais amplo de reforma e modernização dos Estados e acompanhou os avanços tecnológicos e de infraestrutura digital. Do ponto de vista da relação entre Estado e Sociedade, os serviços (prestados e consumidos) eram o objeto principal, com uma visão de foco no cliente. Assim como Leonardo Germani (2016), entendemos por serviços digitais aqueles serviços governamentais prestados e acessíveis por meios digitais (em especial a Internet): "São serviços em que o usuário não interage diretamente com seres humanos, sendo todo os seus procedimentos conduzidos por meios digitais através de interfaces previamente programadas para este fim" (GERMANI, 2016, p. 5).

Para o caso brasileiro, pode-se descrever o início da política de governo eletrônico no país (pelo menos com a ênfase em serviços públicos com foco no cliente/usuário) a partir do Decreto Presidencial de 3 de abril de 2000, que criou o Grupo de Trabalho Interministerial, responsável por examinar e propor políticas e diretrizes relacionadas com as novas formas eletrônicas de interação. Como apresentam Eduardo Diniz, Alexandre Barbosa, Alvaro Junqueira e Otavio Prado (DINIZ, E. et al., 2009, p. 36) as ações e normas concentraram-se em construir um amplo conjunto de serviços na internet e um portal único de serviços digitais, priorizando a incorporação das TICs aos processos administrativos e à prestação de serviços ao cidadão. Esta percepção é compartilhada por Cunha e Miranda (2013):

Nas áreas de governança eletrônica no Brasil, projetos de grande publicidade a partir
dos anos 90 foram os de prestação de serviços públicos por meios eletrônicos.
Percebe-se que governos das esferas municipal, estadual e federal vêm
desenvolvendo esforços, desde a segunda metade da década passada, para utilizar a
World Wide Web como um canal de prestação de serviços públicos e de informação a
cidadãos e organizações. A prestação de serviços eletrônicos através da Internet, em
muitos textos, é usualmente entendida como "e-gov". (CUNHA; MIRANDA, 2013,
p. 549)

Depois de uma primeira geração de uso focado na informatização dos processos administrativos, o uso de tecnologias por parte do governo passou a colocar ênfase nos serviços governamentais, ou seja, nas atividades que envolvem a sociedade. Um terceiro momento desse debate, graças ao avanço da internet, tem a ver com as novas práticas políticas assumidas pela sociedade em sua relação com o Estado. As demandas por participação, transparência e controle social ganham impulso a partir das novas tecnologias, com impactos para o debate sobre e-gov e para as iniciativas governamentais. Para Cunha e Miranda (2013): 
[...] os mecanismos de participação exigem novas formas de gestão, de pensar a coisa pública, de governança considerando o cidadão como participante da definição da agenda política, da sua implementação, agente de monitoramento e não apenas objeto da sua ação. (CUNHA; MIRANDA, 2013, p. 552)

Visão complementada por José Carlos Vaz (2016):

Os desenvolvimentos dos aparatos tecnológicos associaram-se ao surgimento de novos padrões de apropriação e mudanças na cultura de uso da tecnologia, respaldados em novos padrões cognitivos na interação com sistemas e dispositivos. Essas transformações não ocorrem apenas no nível do indivíduo, mas associam-se também a novas formas de relacionamento e de intervenção dos atores sociais como, por exemplo, o ativismo digital, com iniciativas e grupos atuando politicamente a partir de plataformas digitais. No campo das políticas culturais, o ativismo digital vem associado à expansão da cultura digital livre (VAZ, 2016, p.4).

As estratégias e usos governamentais passaram a considerar estas novas possibilidades - e mesmo serem pressionados por elas. Assim, a visão da sociedade como cliente dos serviços passa a ser considerada insuficiente. O relatório de pesquisa "Governança eletrônica local" da Rede LOGOLINK resume assim:

A disseminação do uso das tecnologias da informação e comunicação (TICs) pela Administração Pública e pelos cidadãos propiciou o desenvolvimento de um espaço virtual na relação entre governo e sociedade. Em outras palavras, um novo campo de disputas e conflito social foi estabelecido, com possibilidades de ampliação da participação cidadã, do engajamento cívico e do controle social sobre as atividades governamentais através do uso destas tecnologias (LOGOLINK, 2010).

Questões como a participação social - o cidadão como usuário, como participante e como coprodutor - e as mudanças nas relações entre Estado e Sociedade e da ação governamental ganham destaque em parte da literatura (COLOMBO, 2006; FERGUSON, 2002; GERMANI, 2016; GUIMARÃES; MEDEIROS, 2005; MILAKOVICH, 2012; RUEDIGER, 2002; VAZ, 2017). Para Clelia Colombo (2006):

As TICs, por suas características de relações horizontais, multiplicidade de atores, funcionamento descentralizado e não delimitado geograficamente, permitem - com facilidade a nível técnico - superar o sistema de representação tradicional e avançar até uma democracia representativa com uma forte participação cidadã, mantendo o sistema de deliberação social. Desta forma, facilitariam a transição de uma forma de governo tradicional a uma forma de governo relacional denominada governance, incorporando-se a um sistema complexo que introduz a participação de vários atores no governo e envolve mudanças nos papéis do poder público, e a posição que adota nos processos de governo e na utilização de novos instrumentos de governo. Neste marco de governança eletrônica se potencializam formas de participação eletrônica diversas. (COLOMBO, 2006, p. 32)

Justamente as novas práticas políticas possibilitadas pelas TICS, já descritas anteriormente, alargam a própria noção do Estado neste contexto, bem como de suas iniciativas neste ramo para além da mera prestação de serviços digitais ou da disponibilização 
de dados governamentais por meios eletrônicos. Como apontam Guimarães e Medeiros (2005):

\begin{abstract}
A essa face de prestação eletrônica de serviços do e-governo devem ser agregados, ainda, outros componentes, como a governança eletrônica, que pode ser entendida como a 'união dos cidadãos, pessoas-chave e representantes legais para participarem das comunidades, junto ao governo, por meios eletrônicos' (FERGUSON, 2002, p. 104 apud GUIMARÃES; MEDEIROS, 2005, p.1)
\end{abstract}

Em outras palavras, como bem observa Vaz (2005, p. 1), "um campo novo de conflito e disputas sociais se estabelece, com a emergência da idéia de governança eletrônica". Em debate estariam as distintas formas de utilização das ferramentas digitais e da internet pelos governos para incrementar a participação da sociedade e dos cidadãos. Ruediger (2002) também aborda as distinções entre governo eletrônico e governança eletrônica, defendendo "a politização do governo eletrônico, transformando-o em governança". Como analisam Guimarães e Medeiros (2005):

Esse autor [Ruediger] exalta a necessidade de que os programas de governo
eletrônico se abram à participação dos demais atores da sociedade, a fim de
transformar 'os mecanismos de serviços ad hoc de governo eletrônico em
mecanismos políticos e sistêmicos de governança' (RUEDIGER, 2002, p. 22).
(GUIMARÃES; MEDEIROS, 2005, p. 5).

A governança eletrônica, ou e-governança, seria o modo como a Internet pode melhorar a capacidade do Estado de governar, e é definida pelas Nações Unidas como:

A utilização pelo setor público de tecnologias de informação e comunicação inovadoras, como a Internet, para ofertar aos cidadãos serviços de qualidade, informação confiável e mais conhecimento, de modo a facilitar o acesso aos processos de governo e encorajar a participação do cidadão. É um comprometimento inequívoco dos tomadores de decisão [governamentais] em estreitar as parcerias entre o cidadão comum e o setor público. (NAÇÕES UNIDAS, 2002, p. 54)

Este conceito parte da ideia de governança, que se refere ao exercício de autoridade política, econômica e administrativa, incluindo a articulação da sociedade e dos atores sociais. Melo (1996, apud GUIMARÃES; MEDEIROS, 2005, p. 4) relaciona a temática da reforma do Estado com o conceito de governança e faz uma ampla análise sobre as diversas possibilidades de definição:

Distinta da governabilidade - conceituada por esse autor como "as condições sistêmicas de exercício do poder em um sistema político" (MELO, 1996, p. 68-69) -, a governança implicaria o modo de uso da autoridade política e estaria relacionada à "capacidade governamental de criar e assegurar a prevalência - ou seja, a capacidade de enforcement - de regras universalistas nas transações sociais, políticosociais e econômicas" (MELO, 1996, p. 69 apud GUIMARÃES; MEDEIROS, 2005, p. 4) 
Ou seja, a ênfase passa a estar na importância do relacionamento entre governo e cidadãos para que o primeiro alcance seus objetivos e implementar políticas. Cunha e Miranda (2013, p. 547) enfatizam como "o conceito de e-governança pode e deve incluir a melhoria da eficiência e eficácia, mas a elas não se resume, é o exercício de uma nova forma e possibilidade de governar, com a participação de uma ampla rede de atores" e explicam:

\begin{abstract}
A aplicação das tecnologias de informação e comunicação para uma melhor governança, a e-governança, tem então como áreas: a e-administração pública, melhoria dos processos governamentais e do trabalho interno do setor público com a utilização das tecnologias de informação e comunicação; e-serviços públicos, melhoria na prestação de serviços ao cidadão e; a e- democracia, maior participação do cidadão, mais ativa, possibilitada pelo uso das tecnologias de informação e comunicação no processo democrático. (CUNHA; MIRANDA, 2013, p. 546)
\end{abstract}

Vaz (2005) complementa esta visão, apontando a necessidade de se considerar o uso das TICs pelos governos como peça importante da "modernização administrativa", o que no Brasil costumeiramente ocorreria como modernizações conservadoras e autoritárias, ou seja, sem implicar democratização dos recursos de poder ou a garantia dos direitos de cidadania. Segundo o autor:

\begin{abstract}
A tarefa aqui é pressionar para que as estratégias governamentais no campo das TIC promovam um processo de modernização democrática da administração pública, afastando os riscos de uma modernização conservadora e autoritária como a que tradicionalmente veio sendo praticada no Brasil. O que se pretende é uma modernização da administração pública que transforme as relações entre Estado e sociedade e vincule a eficácia e a eficiência das ações de governo à afirmação de direitos coletivos de cidadania. (VAZ, 2005, p. 17)
\end{abstract}

Cada vez mais o debate passa a discutir novas visões sobre o Estado em sua relação com a sociedade a partir da internet e das tecnologias digitais, e o que caracterizaria este Estado virtual, como conceitua Fountain (2005):

“O Estado virtual é intersector, interagência e intergovernamental, e a comunicabilidade é conseguida através de estandardização, racionalização e interdependência entre sistemas" (FOUNTAIN, 2005, p. 167).

Em outras palavras, justamente as relações entre o setor público, o setor privado, as organizações sem fins lucrativos e os cidadãos marcam o Estado virtual. E da mesma forma como acontece no campo da e-democracia (entre otimistas, pessimistas e moderados), certamente há distintas visões sobre este relacionamento no que diz respeito à e-governança. Sem exaurir este debate - que deve nortear os próximos esforços de revisão bibliográfica Vaz (2017, p. 91) apresenta o que seria uma "segunda geração de governança eletrônica". Em primeiro lugar, esta nova geração buscaria superar as iniciativas de mão única, ou 
unidirecionais, nas quais o governo utiliza tecnologias que servem como sondas, extraindo dados e informações da sociedade (quando são tecnologias de participação), ou apenas disponibilizando dados e ampliando seu consumo por parte da sociedade:

Entretanto, boa parte da aplicação das TICs ocorre dentro do marco das práticas tradicionais de uso da tecnologia para a participação, transparência e controle social que, construídas ao longo dos últimos vinte anos, encontram-se subordinadas a um modo broadcasting de governança eletrônica, onde predomina a utilização de recursos tecnológicos em mão única (VAZ, 2017, p. 54).

Para Vaz (2017), o "modo broadcasting" seria "uma maneira de organizar o uso dos recursos digitais como recursos secundários ou complementares" às iniciativas tradicionais de relacionamento entre governos e sociedade, mantendo a dinâmica de serem "os agentes estatais que estabelecem os momentos, formatos e conteúdo dos processos participativos e de controle social" (VAZ, 2017, p. 89). Ou seja, deste modo o Estado mantém o controle sobre os recursos e dados oferecidos, bem como sua abrangência. Superar o modo broadcasting de governança eletrônica estaria exatamente em substituir o "monopólio do Estado sobre as decisões e iniciativas de transparência e participação nas políticas públicas" (VAZ, 2017, p. 94). Neste cenário, práticas de desenvolvimento compartilhado de tecnologias e disponibilização dos dados governamentais em formatos abertos (que permite o reuso) abrem um campo de coprodução, de produção descentralizada de aplicações e serviços de base tecnológica e de adoção de tecnologias cívicas por parte do Estado.

De maneira geral, os autores mencionados parecem concordar sobre esta politização do conceito de governo eletrônico (e-gov), que caracterizaria a transição do debate para o conceito de e-governança. No entanto, certa polissemia pode ser encontrada, especialmente para conseguir diferenciar entre e-democracia e e-governança. Para Cunha e Miranda (2013), por exemplo, governança eletrônica é o conceito que abarca e-administração, e-serviços e edemocracia. Para Vaz (2017), governança eletrônica assume um caráter mais próximo do próprio conceito de e-democracia.

Esta pesquisa considera que o campo de debate sobre governança eletrônica abarca as discussões sobre e-administração, e-serviços públicos e sobre e-democracia (CUNHA; MIRANDA, 2013), ao mesmo tempo em que enseja novas questões e abordagens, que vêm sendo estruturadas recentemente em torno do debate sobre governança eletrônica, que se caracterizaria justamente pela abordagem relacional e para o envolvimento dos atores e grupos sociais na coprodução das políticas e serviços públicos, bem como de suas tecnologias digitais. 
Inicialmente a revisão buscou compreender o governo eletrônico e o uso das TICs na administração pública, fenômeno que conceitualmente se estrutura em torno do conceito mais amplo de governo eletrônico, que enfatiza a administração pública e os serviços, e que na concepção de Cunha e Miranda (2013) poderia ser apresentado como e-administração pública e e-serviços públicos. Esta revisão também evidenciou uma mudança de perspectiva no debate, daquela que enfatizava o e-gov para outra que enfatiza aspectos democráticos e de participação, conhecida como e-democracia. Na primeira, a ênfase estaria na busca pela eficiência e melhoria de serviços e maior transparência e publicidade dos atos e decisões (DINIZ, V. 2005; DINIZ, E et al., 2009; MACHADO, 2010; PINHO, 2008). Para ela, o cidadão era cliente, consumidor dos serviços e políticas. Já na perspectiva da e-democracia, o cidadão não é apenas cliente mas, a partir das possibilidades apresentadas pela internet e pelas TICs, pode ser participante deliberando políticas e serviços. Aqui, a ênfase está nos processos participativos de desenho, implementação e monitoramento dos serviços e das políticas públicas (COLOMBO, 2006; CUNHA, 2005; PEIXOTO, 2010; RIBEIRO, 2012).

Além destas duas concepções, mais recentemente o debate começa a constituir um terceiro conceito, de e-governança, que para alguns autores passa a englobar os dois anteriores e dá ênfase para o papel da sociedade na produção de serviços e políticas em conjunto com o Estado, assumindo uma perspectiva mais relacional. Além disso, também procura uma visão menos restrita aos aspectos técnicos ou tecnológicos e que compreende a dimensão organizacional, buscando incorporar a análise sob a ótica da administração pública (CUNHA; MIRANDA, 2013; FOUNTAIN, 2005; GUIMARÃES; MEDEIROS, 2005; VAZ, 2005). Estas distintas compreensões estão apresentadas na figura abaixo:

Figura 1 - Conceitos de E-Gov, E-Democracia e E-Governança no debate sobre o Estado e TICs 


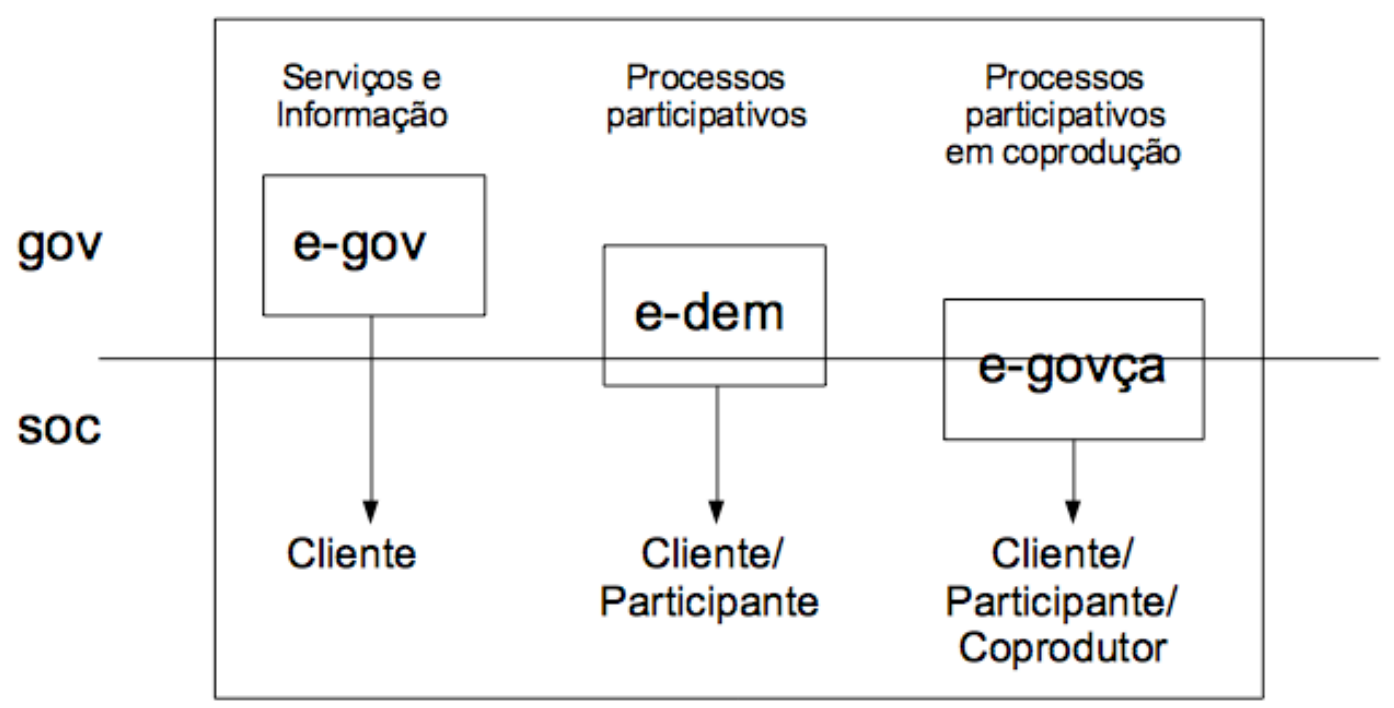

Fonte: Henrique Carlos Parra Parra Filho, 2018

Esta terceira abordagem é a mais apropriada para investigar quais capacidades estatais são desenvolvidas ou mobilizadas em situações nas quais o Estado coproduz tecnologias digitais de participação, ou seja, nas quais há uma participação direta de grupos sociais ou cidadãos na produção da tecnologia, ou a associação formal entre a burocracia estatal e os cidadãos. Além disso, a abordagem relacional deste conceito vai de encontro com o conceito de capacidades estatais escolhido pela pesquisa.

Tal visão começou a ganhar corpo com experiências como a consulta do Marco Civil da Internet e as inovações produzidas pelo Ministério da Cultura, pela Secretaria Geral da Presidência da República e pelo Ministério da Justiça, e que recentemente se institucionalizou na Estratégia de Governança Digital, política que define Governança Digital como

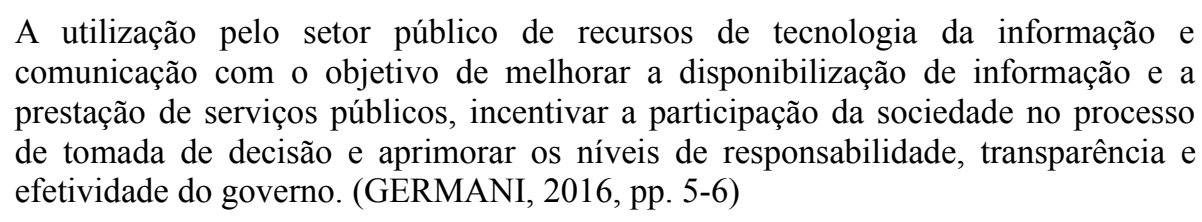

A Estratégia de Governança Digital ${ }^{5}$, que substitui os comitês instituídos no início dos anos 2000 para conduzir as diretrizes e normas de governo eletrônico, demarca a reinterpretação sobre o modo com que as políticas públicas são produzidas e entregues aos usuários. Cada vez mais este processo é visto como produto da negociação entre os participantes e coproduzidos por Estado e sociedade, usuários e comunidades, a partir de uma visão na qual o cidadão deixa o polo passivo e se torna partícipe da construção de políticas

\footnotetext{
${ }_{5}^{5}$ Minuta da Estratégia de Governança Digital da Administração Pública Federal 2016-16. Disponível em: $<$ http://www.sisp.gov.br/egd/wiki/download/file/Minuta_EGD>. Acesso em 16/01/2016.
} 
públicas. Ou seja, a utilização pelo setor público de TICs passa a se referir ao modo como a Internet pode melhorar a capacidade do Estado de governar e formular suas políticas (NAÇÕES UNIDAS, 2002, p. 54); e, como dizem Guimarães e Medeiros (2005, p. 5), passa a conter "um comprometimento inequívoco dos tomadores de decisão [governamentais] em estreitar as parcerias entre o cidadão comum e o setor público”.

Agora, as dicotomias "produtor-usuário" e "emissor-receptor" estariam reduzidas e, como afirma Vaz (2017, p. 96), "o grau de interatividade traz fluidez aos limites entre produção e consumo dos artefatos que se constituem instrumentos de gestão democrática". Da mesma forma, agora tais artefatos estariam em permanente construção social, graças à "adição de valor e trabalho tanto por aquele que produz o artefato (o desenvolvedor do aplicativo) quanto por seu usuário" (VAZ, 2017, p. 96).

\subsubsection{Coprodução}

A participação de novos atores no processo de construção dos artefatos estatais ou de natureza pública e a reconfiguração destes processos de produção são objeto de intenso debate pela literatura. Uma das principais autoras deste debate sobre coprodução, Elionor Ostrom (1996, p.1073) compreende a coprodução como "o processo por meio do qual os recursos usados para produzir um produto ou um serviço são contribuições de indivíduos que não estão na mesma organização". Para ela o sucesso deste tipo de processo estaria na sinergia e na colaboração entre governo e cidadãos.

Esta ideia de que "não apenas o consumo, mas também a produção dos serviços públicos podem requerer participação de cidadãos”, segundo Gabriela Lotta (2017, p. 9), foi pioneiramente pontuada por Ostrom em 1977 e se tornou objeto central de inúmeros autores e de grande parte da literatura:

\footnotetext{
A ideia original era fundamental, mas relativamente simples: que não apenas o consumo, mas também a produção dos serviços públicos podem requerer participação de cidadãos" (tradução nossa) (Ostrom; Ostrom, 1977; Ostrom et al., 1978; Parks et al, 1981; Percy, 1978). Essa definição, pioneiramente pontuada por Elinor Ostrom, é objeto central das discussões de conceito de vários autores (Brandsen; Pestoff; Verschuere, 2013; Pestoff, 2012; Aligica; Tarko, 2013; Alford, 2009; Alford, 2014). (LOTTA, 2017, pp. 9-10)
}

Cabe ainda ressaltar o que, para John Alford (2009), seria um equívoco na compreensão do conceito. Para este autor, o conceito "não significa repassar para cidadãos tarefas que deveriam ser feitas pelo Estado, mas sim potencializar a provisão a partir de atores 
externos". Assim, o processo não deve estar limitado apenas ao momento da "decisão conjunta entre governo e ator não estatal" (LOTTA, 2017, p. 11). O autor também destaca a ênfase dada pela literatura na análise da produção de serviços, em detrimento da análise sobre a produção de bens. Lotta (2017) destaca como a literatura vem alargando os debates, em especial a compreensão sobre os atores envolvidos na coprodução para além do usuário:

No entanto, numa lógica de ampliação das práticas de governança, a literatura mais contemporânea vem demonstrando a participação crescente de outros atores no processo de construção conjunta, como os próprios fornecedores, parceiros, outras organizações, diferentes governos em contextos federativos, sociedade civil organizada etc. (LOTTA, 2017, p. 13)

Chaebo e Medeiros (2017, p. 617) realizaram uma revisão ampla desta literatura e apontam a coprodução como sendo o "relacionamento cooperativo entre profissionais e usuários dos serviços públicos na produção da política pública", em processos nos quais os cidadãos têm papel ativo. Também ressaltam como a literatura de coprodução enfatiza a importância desse novo tipo de processo para a efetividade das políticas e para a viabilização de atividades:

Por coprodução entende-se o relacionamento cooperativo entre profissionais e usuários dos serviços públicos na produção da política pública (PARKS, BAKER, KISER et al., 1981; DELEON e DELEON, 2002; OSTROM, 1996; BOVAIRD, VAN RYZIN, LOEFFLER et al., 2015; RANTAMAKI, 2017), no qual, sem a participação ativa desses usuários, os objetivos de política pública não poderiam ser efetivamente alcançados (PARKS, BAKER, KISER et al., 1981; ALFORD, 1998; RYAN, 2012; BOVAIRD, VAN RYZIN, LOEFFLER et al., 2015). Nas palavras de Alford (1998, p. 129, tradução nossa), "a coprodução não é meramente uma coisa boa como ajuda voluntária. Sem ela, na realidade, muitas atividades se tornam impossíveis". (CHAEBO; MEDEIROS, 2017, p. 3)

Os autores sistematizam os principais conceitos presentes na literatura de coprodução e oferecem uma base conceitual importante como referência a novas investigações e pesquisas:

Quadro 4 - Conceitos da literatura de Coprodução

(continua)

\begin{tabular}{|l|l|l|}
\hline Conceitos & Descrição dos conceitos & Principais autores \\
\hline $\begin{array}{l}\text { Participantes da } \\
\text { coprodução }\end{array}$ & $\begin{array}{l}\text { Relação de coprodução é estruturada } \\
\text { fundamentalmente sobre o relacionamento entre } \\
\text { produtores regulares (profissionais) e consumidores } \\
\text { regulares (usuários) dos serviços. Soma-se a esses } \\
\text { participantes a presença de cidadãos e voluntários. }\end{array}$ & $\begin{array}{l}\text { Parks, Baker, Kiser et al. } \\
\text { (1981), Ostrom (1996) e } \\
\text { Alford (2002) }\end{array}$ \\
\hline $\begin{array}{l}\text { Motivações à } \\
\text { coprodução }\end{array}$ & $\begin{array}{l}\text { Participantes da coprodução precisam estar } \\
\text { motivados para contribuir com seu tempo e esforço. } \\
\text { Diferentes tipos de participantes apresentam }\end{array}$ & $\begin{array}{l}\text { Kiser e Percy (1980) e Alford } \\
(2002,2014)\end{array}$ \\
\hline
\end{tabular}




\begin{tabular}{|c|c|c|}
\hline & diferentes tipos de motivação. & \\
\hline Nível da coprodução & $\begin{array}{l}\text { Coprodução pode ocorrer em } 3 \text { níveis, dependendo } \\
\text { do alcance dos esforços e benefícios pretendidos } \\
\text { pelos usuários: coprodução individual, coprodução } \\
\text { grupal e coprodução coletiva. }\end{array}$ & $\begin{array}{l}\text { Brudney e England (1983), } \\
\text { Pestoff (2014) e Bovaird, } \\
\text { Van Ryzin, Loeffler et al. } \\
(2015)\end{array}$ \\
\hline Formas de coprodução & $\begin{array}{l}\text { A forma em que são ajustadas as demandas dos } \\
\text { usuários e os procedimentos dos profissionais. Três } \\
\text { formas de coprodução podem ocorrer: (1) novos } \\
\text { entendimento das demandas dos usuários, levando à } \\
\text { reformulação de procedimentos pelos profissionais; } \\
\text { (2) usuários apoiando as ações propostas pelo } \\
\text { governo; e (3) ajuste mútuo a respeito das atividades } \\
\text { entre usuários e profissionais para a coprodução das } \\
\text { políticas. }\end{array}$ & $\begin{array}{l}\text { Whitaker (1980) e Ostrom } \\
(1996)\end{array}$ \\
\hline Papel do governo & $\begin{array}{l}\text { Além de atuar como produtor, regulador e provedor } \\
\text { de subsídios, o governo tem o papel de induzir os } \\
\text { usuários a se engajarem nas ações de coprodução. }\end{array}$ & Lam (1996) e Alford (1998) \\
\hline Arranjos institucionais & $\begin{array}{l}\text { Os sistemas de regras que definem as competências } \\
\text { dos profissionais orientam as formas de interação } \\
\text { com os usuários, estabelecem os inputs necessários e, } \\
\text { ainda, podem facilitar ou reprimir o relacionamento } \\
\text { da coprodução. }\end{array}$ & $\begin{array}{l}\text { Parks, Baker, Kiser et al. } \\
(1981), \text { Lam (1996) e } \\
\text { Verschuere, Brandson e } \\
\text { Pestoff (2012) }\end{array}$ \\
\hline Capacidade técnica & $\begin{array}{l}\text { O grau de complementaridade entre os esforços de } \\
\text { profissionais e usuários, sendo a interdependência } \\
\text { desses esforços necessária para caracterizar as ações } \\
\text { como de coprodução. }\end{array}$ & $\begin{array}{l}\text { Parks, Baker, Kiser et al. } \\
\text { (1981) e Ostrom (1996) }\end{array}$ \\
\hline Viabilidade econômica & $\begin{array}{l}\text { O grau de eficiência da relação de coprodução, em } \\
\text { que os esforços coprodutivos se apresentam como a } \\
\text { alternativa com menor custo de implementação. }\end{array}$ & $\begin{array}{l}\text { Parks, Baker, Kiser et al. } \\
\text { (1981) e Ostrom (1996) }\end{array}$ \\
\hline Aspectos democráticos & $\begin{array}{l}\text { Capacidade dos cidadãos influenciarem nos rumos da } \\
\text { política pública, não atuando apenas como executores } \\
\text { das atividades que o poder público indica. }\end{array}$ & $\begin{array}{l}\text { Vanleene, Verschuere e Voets } \\
\text { (2016) e Rantamaki (2017 }\end{array}$ \\
\hline
\end{tabular}

Fonte: Gemael Chaebo e Janann Joslin Medeiros, 2017, p. 10

Por fim, antes de apresentar como alguns destes autores entendem os tipos de coprodução e realizar uma breve sistematização sobre suas visões, cabe destacar o conceito de coprodução para José Francisco Salm e Maria Ester Menegasso (2008, 2010). Para eles, “coprodução é uma estratégia para a produção dos serviços públicos por meio do compartilhamento de responsabilidades e poder entre agentes públicos, agentes privados e cidadãos" (SALM; MENEGASSO, 2010, p. 1). Seria então a participação dos cidadãos em todo o processo de produção de políticas (elaboração, desenho, implementação e avaliação), com o objetivo de construção do bem comum. Como vimos, há uma ideia central do conceito de coprodução, ou seja, que aprodução dos serviços públicos podem requerer participação de cidadãos, que tem se estabelecido como linha de força da literatura. 
Além de resgatar os principais conceitos, é importante analisar os tipos de coprodução que a literatura destaca. Gordon Whitaker (1980) apresenta uma tipologia entendendo que o cidadão pode coproduzir os serviços por solicitação, assistência na provisão ou por ajuste mútuo com o governo. Segundo Salm e Menegasso (2010, p. 11), esse é um dos trabalhos "mais citados quando se trata do tema da coprodução [...], o primeiro autor a formular tipologias de coprodução, publicadas em revista de larga circulação".

Three broad types of activities constitute coproduction: (1) citizens requesting assistance from public agents; (2) citizens providing assistance to public agents; and (3) citizens and agents interacting to adjust each other's service expectations and actions. (WHITAKER, 1980, pp. 242-244)

No primeiro tipo, os usuários pedem auxílio aos profissionais do órgão provedor que, ao darem resposta a estas demandas, aprimoram seus procedimentos e o serviço. No segundo, haveria assistência por parte dos usuários aos profissionais durante a execução de algumas de suas tarefas. Já no tipo de ajuste mútuo, usuários e profissionais estabeleceriam entendimento comum do problema e acordo sobre a intervenção de cada participante:

$[\ldots]$ both the citizen and the agent share responsibility for deciding what action to take. Moreover, each accords legitimacy to the responsibility of the other. The citizen coproducer is not a "client" in the sense that he or she is not a supplicant seeking the favor of the agent. (WHITAKER, 1980, pp. 242-244)

Voorberg, Bekkers e Tummers (2013) seguem em uma direção similar, coincidentemente apresentando três tipos de coprodução. No primeiro, os cidadãos complementariam a política pública. No segundo, seriam co-designers, atuando no desenho da política. Por fim, haveria um terceiro tipo, quando os cidadãos co-iniciariam as políticas com o governo. Segundo os autores, o primeiro tipo seria o mais frequente. Eles descrevem o modelo assim:

We distinguished three different levels of participation: Level 1 involves the citizen just as co-implementer of the public service. In these examples citizen involvement has already been defined by the public service. For instance Benari (1990) described the need for participation of citizens in garbage disposal services. In order to effectively divide garbage, assistance of citizens is required to already divide garbage at their homes. Level 2 approaches the citizen as co-designer of how the product or service should be delivered. In most case the initiative for the co-creation lies with the public institution, but citizens decide how the service is being delivered. A typical example of 'level 2 participation' is given by Wipf et al. (2009) who described how citizens in France participated in the design and maintaining of outdoor recreation. Citizens got to codecide how the outdoor recreation was being designed, after the invitation of the municipalities. The third level represents the citizen as initiator and the government as supporting (or frustrating) actor. A remarkable example of this kind of participation is delivered by Rossi (2004) who described that because of civil initiative, the historical center of Naples reopened for the public and the monuments were restored. (VOORBERG; BEKKERS; TUMMERS, 2013, pp. 9-10) 
Salm e Menegasso (2010) também empreendem um esforço de propor uma tipologia, a partir de uma síntese das tipologias de participação e das propostas dos autores mais citados da literatura de coprodução. O resultado, para eles, seriam cinco modelos distintos de coprodução: nominal, simbólico, funcional, representativo com sustentabilidade e o de mobilização comunitária.

Segundo os autores, no modelo nominal (BJUR; SIEGEL, 1977; KISER; PERCY, 1980; SUNDEEN, 1985) não haveria poder do cidadão sobre o Estado (SALM; MENEGASSO, 2010, p. 13), configurando uma estratégia para a produção dos serviços públicos com o propósito, apenas, de torná-los mais eficientes, o que seria feito por meio do compartilhamento de responsabilidades entre a comunidade, preferencialmente de maneira voluntária, e o Estado.

O modelo simbólico teria, quase sempre, "um caráter manipulativo e serve para demonstrar a presença do estado" (SALM; MENEGASSO, 2010, p. 14), podendo ocorrer inclusive em Estados não-democráticos. Um terceiro modelo, o de coprodução funcional, seria uma estratégia utilizada para produzir os serviços públicos de maneira mais eficiente e eficaz (foco em resultados e menor custo) com a participação de indivíduos ou da coletividade. Ocorreria "por meio da solicitação dos serviços, de assistência ao estado ou por um ajuste mútuo com o estado". Os principais autores que o compõem são Whitaker (1980), Brudney e England (1983) Schneider (1986) e Alford (2002), segundo Salm e Menegasso (2010, p. 14).

Já no modelo chamado como coprodução "representativa com sustentabilidade" haveria delegação de poder pelo Estado. Ele seria o resultado da sinergia que se estabelece na realização dos serviços públicos de que participam os cidadãos, as organizações sociais e o aparato administrativo estatal, todos interagindo em prol do bem comum. Para Salm e Menegasso (2010, p. 14), “os autores que com ele se alinham são Levine (1984), Ostrom (1996), Marshall (2004) e Bovaird (2007)".

Haveria um último modelo, chamado pelos autores de "coprodução para a mobilização comunitária", no qual "os serviços públicos são coproduzidos como uma estratégia para a permanente mobilização da comunidade e de superação da organização burocrática" (SALM; MENEGASSO, 2010). Transformativo, buscaria reconfigurar a comunidade e o Estado e estaria orientado por princípios éticos e pela democracia normativa. Para Salm e Menegasso 
(2010, p. 14), "Defendem esse modelo os autores Mitlin (2008), Rosentraub e Sharp (1981) e Cooper e Kathi (2005)".

Quadro 5 - Modelos de Coprodução para Salm e Menegasso

\begin{tabular}{|c|c|c|}
\hline Modelo & Descrição & Autores \\
\hline Nominal & $\begin{array}{l}\text { Não haveria poder do cidadão sobre o } \\
\text { Estado, configurando uma estratégia para a } \\
\text { produção dos serviços públicos com o } \\
\text { propósito, apenas, de torná-lo mais } \\
\text { eficientes. }\end{array}$ & $\begin{array}{l}\text { Bjur e Siegel (1977); Kiser e Percy } \\
\text { (1980); Sundeen (1985) }\end{array}$ \\
\hline Simbólica & $\begin{array}{l}\text { Teria, quase sempre, um caráter manipulativo } \\
\text { e serve para demonstrar a presença do estado, } \\
\text { podendo ocorrer inclusive em estados não } \\
\text { democráticos. }\end{array}$ & $\begin{array}{l}\text { A literatura disponível não se refere } \\
\text { a suas características, contudo, ele } \\
\text { pode estar presente na realidade. }\end{array}$ \\
\hline Funcional & $\begin{array}{l}\text { Ocorreria por meio da solicitação dos } \\
\text { serviços, de assistência ao estado ou por um } \\
\text { ajuste mútuo com o estado para produzir os } \\
\text { serviços públicos de maneira mais eficiente e } \\
\text { eficaz. }\end{array}$ & $\begin{array}{l}\text { Whitaker (1980); Brudney e } \\
\text { England (1983); Schneider (1986); } \\
\text { e Alford (2002) }\end{array}$ \\
\hline $\begin{array}{l}\text { Representativa com } \\
\text { sustentabilidade }\end{array}$ & $\begin{array}{l}\text { Resultado da sinergia que se estabelece na } \\
\text { realização dos serviços públicos de que } \\
\text { participam os cidadãos, as organizações } \\
\text { sociais e o aparato administrativo estatal, } \\
\text { todos interagindo em prol do bem comum. }\end{array}$ & $\begin{array}{l}\text { Levine (1984); Ostrom (1996); } \\
\text { Marshall (2004); e Bovaird (2007) }\end{array}$ \\
\hline Mobilização comunitária & $\begin{array}{l}\text { Os serviços públicos são coproduzidos como } \\
\text { uma estratégia para a permanente } \\
\text { mobilização da comunidade e de superação } \\
\text { da organização burocrática. }\end{array}$ & $\begin{array}{l}\text { Mitlin (2008); Rosentraub e Sharp } \\
\text { (1981); e Cooper e Kathi (2005) }\end{array}$ \\
\hline
\end{tabular}

Fonte: Henrique Carlos Parra Parra Filho, 2018

Assim como Ostrom (1996) e boa parte do campo, esta investigação entende coprodução como "o processo por meio do qual os recursos usados para produzir um produto ou um serviço são contribuições de indivíduos que não estão na mesma organização". Não será objeto desta pesquisa o debate sobre estes conceitos, mas apenas o uso do conceito de Ostrom para, quando da análise do objeto, caracterizar e identificar a coprodução.

As tipologias estudadas neste capítulo oferecem uma referência conceitual importante, embora não constituam referencial metodológico em nenhum momento para esta investigação. Ainda que o estudo de um software que tem sido desenvolvido e utilizado há anos pela Administração Pública Federal - como veremos no Capítulo 4 - possibilite uma abordagem do software enquanto um bem, não será objeto dessa pesquisa aprofundar esta questão, nem mesmo adotar qualquer uma das tipologias identificadas na literatura. 
Menos do que enquadrar nosso objeto em um destes tipos ideias, o estudo destas tipologias aponta como a literatura de coprodução vem se preocupando cada vez mais com o estudo de fenômenos que envolvem a participação da sociedade e de indivíduos na produção de políticas públicas com o Estado, através de relações mais horizontais, de ajuste mútuo, nas quais o cidadão desenha e formula conjuntamente, através de intensa negociação e mantendo poder real de controle e intervenção.

Ademais, com tamanho (e crescente) protagonismo da sociedade na produção de políticas públicas graças ao desenvolvimento das novas tecnologias, investigar de que forma técnicas de poder (novos sistemas de informação e softwares) são desenvolvidas pela sociedade e incorporados pelo Estado de modo a configurar seu próprio poder infraestrutural - ou suas capacidades estatais - parece ser um tema ainda pouco explorado e extremamente relevante. Jane Fountain (2005) é precisa:

Um enfoque exclusivamente centrado na capacidade tecnológica e nos sistemas de
informação, negligenciaria a interdependência entre as organizações e os sistemas
tecnológicos. As tecnologias de informação e comunicação estão misturadas de
forma homogénea e trabalham dentro e através das organizações. Por esta razão, é
imperativo entender as estruturas organizacionais, os processos e as mudanças
culturais e organizacionais, para perceber e possivelmente influenciar, o uso da
tecnologia na governação. (FOUNTAIN, 2005, p. 149)

Uma abordagem institucional (que esta pesquisa pretende ao enfocar as capacidades estatais) oferece um caminho útil, já que os representantes dos governos e a burocracia, através de processos de tomada de decisão, produzem decisões e ações que resultam ou efetivam um Estado em rede. Fountain (2005) resume assim a importância de se adotar uma abordagem institucional e centrar foco no estudo da administração pública neste campo de debate:

Ao invés das mudanças ocorrerem à «velocidade da Internet», usando uma expressão muito popular nos anos 90, os governos mudam muito lentamente. Este facto não se deve à falta de mecanismos de mercado, que poderiam criar soluções mais ou menos competitivas, deve-se essencialmente à complexidade burocrática dos governos, às tarefas inerentes ao seu funcionamento e à importância de questões que urgem ser debatidas e resolvidas, nomeadamente, a responsabilização, jurisdição, distribuição de poder e equidade. (FOUNTAIN, 2005, p. 150)

Sem o objetivo de exaurir o debate sobre o uso de TICs por governos ou mesmo adentrar o intenso debate conceitual que marca as discussões sobre governo e governança eletrônica ou mesmo sobre coprodução, esta pesquisa vai se valer do conceito de governança digital, presente na recente Estratégia de Governança Digital publicada pelo Executivo Federal. Faz isso ao constatar que a ênfase na ideia de governança está presente na literatura 
(GUIMARÃES; MEDEIROS, 2005; CUNHA; MIRANDA, 2013; GERMANI, 2016; VAZ, 2017;), mesmo que com distinções semânticas; e por entender que o conceito de governança digital enfatiza explicitamente a participação social na produção de tecnologias governamentais (coprodução), sendo mais apropriado para o objeto e as questões desta pesquisa.

O esforço de revisão realizado neste capítulo possibilitou uma maior compreensão do que é uma Conferência Nacional enquanto fenômeno político e ter uma aproximação sobre o debate que a literatura faz atualmente sobre as possibilidades do uso de TICs para inclusão de novos sujeitos. Também foi extremamente necessário para recuperar uma parte do debate sobre e-democracia e e-participação e as discussões sobre as transformações que TICs podem promover na estrutura da Sociedade e, consequentemente, no próprio Estado. Aqui, a revisão sobre os conceitos de governo eletrônico, governança eletrônica e do conceito de governança digital - este bastante recente - contribuíram com elementos necessários para a compreensão do objeto desta pesquisa, mas além disso, para compreender com mais clareza como o referencial de capacidades estatais se adéqua ao objeto e à questão de pesquisa.

Como vimos, o debate na literatura de TICs e Governo caminha progressivamente de uma abordagem mais restrita à burocracia e ao uso da tecnologia para maior eficiência nas atividades burocráticas e para uma ênfase relacional, que ressalta cada vez mais o papel da sociedade em participar de tais atividades e o uso das tecnologias na reconfiguração do próprio Estado, possibilitando novos arranjos e fortalecendo a governança, ou a capacidade estatal em se relacionar com atores da sociedade para atingir seus objetivos e efetivar suas ações.

Assumindo o pressuposto teórico, a partir da literatura, de que existem capacidades estatais específicas para a ação do Estado na coprodução de tecnologias de participação social, consideraram-se tais capacidades em quatro dimensões: institucional, política, administrativa e técnica (GRINDLE, 1996). O debate sobre capacidades estatais no Brasil têm enfatizado cada vez mais o contexto democrático, reconhecendo as múltiplas formas de interações entre Estado e Sociedade e investigando as capacidades estatais necessárias e as demandadas nestas relações e suas implicações. (GOMIDE; PIRES, 2012, 2014; PEREIRA, 2014; STEFANI, 2015; BICHIR, 2016; SOUZA, 2016). Esta pesquisa também assume que quaisquer processos de participação exigem capacidades de gestão por parte dos governos (COLOMBO, 2006; PIRES, 2012; CUNHA et al, 2015; STEFANI, 2015; SOUZA, 2016). 
Entendemos, por fim, que o envolvimento da sociedade se alarga da participação em processos para a coprodução dos meios utilizados para a própria participação. No caso dos processos participativos usando TIC, isso significa falar de coprodução de tecnologias e da possibilidade de as capacidades necessárias para processos deste tipo serem geradas ou mobilizadas pelo Estado, a depender das necessidades existentes. 


\section{Metodologia}

Este capítulo tem como objetivo apresentar a abordagem metodológica adotada pela pesquisa, detalhar o referencial conceitual utilizado e descrever os procedimentos de coleta e análise dos dados, justificando tais escolhas a partir da questão da pesquisa e da fundamentação teórica apresentada no Capítulo 2.

Uma pesquisa é a lógica que vincula os dados coletados e as conclusões tiradas a partir destes dados com as questões iniciais propostas. Esta é a lógica que o presente capítulo buscará apresentar. Dessa forma, sua última seção resume os dados coletados, expondo um panorama mais geral do que foi observado.

\subsection{DimENSÃo TEÓRICA}

Como já foi apresentado, o interesse desta pesquisa está em identificar quais são as capacidades estatais demandadas para a coprodução de TICs de participação e compreender como são mobilizadas, contribuindo com o campo de estudo de capacidades estatais, especialmente aquelas cujos objetos se relacionem com processos de participação mediados por TICs ou processos de desenvolvimento de TICs que envolvam a participação da sociedade.

Revisões de literatura são o esforço de análise dos materiais teóricos e publicações de pesquisa relacionados aos fenômenos a serem estudados pelo pesquisador, de modo a oferecer uma base conceitual para o estudo. A revisão pode ser dividida entre as de tipo sistemática e conceitual. No primeiro tipo, considera-se que houve um esforço para encontrar todos os estudos existentes sobre um determinado objeto ou relação causal. Já as revisões conceituais, como a que foi realizada por esta pesquisa, preocupam-se mais em entender a compreensão de um fenômeno para distintos campos, sem a necessidade de exaurir os estudos existentes. Resume assim Robert Skate (2011): "A sistemática pode proporcionar uma contribuição maior para os pesquisadores em um campo de pesquisa desenvolvido. A conceitual pode proporcionar uma contribuição maior para enxergar a complexidade de um problema profissional" (2011, p. 125).

A revisão de literatura realizada por esta pesquisa, do tipo conceitual, buscou se aprofundar na literatura de capacidades estatais - referencial teórico principal desta 
investigação - e também lançou mão das literaturas que tratam das temáticas de participação social mediada por tecnologias, democracia digital, governo eletrônico e governança digital, suportes importantes para o estudo de nosso objeto, o processo de desenvolvimento do software utilizado na $3^{\text {a }}$ Conferência Nacional de Juventude.

Como já foi detalhado no Capítulo 2, o debate sobre capacidades estatais no Brasil têm enfatizado cada vez mais o contexto democrático e suas implicações, incorporando o estudo sobre arranjos, redes sociais ou governança (GOMIDE; PIRES, 2012, 2014; PEREIRA, 2014; STEFANI, 2015; BICHIR, 2016; SOUZA, 2016). Essa abordagem reconhece as múltiplas formas de interações entre Estado e Sociedade e investiga as capacidades estatais necessárias e demandadas nestas relações.

Tomando a análise das entrevistas e dados apresentados tanto por Clóvis Souza (2016), quanto por Anita Stefani (2015), cujas investigações tratam de processos de participação social mediados por TICs, constata-se a recorrente mobilização de recursos externos à burocracia federal, por meio de consultores especializados, tecnologias de outros órgãos ou da sociedade. Assim, a visão de que as capacidades podem ser constituídas de recursos mobilizados na sociedade em determinados momentos (mesmo que depois se tornem indisponíveis) é um dos pressupostos teóricos desta pesquisa.

Stefani (2015), como vimos no capítulo precedente, mobiliza as literaturas de participação social e de capacidades estatais para desenvolver uma matriz de caracterização das iniciativas governamentais que utilizam TICs em processos de participação e ainda apresentar um conceito específico de capacidade estatal, nomeado de "Capacidade de Governo relacionada à Utilização de TICs em Processos Participativos”, CGTPS. Esta capacidade é composta por onze subcategorias criadas por Stefani (2015), estruturadas em função das quatro categorias de Grindle (1996); e é coerente com os pressupostos e com o objeto desta pesquisa:

Quadro 6 - Categorização de Capacidades de Governo

(continua)

\begin{tabular}{|l|l|}
\hline Categoria & Subcategorias \\
\hline Capacidade Institucional - CGITPS & Institucionalidade do Processo \\
\cline { 2 - 2 } & Pluralidade Institucional do Governo \\
\hline Capacidade Técnica - CGTTPS & Recursos Humanos \\
\cline { 2 - 2 } & Recursos Humanos e Físicos \\
\cline { 2 - 2 } &
\end{tabular}




\begin{tabular}{|l|l|}
\cline { 2 - 2 } & Tecnologia \\
\cline { 2 - 2 } & Gestão do Processo Participativo \\
\hline Capacidade Administrativa - CGATPS & TI na Administração Pública \\
\cline { 2 - 2 } & Locus do Tema no Governo \\
\hline Capacidade Política - CGPTPS & Participação como Método de Governo \\
\cline { 2 - 2 } & Liderança e Condução Política \\
\hline & Comunicação \\
\hline
\end{tabular}

Fonte: Anita Stefani. 2015.

O conceito de Capacidade de governo relacionadas à utilização de TICs em processo de participação social (CGTPS) criado por Stefani (2015), além de ter sido construído a partir do estudo de um fenômeno correlato ao que esta investigação pretende enfocar, também assume a abordagem relacional - destacada pela terceira geração de debate sobre capacidades estatais e tão presente na produção brasileira recente. Pelo fato de esta pesquisa tratar de tecnologias de participação construídas em coprodução, uma abordagem que enfatiza as relações entre Estado e Sociedade é fundamental. Tal conceito de CGTPS desenvolvido pela autora é formado por três pilares teóricos:

- A capacidade de governo é inter-relacional e depende diretamente da governabilidade do sistema e do projeto de governo;

- Os arranjos institucionais que sustentam ações e projetos governamentais influenciam as capacidades de governo disponíveis;

- Há, ao menos, quatro dimensões relevantes de capacidades de governo: institucional, técnica, administrativa e política.

Quadro 7 - Composição teórica do conceito de Capacidade de Governo relacionada ao uso de TICs em processos participativos

(continua)

\begin{tabular}{|l|l|l|l|l|}
\hline Termo & Autor)es) & Definição & $\begin{array}{l}\text { Contribuição ao } \\
\text { conceito de CGTPS }\end{array}$ & Campo de Estudos \\
\hline $\begin{array}{l}\text { Capacidade } \\
\text { de Governo }\end{array}$ & $\begin{array}{l}\text { Matus (1993, } \\
1994,2006)\end{array}$ & $\begin{array}{l}\text { Capacidade de liderança, } \\
\text { condução ou direção } \\
\text { ponderada pela experiência } \\
\text { e os conhecimentos em } \\
\text { ciências e técnicas de } \\
\text { gestão acumulada na } \\
\text { pessoa do líder, em sua } \\
\text { equipe de governo e/ou na } \\
\text { organização que dirige. }\end{array}$ & $\begin{array}{l}\text { A capacidade de governo } \\
\text { énter-relacional, } \\
\text { somente compreensível } \\
\text { no contexto do triângulo } \\
\text { de governo (capacidade } \\
\text { de governo; } \\
\text { governabilidade; e o } \\
\text { projeto de governo) e na } \\
\text { perspectiva do } \\
\text { Planejamento Estratégico }\end{array}$ & $\begin{array}{l}\text { Gestão e Administração } \\
\text { Pública }\end{array}$ \\
\hline
\end{tabular}




\begin{tabular}{|c|c|c|c|c|}
\hline & & & Situacional (PES) & \\
\hline \multirow[t]{2}{*}{$\begin{array}{l}\text { Capacidade } \\
\text { Estatal }\end{array}$} & Grindle (1996) & $\begin{array}{l}\text { Capacidade de definir as } \\
\text { condições para as } \\
\text { interações econômicas e } \\
\text { políticas e para o } \\
\text { desempenho das funções } \\
\text { estatais essenciais. }\end{array}$ & $\begin{array}{l}\text { Quatro categorias } \\
\text { compõem a capacidade } \\
\text { estatal: } \\
\text { - Capacidade institucional } \\
\text { - Capacidade técnica } \\
\text { - Capacidade } \\
\text { administrativa } \\
\text { - Capacidade política }\end{array}$ & $\begin{array}{l}\text { Economia } \\
\text { Relações Internacionais } \\
\text { Ciência Política }\end{array}$ \\
\hline & $\begin{array}{l}\text { Peixoto e } \\
\text { Gomide } \\
(2012,2014)\end{array}$ & $\begin{array}{l}\text { Capacidade pode ser } \\
\text { entendida a partir de dois } \\
\text { componentes: o técnico- } \\
\text { administrativo e o político. } \\
\text { O primeiro contempla as } \\
\text { competências dos agentes } \\
\text { do Estado para levar a } \\
\text { efeito suas políticas, } \\
\text { produzindo ações } \\
\text { coordenadas e orientadas } \\
\text { para a produção de } \\
\text { resultados. O segundo, } \\
\text { refere-se às habilidades da } \\
\text { burocracia em expandir os } \\
\text { canais de interlocução, } \\
\text { negociação com os } \\
\text { diversos atores sociais, } \\
\text { processando conflitos e } \\
\text { prevenindo a captura por } \\
\text { interesses específicos. }\end{array}$ & $\begin{array}{l}\text { A capacidade estatal é } \\
\text { determinada pelos } \\
\text { arranjos institucionais que } \\
\text { dão sustentação à } \\
\text { implementação de } \\
\text { políticas públicas. } \\
\text { Entende-se como arranjo } \\
\text { institucional o conjunto } \\
\text { de regras, mecanismos, e } \\
\text { processos que definem a } \\
\text { forma particular como se } \\
\text { coordenam os atores e } \\
\text { interesses na } \\
\text { implementação de uma } \\
\text { política pública } \\
\text { específica. }\end{array}$ & $\begin{array}{l}\text { Desenvolvimento } \\
\text { Econômico e Social } \\
\text { Políticas Públicas } \\
\text { Economia Aplicada }\end{array}$ \\
\hline
\end{tabular}

Fonte: Anita Stefani, 2015.

Este conceito (CGTPS) articula as principais contribuições teóricas de Matus (1993, 1994, 2006), Gomide e Pires $(2012,2014)$ e Grindle (1996) e parece adequado ao objeto da presente pesquisa e ao caso a ser estudado, dada sua ênfase na relação entre Estado e Sociedade e a na dimensão política.

Stefani (2015) empregou procedimentos de agrupamento e análise dos dados coletados, separando todas as unidades de análise e classificando cada uma delas segundo as quatro dimensões de Grindle (1996). Depois, também analisando a recorrência e o significado de cada unidade, a autora agrupou as unidades em subcategorias:

Tais unidades foram, então, agrupadas de acordo com a capacidade de governo correspondente [...] Dessa forma, cada um dos quatro tipos de capacidades de governo possíveis era composto por várias unidades de análise que representaram subcategorias de capacidades. Dentre as 4 (quatro) categorias propostas para o objetivo da pesquisa, foram identificadas 11 (onze) subcategorias decorrentes da análise de 74 (setenta e quatro) unidades de análise. (STEFANI, 2015, pp. 94-95)

No entanto, como a própria autora assinala, o fato de seu trabalho não ter enfatizado os aspectos funcionais, tecnológicos e de desenho das TICs possibilita reavaliações e 
atualizações. É o que a presente pesquisa buscou enfatizar, em especial para entender mais sobre quais capacidades estatais são importantes em processos de coprodução de tecnologias de participação e de que maneira elas são mobilizadas, com ênfase para as relações entre as distintas capacidades estatais identificadas a partir do estudo do caso de produção das tecnologias utilizadas pela $3^{\text {a }}$. Conferência Naiconal de Juventude.

\subsection{DIMENSÃO SUBSTANTIVA}

Nessa seção debataremos os procedimentos metodológicos utilizados e de que modo se refletiram no esforço e campo realizado. Para comçar, a presente pesquisa adotou o método do estudo de caso interpretativo, dentro da abordagem qualitativa, elegendo o conceito de Capacidade de Governo para Utilização de TICs em Processos de Participação Social (STEFANI, 2015) para pesquisar o processo de coprodução do software utilizado na $3^{\mathrm{a}}$ Conferência Nacional de Juventude. Essa foi a abordagem escolhida a partir da observação de três condições: o tipo de questão de pesquisa proposto; a extensão do controle sobre os eventos; e a contemporaneidade dos eventos estudados.

A questão da pesquisa - quais são e como são mobilizadas as capacidades estatais necessárias à coprodução de TICs governamentais de participação social - tem um caráter mais interpretativo e, ao contrário de questões que buscam descrever a incidência de um fenômeno e sua prevalência ou mesmo prever resultados, esta investigação procura entender os mecanismos operacionais (processos, instrumentos e recursos) que ajudam a moldar a coprodução de tecnologias governamentais de participação.

Arilda Godoy (2006) destaca o uso do método de estudo de caso para questões de pesquisa deste tipo:

Os estudos de caso, no entanto, também pode ser motivados por questões de natureza conceitual, que surgem de teorias previamente estabelecidas, ou que se propõem a elaborar uma teoria a partir de um ou mais casos analisados. São problemas de pesquisa que procuram responder a questões sobre processos ("por que" e "como" as coisas acontecem), assim como as questões de compreensão que procuram descrever e interpretar "o que" aconteceu numa determinada situação. (GODOY, 2006, p. 127)

Sobre a extensão do controle que um pesquisador tem sobre os eventos comportamentais reais, frisamos que ao eleger as capacidades estatais e a coprodução de TICs governamentais de participação (tomando como caso em estudo a $3^{\text {a }}$ Conferência Nacional de Juventude), assumimos a importância de analisar condições contextuais (em especial os 
fatores políticos e de agenda política ${ }^{6}$ que influenciavam a tomada de decisão sobre o uso de tecnologias e de diretrizes destas tecnologias), entendendo ainda a dificuldade de separá-los do próprio fenômeno político a ser estudado, ou seja, o caso concreto da Conferência Nacional. Assim, ao contrário de um experimento, não é possível e nem mesmo interessante separar o fenômeno do contexto, onde se inserem questões como o programa de governo, a governabilidade política e o papel do Conselho Nacional de Juventude, por exemplo.

Lembramos que a $3^{\mathrm{a}}$ Conferência Nacional de Juventude é um fenômeno bastante recente, concluído em dezembro de 2015; e o processo de desenvolvimento de seu software ocorreu concomitante a ele. Dessa forma, uma investigação específica do caso pode contribuir para descrevê-lo com uma quantidade de dados e detalhes maiores, possibilitando entender quais capacidades foram demandadas e como operaram.

Cabe ainda destacar que o caráter inovador - tendo sido a primeira Conferência Nacional que desenvolveu software próprio tanto para a eleição de propostas, quanto de delegados - e ainda pouco investigado do objeto, como explica Godoy (2006), também pode indicar o uso do estudo de caso:

De acordo com Merriam (1988), os pesquisadores geralmente utilizam o estudo de
caso quando desejam compreender uma situação em profundidade, enfatizando seu
significado para os vários envolvidos. [...] Hartley (1995) destaca que o estudo de
caso tem sido amplamente utilizado na área de comportamento organizacional
especialmente quando se quer compreender processos de inovação e mudança
organizacionais a partir da complexa interação entre forças internas e o ambiente
externo. Segundo o autor, o estudo de caso tem permitido rastrear processos de
mudança, identificando e analisando as forças históricas, pressões contextuais e a
dinâmica dos vários grupos de stakeholders na aceitação ou oposição a tais
processos (...). (GODOY, 2006, pp. 119-121)

Desta forma, o método do estudo de caso interpretativo ofereceu as maiores vantagens e se adequou melhor ao objeto desta pesquisa. A investigação qualitativa se diferencia da quantitativa pelos seus objetivos essenciais e pela sua percepção de que o conhecimento é construído pessoalmente, não se tratando portanto de uma "descoberta" do que é, de uma realidade objetiva. Essa distinção epistemológica é apresentada por Robert Stake (2011): “A distinção mais importante entre pesquisa qualitativa e pesquisa quantitativa não é baseada na distinção entre descrição verbal e dados numéricos. É, na verdade, uma diferença entre o estudo do conhecimento pessoal e o estudo de medidas objetivas" (STAKE, 2011, p. 67).

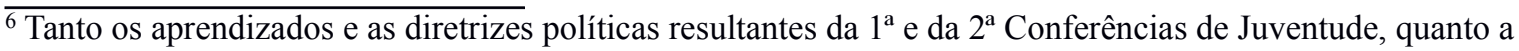
agenda política da Secretaria Nacional de Juventude (SNJ) e da Diretoria de Novas Mídias da Secretaria Geral da Presidência da República podem oferecer elementos contextuais importantes para explicar a decisão pela produção de uma tecnologia que inovasse no contexto das conferências nacionais e que fosse produzida em um processo de associação ou colaboração com a sociedade.
} 
A principal diferença, portanto, é de ênfase. Os métodos qualitativos são embasados na compreensão experiencial - utilizam o julgamento pessoal (dos investigadores) como base para afirmações. Para tais métodos, a identificação de padrões é importante para que seja possível empreender a análise e construir conclusões. A proximidade do investigador com o objeto (conhecimento prévio, envolvimento, etc) não é um problema em si, como Stake (2011) deixa claro: "Quando é possível, os pesquisadores experienciais trabalham pessoalmente com a atividade, os problemas, as expectativas as ambiguidades e as contradições, em alguns casos envolvendo-se completamente”. (STAKE, 2011, p. 73)

Em resumo, o estudo qualitativo com abordagem interpretativa, fixan-se nos significados das relações humanas a partir de diferentes pontos de vista, considerando os contextos únicos em que elas acontecem. Para esta ênfase, segundo Stake (2011, p. 30), "entender como as coisas funcionam depende, em grande parte, de observar de maneira ampla como algumas coisas específicas funcionam". O autor continua: "Talvez as diferenças metodológicas mais importantes entre qualitativo e quantitativo sejam duplas: a diferença entre (1) tentar explicar e (2) tentar compreender e a diferença entre (1) um papel pessoal e (2) um papel impessoal para o pesquisador" (ibidem).

A observação, a entrevista e a análise dos materiais (inclusive de documentos) são os métodos de pesquisa qualitativa mais comuns. O objetivo do pesquisador passa a ser a seleção de objetos que ofereçam a possibilidade de compreender melhor como certos fenômenos funcionam e possam revelar aspectos capazes inclusive de modificar as percepções atuais ou correntes sobre eles.

A escolha do conceito proposto por Anita Stefani (CGTPS) ofereceu uma referência conceitual e metodológica importante para esta pesquisa, antes mesmo do início da coleta de dados, apoiando a escolha dos entrevistados e os temas a serem investigados com eles, bem como a pesquisa e a seleção dos documentos. Este tipo de escolha é defendido por Javier Gil Flores (1994):

As categorias utilizadas em um estudo podem ser estabelecidas a priori, de acordo com o marco teórico e conceitual prévio, com as questões ou hipóteses que guiam a pesquisa, com as categorias já usadas em estudos de outros pesquisadores ou instrumentos de pesquisa empregados (o uso de questionários ou roteiros de entrevista, por exemplo, permite utilizar as questões levantadas como fonte de categorias úteis para organizar os dados). (GIL FLORES, 1994, p. 48, tradução nossa) 
Tal referência não impede, no entanto, que a coleta e a análise dos dados possam motivar modificações nos elementos deste conceito, muito pelo contrário. Como aponta Godoy (2006):

Hartley (1995) defende a ideia de que é importante contar com uma estrutura teórica de referência antes de iniciar o trabalho de campo. No entanto, este referencial deve ser amplo e não se constituir um elemento impeditivo para o aparecimento de novas ideias e conceitos explicativos. (GODOY, 2006, p. 132)

Neste caso, a pesquisa utilizou o constructo teórico de Capacidades de Governo Relacionadas à Utilização de TICs em Processos de Participação Social (CGTPS) construído por Stefani (2015) e por se tratar de um trabalho de pesquisa qualitativa, que utiliza o método de estudo de caso, a interpretação dos dados coletados marcou todo o processo de análise e decodificação. Nesse sentido, Fernandes afirma que "a análise qualitativa se caracteriza por buscar uma apreensão de significados na fala dos sujeitos, interligada ao contexto em que eles se inserem e delimitada pela abordagem conceitual (teoria) do pesquisador" (FERNANDES, 1991 apud ALVES e SILVA, 1992, p. 65).

Para Woods (1989 apud GIL FLORES, 1994, p. 33) a análise de dados seria um conjunto de manipulações e operações realizadas para extrair significado a partir dos dados e que seja relevante em relação ao problema de pesquisa. Spradley (1979, p. 92 apud GIL FLORES, 1994, p. 31) caracteriza qualquer análise como "um processo de pensamento. Refere-se ao exame sistemático de algo para determinar suas partes, as relações entre as partes e suas relações com o todo". Este processo de pensamento, ou de operações, teria o objetivo reduzir e extrair dados para verificar conclusões, como apresenta Gil Flores (1994): "Na descrição de tais tarefas, adotamos a distinção estabelecida por Miles e Huberman (1984), para quem, nas análises concorrem atividades orientadas a redução de dados, apresentação de dados e extração ou verificação de conclusões" (GIL FLORES, 1994, p. 45, tradução nossa).

Por fim, a análise e a codificação dos dados coletados através de documentos e entrevistas foi importante e será apresentada na seção 3.4 com maiores detalhes. Como ensina Stake (2011): “A codificação (classificar, organizar) é uma característica comum da micropesquisa e de todas as análises e sínteses qualitativas. Codificar é organizar todos os conjuntos de dados de acordo com tópicos, temas e problemas importantes para o estudo" (2011, p. 166).

Justamente a interconexão destes processos de coleta e análise nas pesquisas é destacada por Gil Flores (1994), para quem a progressiva construção teórica determina a coleta de dados, enquanto, por outro lado, a análise vai modificando e construindo tais 
conceitos. Tal ideia, reforçada por Wilson (1977), foi sintetizada por Javier Gil Flores da seguinte forma: "Coleta e análise se condicionam mutuamente, portanto, em um processo no qual a informação coletada e a teoria que emerge de sua análise são usadas para orientar uma nova coleta de dados" (FLORES, 1994, p. 35, tradução nossa).

No mesmo sentido, Tesch (1990, p. 91 apud GIL FLORES, 1994, p. 50) afirma que durante a codificação "o investigador descobre normalmente que as categorias desenvolvidas no início não são sempre adequadas. Podem necessitar ser renomeadas, modificadas em seu conteúdo ou substituídas por outras novas". A interconexão entre a coleta e a codificação também é ressaltada por Alves e Silva (1992):

O momento de sistematização é pois um movimento constante, em várias direções:
das questões para a realidade, desta para a abordagem conceituai, da literatura para
os dados, se repetindo e entrecruzando até que a análise atinja pontos de "desenho
significativo de um quadro", multifacetado sim, mas passível de visões
compreensíveis. (ALVES; SILVA, 1992, p. 65)

Em resumo, o referencial metodológico escolhido por esta pesquisa norteou as primeiras coletas e o início da análise, que por sua vez indicou novas orientações e rumos para a coleta e para o debate do próprio referencial teórico.

O que se espera nesta pesquisa é construir uma interpretação, à luz do referencial conceitual e metodológico escolhido, sobre o processo de desenvolvimento do software utilizado pela $3^{\text {a }}$ Conferência Nacional de Juventude, enfocando as capacidades estatais mobilizadas e, a partir do conceito de Stefani de Capacidade de Governo Relacionadas à Utilização de TICs em Processos de Participação Social.

A Para isso, a pesquisa investigou as opiniões e os pontos de vista dos principais atores envolvidos, tentando mapear todas as visões sobre e a multiplicidade de processos de

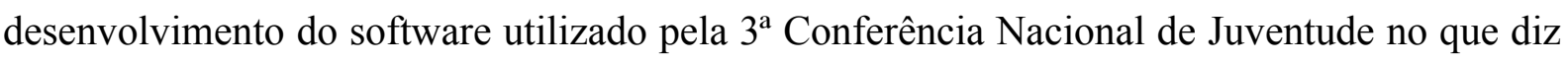
respeito às capacidades estatais mobilizadas. Para isso, lançou mão do método de entrevistas semi-estruturadas:

A entrevista semi-estruturada tem como objetivo principal compreender os significados que os entrevistados atribuem às questões e situações relativas ao tema de interesse. (...). São pertinentes quando o assunto a ser pesquisado é complexo, pouco explorado ou confidencial e "delicado". (GODOY, 2006, p. 134)

O roteiro das entrevistas (apresentado no Apêndice A desta dissertação) se baseou no roteiro estruturado por Stefani (2015), mantendo uma vinculação ao referencial conceitual e metodológico escolhido aqui, ainda que as primeiras entrevistas servissem como um esforço de aproximação, compreendendo alguns ajustes ou modificações que facilitassem a dinâmica 
da entrevista, o entendimento por parte dos entrevistados ou mesmo a ênfase nos elementos técnicos e tecnológicos pretendidos. Em outras palavras, o referencial serviu como "uma direção, ainda que não de forma totalmente declarada, para o conteúdo que vai ser obtido nas entrevistas" (QUEIROZ, 1987 apud ALVES; SILVA, 1992, p. 63).

A partir do referencial conceitual e metodológico escolhido, definiram-se quatro núcleos de interesse da pesquisa, abordando aspectos políticos, institucionais, administrativos e técnicos. Cada entrevistado(a) poderia fazer parte de mais de um desses núcleos, de acordo com o papel desempenhado no processo, mas a separação buscou facilitar as diferentes ênfases durante as entrevistas e também possibilitou refletir sobre determinadas situações em que uma ou outra pergunta do roteiro de entrevista poderia ser deixada de lado.

A seleção dos primeiros entrevistados teve como critério a sua participação direta na equipe de gestão geral da $3^{\mathrm{a}}$ Conferência Nacional de Juventude (incluindo o acompanhamento das atividades de desenvolvimento do software) ou na equipe de desenvolvedores responsáveis pelas tecnologias. A cada novo entrevistado(a) foi pedida uma lista com os nomes e funções dos principais envolvidos no processo confirmando quem deveria ser ouvido para a coleta de dados sobre as quatro dimensões de capacidades estatais (política, institucional, técnica e administrativa).

Quadro 8 - Lista de Entrevistados

(continua)

\begin{tabular}{|c|c|c|c|c|c|}
\hline $\begin{array}{l}\text { Núcleo(s) } \\
\text { do(s) qual(is) } \\
\text { participou }\end{array}$ & Nome & Cargo/ Órgão & Objetivos da entrevista & $\begin{array}{l}\text { Data da } \\
\text { entrevista } \\
(\mathrm{dd} / \mathrm{mm} / \mathrm{aa})\end{array}$ & $\begin{array}{l}\text { Duração da } \\
\text { entrevista } \\
\text { (hr:min:seg) }\end{array}$ \\
\hline \multirow[t]{2}{*}{$\begin{array}{l}\text { Todos (ainda } \\
\text { que de maneira } \\
\text { mais pontual) }\end{array}$} & $\begin{array}{l}\text { Ricardo } \\
\text { Poppi }\end{array}$ & $\begin{array}{l}\text { Coordenador de } \\
\text { novas mídias da } \\
\text { Secretaria-Geral } \\
\text { da Presidência } \\
\text { da República }\end{array}$ & $\begin{array}{l}\text { Investigação mais ampla sobre } \\
\text { questões administrativas, } \\
\text { institucionais e técnicas (escolha } \\
\text { dos instrumentos de gestão } \\
\text { utilizados) }\end{array}$ & $\begin{array}{l}14 / 10 / 06 \\
12 / 08 / 07\end{array}$ & $\begin{array}{l}01: 1554 \\
58: 32\end{array}$ \\
\hline & $\begin{array}{l}\text { Carla } \\
\text { Bezerra }\end{array}$ & $\begin{array}{l}\text { Coordenadora- } \\
\text { Geral da } 3^{\mathrm{a}} \\
\text { Conferência } \\
\text { Nacional de } \\
\text { Juventude }\end{array}$ & $\begin{array}{l}\text { Avaliar ponto de vista dos } \\
\text { principais gestores envolvidos no } \\
\text { processo e quais suas } \\
\text { interpretações a respeito das } \\
\text { especificidades da coprodução de } \\
\text { TICs e dos recursos existentes, } \\
\text { mobilizados ou inexistentes que } \\
\text { são importantes }\end{array}$ & $30 / 06 / 07$ & $01: 06: 23$ \\
\hline Técnico & $\begin{array}{l}\text { Caio } \\
\text { Sacramento }\end{array}$ & Consultor & $\begin{array}{l}\text { Avaliar ponto de vista de quem } \\
\text { atuou fora da gestão } \\
\text { Ênfase nos detalhes técnicos e na }\end{array}$ & $\begin{array}{l}30 / 09 / 06 \\
04 / 07 / 07\end{array}$ & $\begin{array}{l}51: 18 \\
30: 31\end{array}$ \\
\hline
\end{tabular}




\begin{tabular}{|c|c|c|c|c|c|}
\hline & & & $\begin{array}{l}\text { relação entre consultores da } \\
\text { sociedade e gestores } \\
\text { Atuação na comunidade do } \\
\text { software Noosfero }\end{array}$ & & \\
\hline & Hugo Melo & Consultor & $\begin{array}{l}\text { Principais dificuldades no trabalho } \\
\text { conjunto com Serpro e SNJ }\end{array}$ & $29 / 06 / 07$ & $30: 57$ \\
\hline & $\begin{array}{l}\text { Fabiano } \\
\text { Rangel }\end{array}$ & Consultor & $\begin{array}{l}\text { Detalhes das interações com } \\
\text { órgãos (supervisão, } \\
\text { acompanhamento, colaboração etc) }\end{array}$ & $04 / 07 / 07$ & $40: 01$ \\
\hline & $\begin{array}{l}\text { Marcos } \\
\text { Ronaldo }\end{array}$ & Consultor & Detalhes sobre contratação & $29 / 06 / 07$ & $36: 40$ \\
\hline $\begin{array}{l}\text { Técnico e } \\
\text { Administrativo }\end{array}$ & $\begin{array}{l}\text { Leandro } \\
\text { Nunes }\end{array}$ & Serpro & $\begin{array}{l}\text { Detalhes sobre e gestão do } \\
\text { processo produtivo sob a } \\
\text { perspectiva da supervisão técnica } \\
\text { (DITEC) e da empresa contratada } \\
\text { (Serpro) }\end{array}$ & $14 / 08 / 07$ & $31: 52$ \\
\hline $\begin{array}{l}\text { Político e } \\
\text { Institucional }\end{array}$ & $\begin{array}{l}\text { Tamara } \\
\text { Terso }\end{array}$ & $\begin{array}{l}\text { Secretária } \\
\text { Executiva do } \\
\text { Conselho } \\
\text { Nacional de } \\
\text { Juventude }\end{array}$ & $\begin{array}{l}\text { Ênfase nas questões contextuais } \\
\text { (políticas e institucionais) que } \\
\text { permearam o processo }\end{array}$ & $15 / 08 / 07$ & $34: 25$ \\
\hline $\begin{array}{l}\text { Político e } \\
\text { Institucional } \\
\text { (mas teve } \\
\text { contato com } \\
\text { todas as } \\
\text { dimensões) }\end{array}$ & $\begin{array}{l}\text { Gabriel } \\
\text { Medina }\end{array}$ & $\begin{array}{l}\text { Secretário } \\
\text { Nacional de } \\
\text { Juventude }\end{array}$ & $\begin{array}{l}\text { Objetivos políticos da Conferência } \\
\text { e opção por desenvolver um app } \\
\text { específico }\end{array}$ & $15 / 08 / 07$ & 49:07 \\
\hline
\end{tabular}

Fonte: Henrique Carlos Parra Parra Filho, 2018.

Cuidando para cobrir todas as dimensões teóricas de capacidades estatais importantes para a investigação, as entrevistas buscaram possibilitar aos entrevistados darem longas respostas e estimulou que apresentassem suas próprias opiniões e interpretações, ainda que tivessem parte das informações ou mesmo acompanhassem determinados fatos e decisões à distância durante o processo. Além das entrevistas com os principais atores envolvidos, a pesquisa coletou dados de alguns documentos produzidos pela $3^{\text {a }}$ Conferência Nacional de Juventude e que se encontravam organizados no sítio oficial do Portal da Juventude, na seção “Conferência” (SNJ)7. Neste espaço foi possível observar notícias com a cobertura jornalística de todo o processo $^{8}$, o regimento na íntegra ${ }^{9}$, as resoluções aprovadas pela Comissão Organizadora Nacional ${ }^{10}$, bem como a descrição das etapas ${ }^{11}$, especialmente da etapa virtual.

\footnotetext{
${ }^{7}$ Disponível em: $<\underline{\text { http://juventude.gov }}$.br/profile/conferencia $>$. Acesso em: 11/02/18.

${ }^{8}$ Disponível em: $<\underline{\text { http: } / / j u v e n t u d e . g o v . b r / c o n f e r e n c i a / n o t i c i a s ~}>$. Acesso em: 11/02/18.

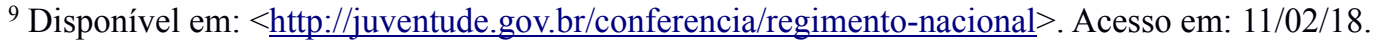

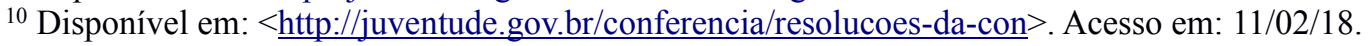

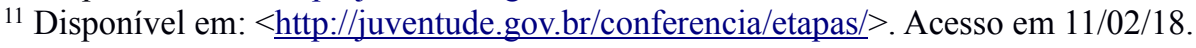


De maneira geral, a coleta e análise de documentos foi importante para ampliar as percepções a respeito do caso estudado, corroborando e ampliando as evidências oriundas das entrevistas.

Durante as entrevistas e a partir da revisão de literatura foi identificada a necessidade de uma investigação mais detalhada sobre a contratação e o desenvolvimento de tecnologia por parte da Administração Pública Federal. Por isso, realizou-se a análise da Instrução Normativa N 4 de 11 de Setembro de 2014 (STI, 2014); do Guia de Boas Práticas em Contratação de Soluções de Tecnologia da Informação (STI, 2017a); do documento de "Boas práticas, vedações e orientações para contratação de software e de serviços de desenvolvimento e manutenção de sistemas (Fábrica de Software)" (STI, 2017b); e do Relatório da Auditoria Operacional realizada mediante autorização do Tribunal exarada no Acórdão no 505/2015 (TCU, 2015).

A análise documental teve papel importante de ampliar a coleta de informações e esclarecer algumas informações relevantes para as entrevistas e especialmente para a análise de seus dados, que foi realizada a partir da metodologia de Gil Flores (1994), que propõe processos analíticos para seleção, abstração e simplificação dos dados coletados:

De forma resumida, Flores define a análise de dados como: - o conjunto de
manipulações, transformações, operações, reflexões e comprovações realizadas a
partir dos dados com o fim de extrair significado relevante em relação a um
problema de pesquisa.l (1994, p. 33). Em geral, o processo de análise de dados
envolve alguns princípios e tarefas básicas como: redução de dados (separação de
elementos, identificação e classificação desses elementos e agrupamento);
disposição de dados; e obtenção e verificação de conclusões.(STEFANI, 2015, p.
93).

Todas as entrevistas foram transcritas, totalizando cerca de 9 horas e 119 páginas de material coletado. Os entrevistados assinaram termo concordando com que as informações e opiniões coletadas nas entrevistas compreenderiam as análises e estariam sujeitas a interpretação na presente dissertação. Contudo, não há autorização para a publicação dos áudios e das consequentes transcrições, por questões corporativas, éticas e políticas. Desta feita, esta investigação decidiu por referenciar as entrevistas e os entrevistados, mas não citálos diretamente. É de nossa responsabilidade, portanto, a referência a essas entrevistas e o uso delas para as análises nesta dissertação. A guarda dessas entrevistas está com o pesquisador, que pode analisar eventual pedido de uso delas por terceiros, desde que estes mantenham o compromisso de não publicar transcrição, não identificar os autores e não utilizar citações diretas. 
A análise deste material buscou inicialmente categorizar os entrevistados de modo que cada um correspondesse a uma letra (A, B, C, etc). Suas entrevistas foram então analisadas e o material dividido em Unidades de Análise, numeradas de maneira sequencial dentro do universo de todas as entrevistas. Cada Unidade de Análise precisa corresponder a uma ideia ou um argumento, ou seja, uma resposta pode conter mais de uma Unidade de Análise, por exemplo.

Se o material coletado com entrevistado A revelasse quatro Unidades de Análise, por exemplo, a primeira Unidade de Análise identificada no material coletado com o entrevistado B seria a de número cinco (5). Em outras palavras, todo o material foi sistematizado em uma quadro como esta:

Quadro 9 - Sistematização das unidades de análise

\begin{tabular}{|l|l|}
\hline Entrevistado & Unidade de Análise \\
\hline A & 1 \\
\hline A & 2 \\
\hline A & 3 \\
\hline A & 4 \\
\hline B & 5 \\
\hline
\end{tabular}

Fonte: Henrique Carlos Parra Parra Filho, 2018.

Além disso, cada Unidade de Análise foi sistematizada com a respectiva letra (código que identifica o entrevistado) e também com o código da categoria ou subcategoria de capacidade estatal segundo o conceito de Capacidade de Governo para Utilização de TICs em Processos de Participação Social (STEFANI, 2015).

Quadro 10 - Relação geral de capacidades de governo relacionadas à utilização de TICs em processo de participação social (CGTPS)

\begin{tabular}{|l|l|l|}
\hline Categoria & Subcategorias & Código \\
\hline \multirow{3}{*}{ Capacidade Institucional - CGITPS } & Institucionalidade do Processo & INST \\
\cline { 2 - 3 } & Pluralidade Institucional do Governo & PLUR \\
\hline \multirow{5}{*}{ Capacidade Técnica - CGTTPS } & Recursos Humanos & RH \\
\cline { 2 - 3 } & Recursos Financeiros e Físicos & FIN \\
\cline { 2 - 3 } & Tecnologia & TECN \\
\cline { 2 - 3 } & Gestão do Processo Participativo & GES \\
\hline Capacidade Administrativa - CGATPS & TI na Administração Pública & TI \\
\hline
\end{tabular}




\begin{tabular}{|l|l|l|}
\hline & Locus do Tema no Governo & LOC \\
\hline \multirow{4}{*}{ Capacidade Política - CGPTPS } & Participação como Método de Governo & MET \\
\cline { 2 - 3 } & Liderança e Condução Política & LID \\
\cline { 2 - 3 } & Comunicação & COM \\
\hline
\end{tabular}

Fonte: Anita Stefani, 2015.

Dessa forma, ao relacionar Entrevistado, Unidade de Análise, Categoria e Subcategoria, a sistematização de todo o conteúdo foi realizada segundo o exemplo:

Quadro 11 - Classificação das unidades de análise

\begin{tabular}{|l|l|l|l|}
\hline Entrevistado & Unidade de Análise & Categoria & Subcategoria \\
\hline A & 1 & CGTTPS & TECN \\
\hline A & 2 & & \\
\hline A & 3 & & \\
\hline A & 4 & & \\
\hline B & 5 & & \\
\hline
\end{tabular}

Fonte: Henrique Carlos Parra Parra Filho, 2018.

A sistematização desta maneira auxiliou a identificar recorrência de categorias e subcategorias por unidade de análise, distinguindo aquelas que eventualmente pudessem ser mais importantes para o estudo do caso em questão. Também facilitou a visualização sobre Unidades de Análise que pareciam se referir a mais de uma subcategoria (de maneira esporádica ou recorrente), ou ainda a nenhuma das subcategorias em questão.

A partir desta técnica de agregação, foi possível analisar com mais atenção todas as unidades classificadas dentro da subcategoria de tecnologia, de maneira exclusiva ou não (muitas unidades foram classificadas em mais de uma categoria). Ela ainda possibilitou analisar os casos que ficaram sem classificação. Este universo de unidades ocupou o centro da atenção do esforço de análise. Vale assinalar que essa técnica, apesar de ter características quantitativas, não caracteriza uma abordagem quantitativa ou altera a escolha pelo método qualitativo. A análise da recorrência de termos para determinar e caracterizar categorias e subcategorias, utilizada por Stefani (2015), não altera a abordagem qualitativa de seu trabalho, assim como não altera nesta pesquisa. Esse tipo de operação, para Miles e Huberman (1984), faz parte dos métodos qualitativos já que "quando identificamos um tema ou modelo estamos isolando algo que ocorre um número de vezes e que ocorre consistentemente de um modo específico" (MILES; HUBERMAN, 1984, p. 215 apud GIL FLORES, 1994, p. 42). 
Os resultados desta agregação e da classificação empreendidas pela pesquisa serão apresentados de maneira resumida a seguir e com maiores detalhes nos Capítulos 4 e 5, quando serão discutidas.

\subsection{AnÁlise dos DAdos}

As 11 entrevistas realizadas com 9 entrevistados totalizaram 503 minutos e 40 segundos de áudio e foram transcritas, resultando 119 páginas de material. Dos 11 entrevistados, 6 têm conhecimentos técnicos e atuaram diretamente no processo de desenvolvimento das tecnologias utilizadas pela $3^{\text {a }}$ Conferência Nacional de Juventude. Também foram analisadas 58 páginas dos documentos oficiais da $3^{\text {a }}$ Conferência Nacional de Juventude (Resoluções que tratavam da etapa digital e Regimento).

A análise das entrevistas sistematizou 219 unidades de análise, classificadas de acordo com as 11 subcategorias que compõem o conceito de Capacidades de Governo Relacionadas à Utilização de TICs em Processos de Participação Social (CGTPS) apresentado por Anita Stefani (2015). Dentre essas mais de duas centenas de unidades de análise, 82 foram categorizadas dentro da subcategoria Tecnologia; TI na Administração Pública teve 43; 28 unidades de análise na subcategoria de Recursos Humanos; 19 na de Recursos Financeiros e Físicos; a subcategoria de Gestão do Processo Participativo veio logo a seguir, com 10 unidades de análise; Liderança e Condução Política teve 9 unidades; seguida de Institucionalidade do Processo e Pluralidade Institucional do Governo, com 8 cada uma. Participação como Método de Governo (5 unidades de análise), Lócus do Tema no Governo (4 unidades de análise) e Comunicação (3 unidades de análise) completam a sistematização.

Quadro 12 - Síntese das Unidades de Análise observadas

\begin{tabular}{|l|c|}
\hline Subcategoria & Quantidade de Unidades de Análise observadas \\
\hline Tecnologia & 82 \\
\hline TI na Administração Pública & 43 \\
\hline Recursos Humanos & 28 \\
\hline Recursos Financeiros e Físicos & 19 \\
\hline Gestão do Processo Participativo & 10 \\
\hline Liderança e Condução Política & 9 \\
\hline Institucionalidade do Processo & 8 \\
\hline Pluralidade Institucional do Governo & 8 \\
\hline
\end{tabular}




\begin{tabular}{|l|c|}
\hline Participação como Método de Governo & 5 \\
\hline Lócus do Tema no Governo & 4 \\
\hline Comunicação & 3 \\
\hline
\end{tabular}

Fonte: Henrique Carlos Parra Parra Filho, 2018.

A quantidade de unidades de análise acaba representando não apenas a ênfase dada pelas entrevistas, mas sobretudo o fato de que mais da metade dos entrevistados atuaram no desenvolvimento das tecnologias utilizadas pela Conferência. No entanto, as entrevistas com quatro atores mais centrais que acompanharam as dimensões administrativas e políticas garantiram também a análise para além do processo técnico de desenvolvimento. 


\section{ApresentaÇão do Caso}

A $3^{\text {a }}$ Conferência Nacional de Juventude foi realizada sob responsabilidade da Secretaria Geral da Presidência da República, por meio da Secretaria Nacional de Juventude e do Conselho Nacional de Juventude, como estabelece o artigo $1^{\circ}$ de seu Regimento ${ }^{12}$. A conferência foi realizada entre maio e dezembro de 2015, período no qual ocorreram as etapas Livres e Territoriais, etapas das Juventudes de Povos e Comunidades Tradicionais, Municipais, Regionais, Estaduais, do Distrito Federal e Nacional.

As etapas livres eram encontros organizados por quaisquer pessoas ou organizações com o objetivo de discutir os temas da Conferência e elaborar propostas para a etapa digital, onde essas propostas poderiam ser incluídas. Já a etapa digital foi realizada inteiramente no ambiente digital da $3^{\text {a }}$ Conferência e não demandava participação em eventos presenciais. Nela, qualquer pessoa poderia apresentar propostas e discutir sobre o que estava proposto no ambiente digital, elegendo propostas e delegados diretamente para a etapa nacional. Ou seja, o uso de etapas livres fortaleceria a etapa digital e daria a possibilidade de as etapas livres poderem eleger propostas e delegados, mas não se constituía como exigência para quem decidisse participar da etapa digital.

As etapas municipais, regionais ou territoriais foram encontros realizados por um ou mais municípios para discutir as propostas daquela cidade ou região e eleger os delegados à etapa estadual correspondente. A etapa regional precisava ser composta por dois ou mais municípios contíguos que decidissem realizar conjuntamente a sua etapa. Já as etapas territoriais eram aquelas realizadas pelos Territórios da Cidadania e de Identidade, definidos pelo Governo Federal.

Etapas estaduais e do Distrito Federal foram os encontros realizados para debater as propostas originadas nas etapas municipais e regionais, além de elaborar propostas e eleger delegados e delegadas à etapa nacional. Em geral, seus participantes são os delegados e delegadas eleitos nas etapas municipais e regionais, com a participação também de gestores dos governos estaduais e conselheiros estaduais. Esse fluxo entre etapas municipais, estaduais e nacional é uma das características mais importantes das Conferências Nacionais.

Além do uso em uma etapa específica (etapa digital), já nos seus primeiros artigos, o Regimento da $3^{\text {a }}$ Conferência Nacional de Juventude (SECRETARIA GERAL, 2015, s.p.) estabelece que “(...) utilizará os recursos da plataforma digital em todas as suas etapas”, 
deixando clara a ênfase que o uso de TICs teria no processo. Tal importância também fica evidente no Artigo $6^{\circ}$, que apresenta os objetivos da conferência:

Art. $6^{\circ}$. A $3^{\circ}$ Conferência Nacional de Juventude tem por objetivo geral atualizar a
agenda da juventude para o desenvolvimento do Brasil, reconhecendo e
potencializando as múltiplas formas de expressão juvenil, além de fortalecer o
combate a todas as formas de preconceitos e os seguintes objetivos específicos: [...]
XI - reconhecer e fortalecer o ambiente digital como espaço de participação,
articulação, deliberação e ação dos jovens; XII - consolidar uma plataforma de
participação digital; XIII - fortalecer, ampliar e diversificar o acesso da sociedade
civil, em especial da juventude, aos mecanismos de participação popular e políticas
públicas de juventude (SECRETARIA GERAL, 2015, s.p.)

O uso de tecnologias no processo é visto pelos atores entrevistados como estratégico para ampliar e diversificar a participação dos jovens, ou seja, para mobilizar e interagir com jovens que não têm histórico e perfil de engajamento político - geralmente em partidos e movimentos sociais - e que já tenham participado da primeira ou da segunda conferência nacional. De fato, esse desejo de ampliação e diversificação aparece no regimento, em diversas notícias e mesmo em algumas entrevistas. O tema também é destacado em parte da literatura de Conferências Nacionais, como um dos desafios de inclusão política (TEIXEIRA; SOUZA; LIMA, 2012).

Como foi apresentado no Capítulo 2, a própria literatura sobre Conferências Nacionais destaca o desafio de ampliar a participação social para além de um público mais engajado e geralmente associado a ONGs, movimentos sociais, entidades ou partidos, e os potenciais do uso de TICS para responder a esse desafio chegam a ser debatidos (TEIXEIRA; SOUZA; LIMA, 2012, p. 27). A Secretaria Nacional de Juventude (SNJ) buscou responder a esse desafio, o que ajuda a explicar o fato de esta ter sido a primeira conferência que utilizou tecnologias e uma etapa virtual tanto para eleger propostas para a etapa nacional, quanto para eleger delegados (participantes) que participariam desta etapa:

Art. 15. Por meio da Plataforma Digital será possível eleger delegados e propostas para a etapa nacional da $3^{\circ}$ Conferencia Nacional de Juventude conforme critérios estabelecidos por este regimento.

Parágrafo Único - A Comissão Organizadora Nacional expedirá resoluções sobre o uso da plataforma digital na $3^{\circ}$ Conferência Nacional de Juventude. (SECRETARIA GERAL, 2015, s.p.)

Trata-se da primeira experiência (e única até o presente momento) de uso de TICs em uma Conferência Nacional de maneira plena, ou seja, para as funções ou dimensões participativa, representativa e deliberativa que caracterizam uma conferência, conforme apresentado no Capítulo 2 (FARIA et al, 2012). Em outras palavras, este é o único caso em 
que uma tecnologia digital foi utilizada em uma Conferência Nacional para eleger propostas e para eleger delegados, de maneira integrada ao processo tradicional.

O quadro a seguir caracteriza, à luz das três dimensões citadas do uso de TICs (ou seja, participativa, representativa e deliberativa), as quatro Conferências Nacionais que utilizaram TICs como ferramenta de participação política:

Quadro 13 - Dimensões do uso de TICs em conferências

\begin{tabular}{|l|c|l|l}
\hline Conferência & Participativa & $\begin{array}{l}\text { Representativa } \\
\text { (eleger delegados) }\end{array}$ & $\begin{array}{l}\text { Deliberativa } \\
\text { (eleger propostas) }\end{array}$ \\
\hline $\begin{array}{l}1^{\text {a }} \text { Conferência sobre Transparência e } \\
\text { Controle Social (2012) }\end{array}$ & $\mathrm{X}$ & $\mathrm{X}$ & \\
\hline $3^{\mathrm{a}}$ Conferência de Cultura $(2013)^{14}$ & $\mathrm{X}$ & & \\
\hline Conferência de Educação $2014^{15}$ & $\mathrm{X}$ & & $\mathrm{X}$ \\
\hline $3^{\text {a }}$ Conferência de Juventude $(2015)^{16}$ & $\mathrm{X}$ & $\mathrm{X}$ & \\
\hline
\end{tabular}

A metodologia da $3^{\text {a }}$ Conferência de Juventude buscou a capacidade de divulgação e comunicação, premiando com pontos os participantes que conseguissem atrair apoios e comentários em suas propostas. Além disso, buscou estimular uma postura mais colaborativa por parte dos participantes, pontuando ainda os comentários e apoios feitos a outras propostas. Esta lógica de pontos e incentivos foi proposta pela SNJ, deliberada e aprovada pela Comissão Nacional Organizadora (CON); e orientou as funcionalidades e o desenvolvimento da tecnologia, se tornando a métrica para a seleção das propostas e delegados:

Art. 42. Serão considerados delegados e delegadas, eleitos/as pela plataforma digital, os usuários com maior capacidade de interação e proposição realizada na plataforma, a partir dos seguintes critérios:

I - valorização do uso das redes de forma colaborativa, no qual o usuário tenha capacidade de contribuir com propostas já feitas referentes aos 11 eixos temáticos, valorizando as experiências do seu território nas políticas públicas de juventude; comparando as demandas sociais juvenis com as políticas existentes e sabendo identificar os limites e avanços destas políticas para a transformação da realidade local dos jovens; II - valorização da mobilização nas redes, explorando a capacidade do usuário em adquirir adesão às suas propostas em torno dos 11 eixos temáticos; levando em consideração o engajamento político destes usuários e o discurso agregador em torno de propostas que ampliam os direitos da juventude brasileira; III - valorização da formulação de propostas em torno dos 11 eixos temáticos, no qual o

${ }^{13}$ Disponível em: <http://www.cgu.gov.br/assuntos/controle-

social/consocial/arquivos/consocial_resumo_conferencia_virtual.pdf $>$. Acesso em: 14/02/18.

${ }^{14}$ Disponível em: $<$ http://www.cultura.gov.br/banner-1/-/asset_publisher/G5fagiDe7rqz/content/conferenciavirtual-da-iii-cnc/10883>. Acesso em: 14/02/18.

${ }_{15}$ Disponível em: $<$ https://undime.org.br/noticia/rede-social-conae2014-facilita-organizacao-de-conferenciaslivres. $>$. Acesso em: 14/02/18.

${ }_{16}$ Disponível em: < http://juventude.gov.br/juventude/noticias/vemmudarobrasil-snj-lanca-aplicativo-da-3aconferencia-nacional-de-juventude\#.WIdXe7YrKRs $>$. Acesso em: 14/02/18. 
usuário tenha capacidade de refletir os desafios colocados no país para construção de uma sociedade inclusiva e promotora de direitos para a juventude, transversalizando a diversidade juvenil nas políticas públicas; IV - participação em etapas livres covalidadas. (SECRETARIA GERAL, 2015, s.p.)

Em termos práticos, a relevância das propostas era definida por 4 (quatro) atividades: seguir, apoiar, comentar e mobilizar. Cada seguidor equivalia a 20 pontos; cada apoiador, 30 pontos; cada comentário, 50 pontos; e cada mobilizador, 70. O número total de cada atividade era então multiplicado por seu respectivo peso e a soma dos valores de cada atividade resultou no valor de relevância total da proposta. As 305 mais relevantes foram incluídas para deliberação e votação dos/as delegados/as da Etapa Nacional, equivalendo a 32,2\% das propostas enviadas à Etapa Nacional.

A regra de seleção dos/as delegados/as, aprovada e publicada em Resolução da Comissão Nacional Organizadora (CON), seguia uma lógica semelhante, de acordo com os mesmos objetivos:

Quadro 14 - Regra de pontuação da etapa digital

\begin{tabular}{|l|l|}
\hline I - Atividade realizada pelo/a participante & Pontos por atividade realizada \\
\hline a. Criar perfil básico & 100 (apenas uma vez por participante) \\
\hline b. Completar perfil & 100 (apenas uma vez por participante) \\
\hline c. Criar Proposta & 10 \\
\hline d. Seguir Proposta & 10 \\
\hline e. Apoiar proposta & 20 \\
\hline f. Comentar Proposta & 40 \\
\hline g. Mobilizar proposta & 60 \\
\hline h. Responder pesquisa & 200 (apenas uma vez por participante) \\
\hline $\begin{array}{l}\text { i. Ser membro de conselho municipal ou estadual } \\
\text { da juventude }\end{array}$ & 200 (apenas uma vez por participante) \\
\hline $\begin{array}{l}\text { II- Atividade recebida em cima da proposta de } \\
\text { um/a participante }\end{array}$ & Pontos por atividade realizada \\
\hline a. Ter sua Proposta seguida por outro participante & 20 \\
\hline b. Ter sua Proposta apoiada por outro participante & 30 \\
\hline $\begin{array}{l}\text { c. Ter sua Proposta comentada por outro } \\
\text { participante }\end{array}$ & 50 \\
\hline $\begin{array}{l}\text { d. Ter participantes inscrevendo-se para mobilizar } \\
\text { em prol da sua proposta }\end{array}$ & 70 \\
\hline
\end{tabular}

Ao final da etapa virtual da Conferência, o número total de cada atividade realizada pelos participantes foi multiplicado por sua respectiva pontuação. Assim, a soma dos valores de cada atividade resultava no valor da relevância do participante. A resolução estabeleceu ainda a possibilidade de eleger "As/Os 600 (seiscentos) participantes com maior valor de

${ }^{17}$ Disponível em: $<$ http://juventude.gov.br/articles/participatorio/0010/2309/Resolucao-01-2015-etapadigital.pdf $>$. Acesso em: 14/02/18. 
relevância no aplicativo" (SNJ, RESOLUÇÃO 001/2015 CON), desde que fossem observados critérios de I - paridade de gênero e proporcionalidade étnico-racial, conforme regimento e resoluções específicas; e II - diversidade regional.

Concretamente, o resultado final contemplou 484 participantes eleitos/as como delegados/as, cerca de trinta por cento do total de delegados/as da Etapa Nacional ${ }^{18}$ e 305 $\operatorname{propostas}^{19}$. No total foram 2.708 propostas criadas no aplicativo e 32.706 comentários feitos pelos 21.469 usuários, sendo que houve 7.940 novos usuários, desde junho de 2015, quando o aplicativo foi lançado dentro do já existente Portal da Juventude (que já tinha usuários ativos).

Os resultados de inclusão e participação podem ser observados quando se analisa a delegação eleita na etapa virtual:

Quadro 15 - Perfil dos delegados da etapa digital

\begin{tabular}{|c|c|c|}
\hline Gênero & Quantidade de delegados & $\%$ \\
\hline Feminino & 242 & 50 \\
\hline Masculino & 242 & 50 \\
\hline Total & 484 & 100 \\
\hline Etnia/Raça & Quantidade de delegados & $\%$ \\
\hline Branco & 148 & 30,57 \\
\hline Indígena & 6 & 1,23 \\
\hline Negro (pretos+pardos) & 330 & 68,18 \\
\hline Total & 484 & 100 \\
\hline Faixa Etária & Quantidade de delegados & $\%$ \\
\hline Menos de 15 anos & 2 & 0,41 \\
\hline Entre $15-29$ anos & 404 & 83,47 \\
\hline Mais de 30 anos & 56 & 11,57 \\
\hline Com erro no ano informado & 22 & 4,54 \\
\hline Total & 484 & 100 \\
\hline Região & Quantidade de delegados & $\%$ \\
\hline Centro-Oeste & 32 & 6,61 \\
\hline Nordeste & 221 & 45,66 \\
\hline Norte & 42 & 8,67 \\
\hline Sudeste & 141 & 29,13 \\
\hline
\end{tabular}

\footnotetext{
${ }_{18}$ Resultado disponível em: $<$ http://juventude.gov.br/articles/participatorio/0016/4432/resultado-delegadosas3.pdf > . Acesso em: 14/02/18.

${ }^{19}$ Segundo informações disponíveis em: $<$ http://juventude.gov.br/articles/participatorio/0016/3211/resultadopropostas.pdf $>$. Acesso em: 14/02/18.
} 


\begin{tabular}{|l|l|l|}
\hline Sul & 48 & 9,91 \\
\hline Total & 484 & 100 \\
\hline \multicolumn{2}{|l|}{ Fonte: Henrique Carlos Parra Parra Filho, 2018, a partir dos dados da SNJ, 11 de Novembro de 201520 }
\end{tabular}

Fonte: Henrique Carlos Parra Parra Filho, 2018, a partir dos dados da SNJ, 11 de Novembro de $2015^{20}$

Esses números revelam a expressiva participação de pessoas da Região Nordeste e de negros/as; e alguns dos depoimentos coletados na entrevista reforçam até mesmo a surpresa com estes resultados. Inicialmente inclusive se buscaram cotas mínimas de participação por região, etnia e gênero a partir do receio de que o uso de internet e de tecnologias se concentrasse excessivamente nas regiões mais desenvolvidas do Sudeste, majoritariamente entre brancos e homens. Essa preocupação foi relatada pela entrevistada Tamara Terso (2017), por exemplo, e está evidenciada no artigo 10 da Resolução 001/2015 da Comissão Organizadora Nacional ${ }^{21}$.

Para além da inclusão em termos de gênero, etnia e regiões, a Secretaria Nacional de Juventude (SNJ) também coletou, selecionou e divulgou alguns depoimentos de delegados digitais em seu sítio eletrônico, que ajudam a exemplificar quais foram, para eles, alguns dos efeitos e resultados da etapa virtual. Um deles foi Nelio Miguel Jr. (22 anos, Sergipe): “O aplicativo foi uma grande conquista que igualou todos os jovens e permitiu a participação até mesmo daqueles que moram em cidades onde não teve a conferência" (SNJ, 4 de dezembro de 2015, s.p.).

Em direção semelhante vai o depoimento de Moabe Fontes (17 anos, Sergipe), que destaca a possibilidade que a etapa virtual criou de incluir quem não se torna delegado pelas demais etapas: “Adorei a ideia porque dá uma voz incrível pra quem não tem como se destacar nas outras esferas. Foi maravilhoso!" (SNJ, 4 de dezembro de 2015, s.p.).

\footnotetext{
${ }^{20}$ Disponível em: $<\underline{\text { http://juventude.gov.br/conferencia/noticias/confira-a-lista-final-de-delegados-delegadas-e- }}$ propostas-eleitas-pelo-app-3confjuv: $>$. Acesso em: 14/02/18.

21 "Art. 10 - As/Os 600 (seiscentos) participantes com maior valor de relevância no aplicativo serão eleitos/as delegados/as à etapa nacional, observados também os critérios estabelecidos no artigo 43 do Regimento da $3^{\text {a }} \mathrm{CNJ}$, conforme abaixo:

I - paridade de gênero e proporcionalidade étnico-racial, conforme regimento e resoluções específicas;

II - no mínimo 50\% da delegação com idade entre 15 e 29 anos;

III - Diversidade regional, conforme a seguinte distribuição:

a. Região Norte: $10 \%$ da delegação, equivalente a 60 delegados/as;

b. Região Nordeste: $28 \%$ da delegação, equivalente a 168 delegados/as;

c. Região Centro-Oeste: $10 \%$ da delegação, equivalente a 60 delegados/as;

d. Região Sudeste: $37 \%$ da delegação, equivalente a 222 delegados/as;

e. Região Sul: $14 \%$ da delegação, equivalente a 84 delegados/as."
}

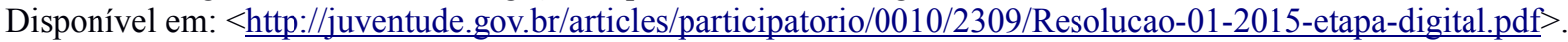
Acesso em 13/02/18. 
Lindemberg Theodoro (27 anos, Minas Gerais), outro participante eleito delegado pelo aplicativo, destaca o fato de que os participantes engajados pelo aplicativo não precisavam pertencer a grupos políticos, critério que acaba se mostrando muitas vezes determinante para a eleição de delegados entre as etapas municipais, estaduais e nacional: "O mais interessante da eleição foi a oportunidade de pessoas que como eu não fazem parte de nenhum movimento político, terem a oportunidade de construir um novo Brasil para todos nós" (SNJ, 4 de dezembro de 2015, s.p.)

Além do uso da tecnologia com o objetivo de eleição de propostas e de delegados, o caso também apresenta questões relevantes pelo método e processo empregados para produção da tecnologia, que envolveu a participação de consultores externos ao quadro da Administração Pública Federal, mobilizados especialmente para o desenvolvimento das tecnologias a serem empregados pela Conferência. Além disso, não houve apenas adoção ou uso de algum software ou tecnologia previamente existente, mas o efetivo desenvolvimento de funcionalidades e aplicações específicas para o caso.

Em resumo, houve a contratação de consultores da sociedade, o envolvimento da empresa pública de tecnologia $\left(\right.$ Serpro $^{22}$ ) e a adoção de um software livre (Noosfero) já utilizado pelo governo (Participa.br), mas que inicialmente foi desenvolvido pela sociedade (Colivre ${ }^{23}$ ) e em cuja comunidade de desenvolvimento há organizações sociais, empresas, governo e cidadãos não associados a organizações.

O quadro a seguir apresenta quatro elementos observados pela presente investigação. Dois deles dizem respeito aos usos que a tecnologia teve no processo conferencial (para eleição de propostas e para a eleição de delegados); um terceiro aspecto detalha qual foi a tecnologia utilizada apontando se foi desenvolvida solução nova ou se houve a adoção de alguma tecnologia existente; e, por fim, em quais conferências o instrumento de contratação de consultores externos foi utilizado na formação da equipe de desenvolvimento:

Quadro 16 - Aspectos de coprodução de TICs em conferências nacionais

Conferência Adotou ou produziu software/ app?

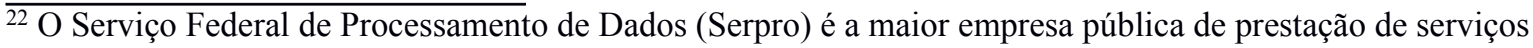
em tecnologia da informação do Brasil.

${ }^{23}$ A Colivre-Cooperativa de Trabalho em Tecnologias Livres é uma empresa cooperativa de serviços, formada no início de 2006, na cidade do Salvador, na Bahia, com o objetivo de contribuir para a difusão e o desenvolvimento de tecnologias livres. É criadora do projeto Noosfero, plataforma web para redes sociais lançada em 2009, participou da concepção do Cirandas.net (Disponível em: $<$ http://cirandas.net/>. Acesso em: 14/02/18.) e da reformulação do SotwareLivre.org (Disponível em: <http://softwarelivre.org/> . Acesso em: 14/02/18). 


\begin{tabular}{|c|c|c|c|c|}
\hline & & $\begin{array}{l}\text { deliberar } \\
\text { propostas (votar e } \\
\text { aprovar)? }\end{array}$ & (delegados)? & $\begin{array}{l}\text { sociedade no } \\
\text { desenvolvimento }\end{array}$ \\
\hline $\begin{array}{l}1^{a} \text {. Conferência sobre } \\
\text { Transparência e } \\
\text { Controle Social } \\
(2012)^{24}\end{array}$ & $\begin{array}{l}\text { Adotou o E-democracia } \\
\text { (software da Câmara } \\
\text { dos Deputados) }\end{array}$ & Sim & Não & Sim \\
\hline $\begin{array}{l}3^{\text {a }} \text { Conferência de } \\
\text { Cultura }(2013)^{25}\end{array}$ & $\begin{array}{l}\text { Adotou o Consulta } \\
\text { Pública e produziu } \\
\text { ambiente específico }\end{array}$ & Não ${ }^{26}$ & Não & $\begin{array}{l}\text { Sem informações a } \\
\text { respeito }\end{array}$ \\
\hline $\begin{array}{l}\text { Conferência de } \\
\text { Educação } 2014^{27}\end{array}$ & $\begin{array}{l}\text { Adotou o Joomla/ } \\
\text { plugin joomsocial }\end{array}$ & Não ${ }^{28}$ & Não & Sim \\
\hline $\begin{array}{l}3^{\text {a }} \text { Conferência de } \\
\text { Juventude }(2015)^{29}\end{array}$ & $\begin{array}{l}\text { Adotou o Participa. } B r \text { e } \\
\text { produziu app próprio }\end{array}$ & Sim & Sim & Sim \\
\hline
\end{tabular}

Fonte: Henrique Carlos Parra Parra Filho, 2018.

No caso da $3^{\text {a }}$ Conferência Nacional de Juventude, houve a participação de membros do quadro de servidores de diferentes órgãos e instituições da Administração Pública Federal e também de indivíduos com vínculo transitório, estabelecido apenas para a execução das tarefas decorrentes do caso (consultores contratados), bem como de indivíduos sem quaisquer ligações ou relações diretas com o caso, mas que fazem parte da comunidade do software livre Noosfero e por isso executaram tarefas de apoio aos desenvolvedores, quando estes solicitaram o apoio da comunidade.

As tecnologias escolhidas para o desenvolvimento dos softwares utilizados pela $3^{\mathrm{a}}$ Conferência Nacional de Juventude foram o software livre Noosfero ${ }^{30}$ para a Plataforma da

\footnotetext{
${ }^{24}$ Disponível em: <http://www.cgu.gov.br/assuntos/controlesocial/consocial/arquivos/consocial_resumo_conferencia_virtual.pdf $>$. Acesso em: 14/02/18.

${ }^{25}$ Disponível em: $<$ http://www.cultura.gov.br/banner-1/-/asset publisher/G5fqgiDe7rqz/content/conferenciavirtual-da-iii-cnc/10883>. Acesso em: 14/02/18.

${ }^{26}$ A plataforma foi utilizada para que a população pudesse debater e votar nas propostas que seriam deliberadas pelos delegados na Etapa Nacional. Esta participação não vinculava decisões, mas influenciava indiretamente a opinião e posicionamento dos delegados.

${ }^{27}$ Disponível em: https://undime.org.br/noticia/rede-social-conae2014-facilita-organizacao-de-conferencias-

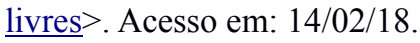

${ }^{28}$ A plataforma foi utilizada para estimular e apoiar a realização de conferências livres (inclusive utilizando o ambiente de rede social para debate de questões). No entanto, nem propostas, nem delegados foram eleitos.

${ }^{29}$ Disponível em: < http://juventude.gov.br/juventude/noticias/vemmudarobrasil-snj-lanca-aplicativo-da-3aconferencia-nacional-de-juventude\#.WIdXe7YrKRs $>$. Acesso em: 14/02/18.

30 Noosfero é uma plataforma web voltado para a criação de redes sociais. A plataforma integra ferramentas como perfil de pessoas, comunidades e empreendimentos, blogs, portfólios online, CMS para sites, RSS, fóruns, chats, eventos e compartilhamento de ideias em um mesmo sistema, além de funcionalidades providas por plugins.
} 
Juventude, e Ionic ${ }^{31} /$ AngularJS $^{32}$ para o aplicativo de celular, que consumia a API $^{33}$ da Porta da Juventude. Ambas serão estudadas por esta pesquisa como um único artefato, não apenas por estarem materializadas como um artefato para os usuários, mas também pelo fato de que a mútua dependência entre backend (Noosfero) e frontend (Ionic/Angularjs) ${ }^{34}$ configuraram efetivamente um artefato percebido e experimentado como único. Dessa forma, será tratado daqui em diante como sendo a tecnologia desenvolvida para a $3^{\text {a }}$. Conferência Nacional de Juventude.

Este artefato possibilitava o cadastro de um perfil (de pessoa ou de uma etapa da Conferência) e a criação, por parte deste perfil, de propostas para debate. Estas propostas deveriam ser escritas com limitação de caracteres, para que fossem mais curtas e possibilitassem fácil leitura pelos demais participantes. Elas também deveriam ser registradas de acordo com eixos temáticos da conferência, facilitando o filtro por parte dos participantes que poderiam votar (apoiar) e comentar nas propostas. Essa colaboração renderia pontos tanto para a proposta (quantidade de apoios e comentários), quanto para os participantes; e as pontuações poderiam ser visualizadas em áreas específicas do aplicativo. Em linhas gerais, a arquitetura de discussão por comentários em conversas dentro de comunidades já fazia parte do Participa.br. Houve o desenvolvimento de algumas funcionalidades específicas para a gameficação (transformação em jogo, por meio da criação de sistema de pontos, medalhas, prêmios simbólicos, perfis), bem como a possibilidade de apoiar as propostas. E todas essas funcionalidades foram apresentadas com uma espécie de "capa", de visual diferente, criado especialmente para a conferência e "empacotado" como um aplicativo para celular.

\footnotetext{
31 Ionic é um framework que usa AngulasJS para criar aplicações com um visual muito similar ao de apps nativos. Oferecendo diversas bibliotecas de CSS e Javascript para AngularJS, ele simplifica o desenvolvimento e ajuda a produzir apps com um visual agradável, sem causar muito trabalho ao desenvolvedor, além de não exigir muito conhecimento prévio, apenas HTML, CSS e Javascript.

32 AngularJS é um framework JavaScript de código aberto, mantido pelo Google, que auxilia na execução de single-page applications. Seu objetivo é aumentar aplicativos que podem ser acessados por um navegador web. Foi construído sob o padrão model-view-view-model (MVVM), em um esforço para facilitar tanto o desenvolvimento quanto o teste dos aplicativos.

33 API provém do Inglês Application Programming Interface, é um conjunto de rotinas e padrões estabelecidos por um software para a utilização das suas funcionalidades por aplicativos que não pretendem envolver-se em detalhes da implementação do software, mas apenas usar seus serviços.

${ }^{34}$ Em ciência da computação, front-end e back-end são termos generalizados que se referem às etapas inicial e final de um processo. $\mathrm{O}$ front-end é responsável por coletar a entrada do usuário em várias formas e processá-la para adequá-la a uma especificação em que o back-end possa utilizar. Em projetos de software, por exemplo, a arquitetura modelo-visão-controlador fornece o front-end e o back-end para o banco de dados, o usuário e para os componentes de processamento. A separação de sistemas de software em front-end e back end simplifica o desenvolvimento e separa a manutenção. Uma regra de ouro é que o lado front (ou "cliente") é qualquer componente manipulado pelo usuário. O código do lado servidor (ou "back-end") reside no servidor.
} 
Esta capa, ou parte visível, foi a aplicação desenvolvida em Ionic/Angularjs e funcionava consumindo a API do Participa.br, espécie de infraestrutura para essa aplicação funcionar. Durante o processo de desenvolvimento da tecnologia usada pela $3^{\text {a }}$ Conferência, houve produção e modificações nas duas partes - no frontend (completamente criado) e no backend. A figura a seguir ilustra esta questão:

Figura 2 - Arquitetura da tecnologia desenvolvida para a 3a. Conferência Nacional de Juventude

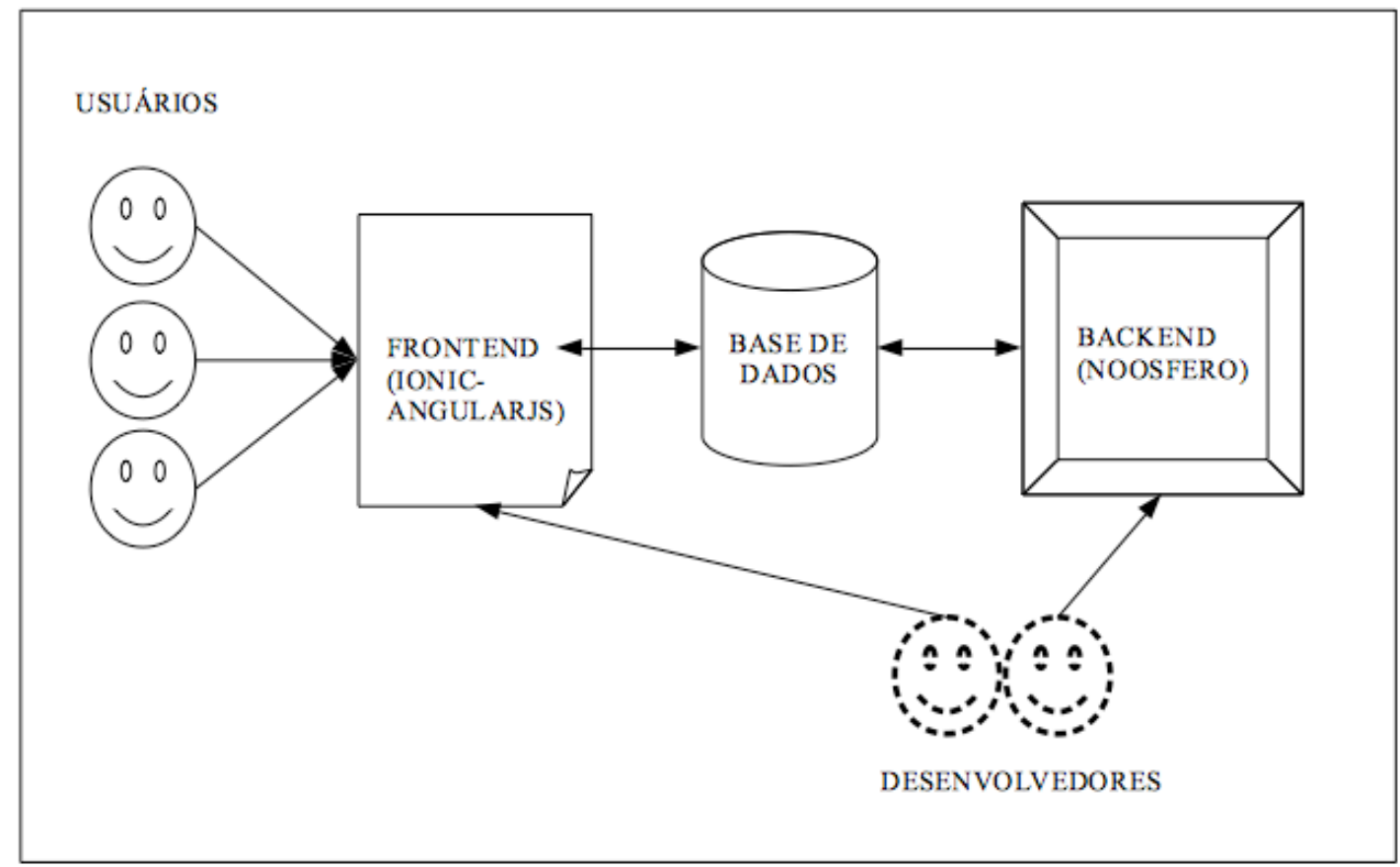

Fonte: Henrique Carlos Parra Parra Filho, 2018.

Para compreender melhor a escolha desta tecnologia, vale destacar que a própria Plataforma de Juventude - principal ferramenta digital utilizada e mantida pela SNJ - foi na verdade migrada para Noosfero. Inicialmente ela havia sido desenvolvida em outra linguagem de programação, no contexto do projeto Participatório ${ }^{35}$ em 2013, mas as dificuldades de manutenção e sustentabilidade fizeram com que a Secretaria Nacional de Juventude decidisse migrar a solução para o Participa.br, plataforma de participação do Governo Federal desenvolvida em Noosfero, e que era mantida a partir de um contrato de desenvolvimento

\footnotetext{
35 O PARTICIPATÓRIO - Observatório Participativo da Juventude foi lançado em 2013 pelo Governo Federal para ser um ambiente virtual interativo com o objetivo de produzir conhecimento sobre/para/pela a juventude brasileira e à participação e mobilização social. Posteriormente migrou para o Participa.Br/ Noosfero como Portal da Juventude.
} 
entre a Presidência da República (através da Secretaria Geral) e o Serpro. O desenvolvimento do Participa.br também contou com a participação de consultores externos mobilizados pela Secretaria Geral. Ricardo Poppi, gestor responsável pela área dentro da Secretaria Geral da Presidência da República, indicou em entrevistas $(2016,2017)$ que o fato do Noosfero ser um software livre desenvolvido e mantido por organizações da sociedade, e que dispõe de uma comunidade de desenvolvedores e usuários constituída, foi um dos principais motivos para sua escolha. Outra razão foi o fato de que o Serpro, empresa pública de tecnologia, também fazia uso do Noosfero para projetos internos, tendo servidores especializados no desenvolvimento do software. Esses dois fatores traduziam a facilidade de contar com múltiplos fornecedores e desenvolvedores para o desenvolvimento do software, bem como a possibilidade de que seu aperfeiçoamento também fosse mantido por estas outras organizações (para seus próprios objetivos e projetos), trazendo benefícios contínuos para a Administração Pública Federal sem a necessidade de novas contratações ou compras.

A facilidade em aderir a este arranjo de desenvolvimento do Noosfero - pois a Presidência já tinha contrato estabelecido com o Serpro - e os ganhos de sustentabilidade já mencionados fizeram com que a SNJ decidisse pela migração de sua plataforma, adotando o Noosfero também. Este era o cenário quando do início dos preparativos para a $3^{\text {a }}$ Conferência Nacional de Juventude.

No entanto, a SNJ via a necessidade de implementar com rapidez, pelos prazos e dinâmica da Conferência, funcionalidades novas e uma experiência inovadora de uso da tecnologia. Além da necessidade de uma solução desenhada para uso em celulares, havia a necessidade de construir um processo gameficado no qual os participantes fossem ganhando pontos e estímulos para criar propostas, comentar e votar nas propostas dos demais, estimulando a deliberação característica dos processos conferenciais. Algumas destas funcionalidades já existiam no Noosfero, mas outras ainda precisariam ser desenvolvidas.

A escolha da Secretaria Nacional de Juventude foi de constituir uma equipe híbrida de desenvolvimento, mobilizando consultores externos por meio do instrumento de consultoria vinculada a acordos de cooperação técnica internacional e utilizando o contrato da Presidência da República com o Serpro, que já destinava algum recurso para a manutenção do Portal da Juventude. Esse contrato já definia quantidade determinada de pontos de função, e o objetivo da SNJ era que uma parte destes pontos fossem utilizados para o desenvolvimento da tecnologia da Conferência. Dessa forma, não haveria a necessidade de um processo de 
contratação novo ou específico. Além disso, na perspectiva da manutenção desta tecnologia, o relacionamento com o Serpro ofereceria as facilidades de contratação desta empresa pública (dispensa de contratação), de seu histórico com desenvolvimento e utilização do software Noosfero e de a Administração Pública Federal ter outros projetos que utilizavam o software (Participa.br, Portal do Software Público e o Dialoga Brasil sendo iniciado), o que significava a existência de melhorias e atualizações que também poderiam beneficiar os usos da SNJ.

Para isso, a Secretaria Nacional de Juventude precisaria construir um acordo político dentro da Secretaria Geral da Presidência da República, com o objetivo de que a Presidência direcionasse certa quantidade dos pontos de função do contrato estabelecido com o Serpro para o desenvolvimento da tecnologia da Conferência. Esse acordo foi realizado, embora tenha havido mudança posterior que será detalhada ainda neste capítulo. Cabe antes apresentar o que é um Ponto de Função. Trata-se de uma medida usada para controle em contratos de desenvolvimento de software, com o objetivo de possibilitar o controle e a verificação sobre o que foi contratado e o que foi efetivamente entregue. É uma medida independente da linguagem de programação ou da tecnologia escolhida e tem sido amplamente utilizada pela Administração Pública Federal.

O Ponto de Função é utilizado para medir a dimensão do trabalho que será necessário para o desenvolvimento das soluções e funcionalidades demandadas, de modo a estimar o tempo e o custo, de maneira global e também detalhada (possibilitando inclusive indicar a quantidade de pontos de função para cada funcionalidade, por exemplo). A partir daí, a entrega de tais funcionalidades e soluções possibilitam a remuneração dos pontos de função nelas contidos. Em outras palavras, é um mecanismo para estimar custos e recursos envolvidos em projetos de desenvolvimento e manutenção de software e para viabilizar o controle das entregas.

Outro instrumento que tem sido utilizado para o desenvolvimento de softwares, em especial para soluções inovadoras, é o de consultoria vinculada a acordos de cooperação técnica e internacional, celebrados entre entidades públicas federais e organismos internacionais. Esse tipo de acordo de cooperação técnica e internacional entre entidades públicas federais (seja da administração direta ou indireta) e organismos internacionais, como a UNESCO, PNUD, OEI, etc, tem o objetivo de fortalecer políticas públicas do Governo 
Federal, facilitando a mobilização de pessoal especializado por parte dos órgãos públicos. ${ }^{36}$ No caso brasileiro, acordos de tal natureza não podem ser mecanismos para autorizar a contratação de serviços cuja execução possa ser realizada por seus próprios servidores, devendo se ocupar da transferência de conhecimento por parte do organismo internacional. Tampouco devem ser empregados em cenários cujo assunto e cuja prática sejam de domínio público, pois são demandados rotineiramente pela Administração e estão disponíveis no mercado - sendo a contração de bens e serviços de natureza comum apropriada para essas circunstâncias. Tal foi o instrumento utilizado no desenvolvimento da tecnologia utilizada pela $3^{\text {a }}$ Conferência Nacional de Juventude.

Aliando as necessidades de sustentabilidade e de inovação, a SNJ optou por mesclar a atuação do Serpro (via contratação já existente da Presidência da República e que adota o Ponto de Função como métrica) com a mobilização de uma equipe de consultores externos. Além disso, a própria equipe da Secretaria Nacional de Juventude participou do processo de especificação e acompanhamento, bem como Ricardo Poppi da Secretaria Nacional de Articulação Social (SNAS) e de servidores da Diretoria de Tecnologia (DITEC). Estes dois órgãos são vinculados à Presidência da República (PR), assim como a SNJ.

A Diretoria de Tecnologia tem como uma de suas atribuições acompanhar os contratos de desenvolvimento de software no âmbito da Presidência da República e participar verificando a entrega das funcionalidades demandadas ao Serpro, validando com os pedidos iniciais realizados. Se por um lado a SNJ apresentava as funcionalidades demandadas e o Serpro estimava a quantidade de pontos de função necessários para seu desenvolvimento, a DITEC validava a entrega com a SNJ e a entrega do ponto de vista contratual.

Já a atuação da SNAS, mais especificamente da Coordenação de Novas Mídias no projeto da $3^{\text {a }}$ Conferência Nacional de Juventude, ia de encontro com seus objetivos políticos e institucionais, mas viabilizava-se por um acordo político de colaboração já que não se tratava de uma atribuição da coordenação ou mesmo da SNAS. A Coordenação naquele momento tinha a atribuição institucional de liderar os projetos de participação social que

\footnotetext{
${ }_{36}$ O Tribunal de Contas da União (TCU) já debateu este instrumento, como nos mostra o voto do Ministro Relator José Jorge, no Acórdão TCU n 1.339/2009 - Plenário: “(...) os propósitos dos projetos de cooperação técnica estão restritos às hipóteses nas quais haja transferência de conhecimentos ou exista assessoria técnica, a qual, por seu turno, deve compreender atividades de treinamento, consultoria, bem como a aquisição de bens e contratação de serviços, desde que estes estejam vinculados ao desenvolvimento das ações contidas no acordo básico de cooperação e que não possam ser executadas pelo próprio órgão pertencente à administração pública federal.” (TCU, 2009, s.p.)
} 
envolvessem o uso de TICs por parte da Secretaria Geral da Presidência da República, o que se traduzia particularmente no desenvolvimento e manutenção do Participa.br.

O portal já vinha oferecendo uma série de funcionalidades e serviços ao conjunto de órgãos da Administração Pública Federal, que realizavam consultas públicas e processos de diálogo e escuta utilizando a ferramenta, sem o ônus de terem de realizar o desenvolvimento de soluções próprias. A própria equipe da SNAS ofereceria suporte (limitado) para curadoria e para o planejamento dos processos, estimulando a apropriação por parte dos órgãos e gestores. Além dessa atuação e das consultas de interesse da Secretaria Geral, a coordenação também iniciou o projeto Dialoga Brasil, realizado pela própria Presidência da República, que utilizou o Participa.br e criou uma aplicação específica, para debater os programas de governo (Bolsa Família, Ciência Sem Fronteiras, Minha Casa Minha Vida, Pronatec, etc) e receber ideias de melhoria por parte dos cidadãos interessados. Eles poderiam sugerir melhorias e votar nas melhorias que preferissem; e as ideias mais votadas receberiam resposta oficial do governo ao final. Durante o processo, ministros e ministras realizariam debates online para comentar as principais ideias que surgissem na plataforma.

A menção do Dialoga Brasil se faz importante pois seu desenvolvimento se baseou em arranjo semelhante àquele escolhido pela SNJ, ou seja, ambas as aplicações foram desenvolvidas em Noosfero, a partir do Participa.br. Ambas utilizariam o contrato em vigência com o Serpro. No entanto, a centralidade política do Dialoga Brasil (projeto que era tocado diretamente pela equipe da Presidenta e da chefia da Secretaria Geral da Presidência da República) e a crescente complexidade de sua aplicação fizeram com que seu desenvolvimento demandasse praticamente todo o contrato, ou seja, todos os pontos de função disponíveis.

Essa dinâmica se desdobrou ao longo dos projetos, cujas tecnologias foram desenvolvidas praticamente no mesmo momento. A crescente demanda do Dialoga Brasil foi alterando a capacidade de uso dos pontos de função por parte da SNJ, ou seja, foi reduzindo a capacidade de atendimento por parte do Serpro. A questão não era financeira, ou seja, um aditivo deste contrato para aumentar a quantidade de pontos de função não era uma alternativa. A questão era priorizar a força de trabalho do Serpro que fosse especializada em Noosfero para atender ao Dialoga Brasil.

Essa mudança já na fase de implementação, ou seja, depois de tomada a decisão pelos instrumentos de contratação específicos e já com o início das atividades dos primeiros 
consultores mobilizados, significava a necessidade de uma alternativa com alguma urgência. Se inicialmente a equipe do Serpro cuidaria do desenvolvimento backend e os consultores do frontend e da usabilidade, agora era necessário mobilizar alguma equipe para o backend, sob risco de não entregar a tecnologia a tempo. Um programador frontend é aquele que cuida de tudo o que é relativo à interação com o usuário; já o programador de backend desenvolve o sistema que vai ser utilizado para gestão dos dados e utilizará a interface desenvolvida pelo frontend. Em outras palavras, o projeto não poderia prosseguir sem alguma equipe responsável pelo desenvolvimento backend.

Pela agilidade, a SNJ optou por mobilizar mais consultores externos. Em primeiro lugar isso se deveu ao fato de o convênio com o organismo internacional estar em vigor, o que facilitaria e aceleraria todo o processo (mesmo que abrindo novos editais); depois, pelo processo ser mais simples e ágil do que um processo licitatório. Por fim, a agilidade era necessária não apenas no processo de contratação, mas nas entregas quase imediatas que a nova equipe deveria fazer; e a SNJ entendia que o instrumento de consultoria possibilitaria mobilizar membros já experientes na comunidade Noosfero e mesmo que já tivessem se envolvido em projetos semelhantes ao seu. Esses critérios poderiam ser indicados no edital de seleção de consultores e a mobilização de uma equipe com experiência poderia acelerar as entregas necessárias. Como veremos, estes objetivos foram alcançados.

Foram descritas até o momento a atuação da Secretaria Nacional de Juventude, líder do projeto e responsável por demandar, especificar e monitorar o desenvolvimento das funcionalidades e da tecnologia. Esse acompanhamento era realizado pela SNJ que comparava as entregas com os pedidos realizados. Se era necessário, por exemplo, ter um cadastro com determinadas informações sobre os participantes e possibilitar que eles utilizassem suas contas de Facebook e Twitter para acessar o aplicativo, a equipe do projeto discutia tais necessidades, especificava tecnicamente e apresentava as funcionalidades que seriam desenvolvidas (no caso específico do Serpro isso incluía dizer quantos pontos de função seriam necessários para executar as tarefas). Por fim, a avaliação era se efetivamente os participantes conseguiriam fazer seu acesso utilizando contas de redes sociais e se o resultado era um banco de dados dos cadastrados.

Também foram descritas a atuação da Coordenação Geral de Novas Mídias, que integrava a SNAS, e a da Diretoria de Tecnologia, a DITEC. E foi possível apresentar a maneira como o Serpro atuou ao longo do projeto; assim como foi esclarecido o papel dos 
consultores externos, mobilizados pela SNJ através de editais em convênio com organismo internacional. Essas relações ficam visíveis na Figura 3:

Figura 3 - Relações entre organizações envolvidas na coprodução da tecnologia utilizada na $3^{\text {a }}$ Conferência Nacional de Juventude

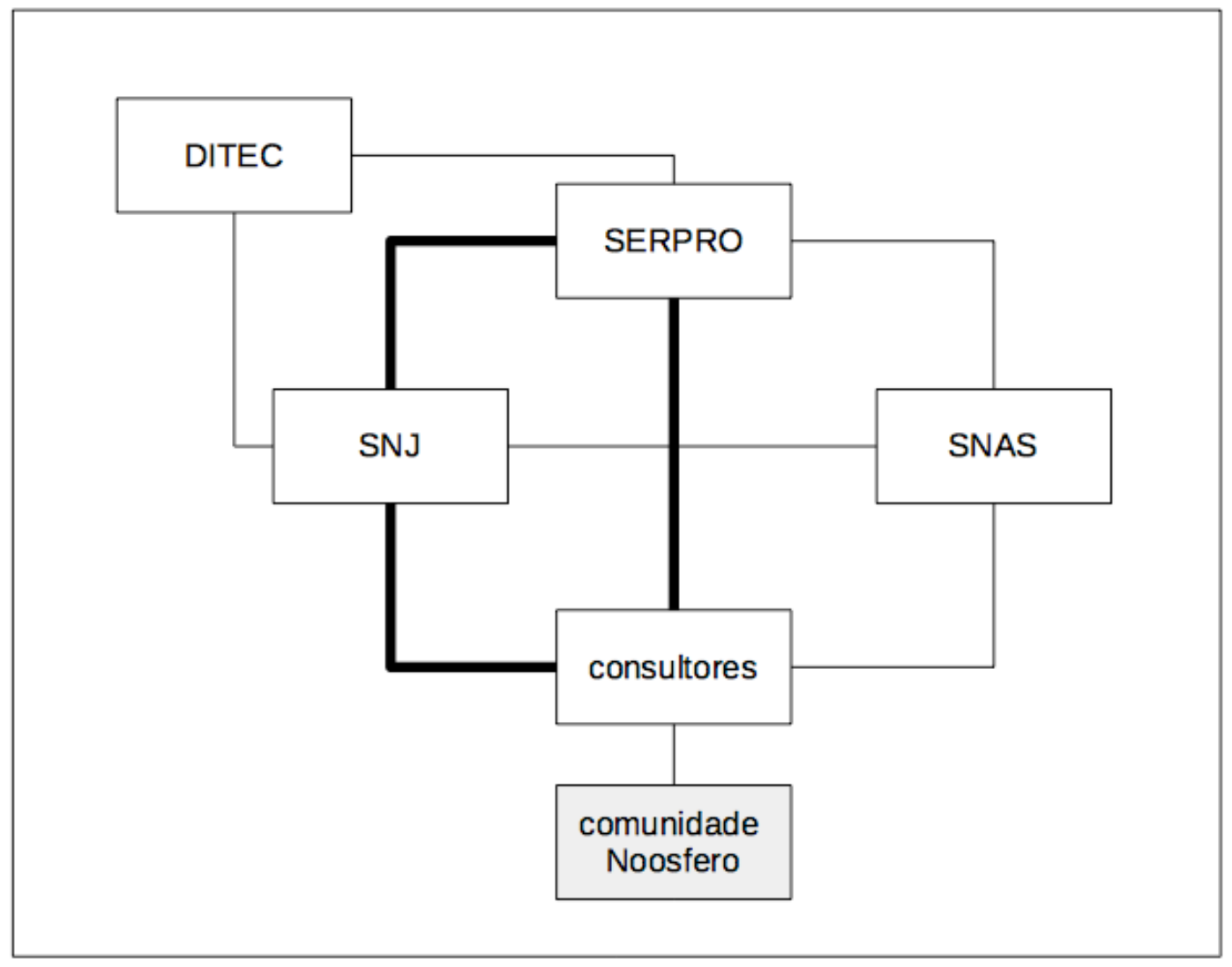

Fonte: Henrique Carlos Parra Parra Filho, 2018.

As interações mais recorrentes foram entre a SNJ e o grupo de consultores, entre a SNJ e o Serpro e entre a equipe de consultores e o Serpro, por isso estão assinaladas na figura acima por uma linha mais espessa. Mesmo depois que o Serpro reduziu sua atuação no projeto, desenvolvendo menos e alocando poucos pontos de função, essa interação se manteve. Como é ressaltado pelos entrevistados (Caio Sacramento, 2016, 2017; Leandro Nunes, 2017; e Ricardo Poppi, 2016 e 2017) o Serpro desempenhou um papel importante de orientação dos consultores, de aconselhamento e assessoramento sobre seu trabalho e de revisão sobre o que era produzido pelos consultores. Esse papel se assemelha àquele desempenhado por indivíduos pertencentes à Comunidade Noosfero e que, mesmo sem 
nenhum tipo de vínculo direto ou indireto com o projeto ou com alguma de suas organizações, também desempenhavam estas atividades de orientação, assessoria e revisão.

Segundo os mesmos entrevistados (além de Marcos Ronaldo, 2017 e Hugo Melo, 2017) esse papel é rotineiro e comum nas comunidades de software livre. Quando há o desenvolvimento de novas funcionalidades por algum indivíduo ou organização, outros membros avaliam de que maneira aquela funcionalidade pode agregar valor aos usos que faz do software ou aos benefícios de reputação que a colaboração pode gerar, por exemplo. Motivações como essa, bem como uma espécie de compromisso e solidariedade mútua entre os membros de algumas comunidades de software livre explicam a colaboração mesmo sem benefícios econômicos diretos (na transação).

Em outras palavras, as melhorias em um artefato utilizado de maneira comum, o ganho de reputação por conhecer e se envolver ao máximo no código e a colaboração mútua para estimular uma comunidade com mais participantes que desenvolvam melhorias são algumas das razões que motivam a ação da comunidade. O próprio caso do Serpro exemplifica bem esta relação entre os projetos de uma comunidade. No projeto da $3^{\text {a }}$ Conferência Nacional de Juventude, o Serpro efetivamente utilizou pontos de função para realizar entregas demandadas pela SNJ.

Mas além disso, a entrevista feita com Leandro Nunes (2017), servidor do Serpro, deixa claro seu papel desempenhado, como membro atuante na comunidade Noosfero para aconselhar, tirar dúvidas e auxiliar os consultores da equipe da SNJ. Esse trabalho não encontra possibilidade de remuneração pelo instrumento de ponto de função e, portanto, não configura uma atividade correspondente ao contrato entre Serpro e Presidência da República. No entanto, é uma atividade cujo objeto (desenvolvimento do backend do Participa.br) é o mesmo da prestação de serviços do Serpro para a SNJ e também do desenvolvimento do Dialoga Brasil. Ou seja, o sucesso das atividades desenvolvidas pelos consultores em relação a este objeto tem impacto no mesmo objeto de atividade do Serpro. Mais do que isso, pode gerar benefícios a serem utilizados nos projetos e mesmo acelerar o desenvolvimento de funcionalidades comuns a eles.

Recorrendo mais uma vez à SCOT (Construção Social da Tecnologia), cabe assinalar que ter um papel de destaque em uma comunidade que produz determinada tecnologia pode garantir poder de influência no debate sobre os distintos problemas e soluções percebidos e na decisão de quais problemas são definidos como prioritários e quais soluções são as mais 
adequadas. Isso ocorre porque há uma flexibilidade interpretativa no processo de construção de tecnologias, ou seja, cada artefato tecnológico tem diferentes significados e interpretações entre grupos diversos. Distintos problemas são percebidos e um mesmo fenômeno pode ter interpretações alternativas, dando origem a conflitos que podem ser resolvidos através da negociação entre os grupos ou motivar a produção de soluções distintas e independentes.

Diferentes grupos podem priorizar problemas distintos, levando a diferentes projetos. No entanto, ao longo do tempo, esta flexibilidade de interpretações e as estruturas tecnológicas desenvolvidas nas soluções costumam convergir e se estabilizar, influenciados justamente pela aceitação, uso e competição (bem como por consensos entre os produtores). São mecanismos de fechamento que definem qual estrutura tecnológica emergirá de fato na utilização. Ocupar um papel de destaque em uma comunidade de software, revisando e contribuindo sobre a produção de outros indivíduos constitui influência no processo de convergência e estabilização (mecanismo de fechamento) das tecnologias.

Ainda no esforço de compreender todas as interações que influenciaram o processo de desenvolvimento da tecnologia da $3^{\text {a }}$ Conferência Nacional de Juventude, vale observar que especialmente no início do processo houve a participação de atores mais políticos (gestão da SNJ e membros da CON), debatendo a proposta inicial apresentada pela equipe técnica. Essa deliberação (que ocorreu ao longo de todo o desenvolvimento) era processada pela SNJ e se apresentava durante os debates e decisões da equipe através de Carla Bezerra, que acompanhou todo o processo de especificação e avaliação das entregas. Além de sua presença pela SNJ, houve ainda a participação de Ricardo Poppi, da SNAS, que apoiou a mobilização de consultores e a especificação técnica das funcionalidades (acompanhando as reuniões com a equipe de desenvolvimento, que traduzia as demandas em especificações técnicas e discutia as alternativas e escolhas de desenvolvimento). Já a DITEC acompanhou a entrega por parte do Serpro.

O Serpro, na figura de Leandro Nunes, também participava das reuniões em que as demandas e funcionalidades desejadas eram especificadas tecnicamente e nas quais eram avaliadas as possibilidades e alternativas de desenvolvimento. Além de terem desenvolvido e entregado algumas destas funcionalidades diretamente, houve ainda o acompanhamento e a revisão delas, quando solicitados pelos consultores, pelo fato de Leandro ter grande experiência em Noosfero e um papel de destaque na comunidade. Essa comunidade, através de seus membros, também ofereceu apoio no aconselhamento e revisão, sempre a pedido 
direto dos consultores, em um tipo de atividade rotineira e comum nestas comunidades, conforme destacam Hugo Melo (2017), Marcos Ronaldo (2017) e Caio Sacramento (2016; 2017) em suas entrevistas. A equipe de consultores que se ocupou da tecnologia se concentrou na programação do software através de Caio Sacramento, Fabiano Rangel, Hugo Melo e Marcos Ronaldo. Os dois últimos integraram a equipe para atuar no backend, assim que o Serpro se concentrou no desenvolvimento do Dialoga Brasil e encontrou limitações para seguir com o projeto da Conferência de Juventude. Chama a atenção o fato de que, em um projeto da SNJ, SNAS, Serpro e o time de consultores tenha estabelecido relações mútuas, diretamente, com uma série de interações entre consultores-Serpro e consultores-SerproSNAS. Em outras palavras, havia certa autonomia nas relações estabelecidas, todas dentro do marco do projeto da $3^{\text {a }}$ Conferência Nacional de Juventude e com a finalidade de desenvolver as funcionalidades e a tecnologia demandadas.

O fato de a SNAS ter grande experiência na gestão de projetos em Noosfero e estar, naquele momento, atuando no Dialoga Brasil e o fato de o SERPRO reunir estas mesmas qualificações, além de contar com servidores com grande experiência em Noosfero e relevância em sua comunidade fez com que estas relações e interações acontecessem de maneira bastante orgânica.

\subsection{HiSTÓRICO DE CONSTRUÇÃO DO NOOSFERO}

O software livre Noosfero é peça chave para a investigação sobre a tecnologia desenvolvida para a $3^{\text {a }}$ Conferência Nacional de Juventude. Desta feita, buscou-se recuperar seu histórico de desenvolvimento.

O Noosfero é uma plataforma web voltada para a criação de redes sociais, possibilitando a criação de blogs, áreas de discussão e agenda de eventos; e permitindo aos usuários criarem perfil de pessoas, comunidades e empreendimentos. Também oferece $\mathrm{RSS}^{37}$, $\mathrm{CMS}^{38}$ para sites, fóruns, chats; e foi desenvolvido com uma forte estratégia de criação de

\footnotetext{
${ }_{37}$ RSS é um subconjunto de "dialetos" XML que servem para agregar conteúdo ou "Web syndication", podendo ser acessado mediante programas ou sites agregadores. É usado principalmente em sites de notícias e blogs.A tecnologia do RSS permite aos usuários da internet se inscreverem em sites que fornecem "feeds" RSS. Estes são tipicamente sites que mudam ou atualizam o seu conteúdo regularmente. Para isso, são utilizados Feeds RSS que recebem estas atualizações, desta maneira o utilizador pode permanecer informado de diversas atualizações em diversos sites sem precisar visitá-los um a um.

${ }^{38}$ Sistema de Gerenciamento de Conteúdo (do inglês Content Management System - CMS) é um aplicativo usado para criar, editar, gerenciar e publicar conteúdo de forma consistentemente organizada permitindo que o mesmo seja modificado, removido e adicionado com facilidade. CMSs são frequentemente usados para armazenar, controlar, prover documentação empresarial tal como notícias, artigos, manuais de operação, manuais
} 
comunidade, contando com desenvolvedores espalhados pelo mundo, o que garante o lançamento de novas versões frequentemente. Foi desenvolvido em 2009 pela Colivre, a Cooperativa de Trabalho em Tecnologias Livres, uma cooperativa formada em Salvador com o objetivo de contribuir para a difusão e o desenvolvimento de tecnologias livres por meio de soluções oferecidas a empresas, organizações da sociedade civil, órgãos públicos e Instituições de ensino.

A Colivre mantém um forte relacionamento com organizações que atuam com Economia Solidária, exatamente o contexto do primeiro uso de maior relevância do software, o Cirandas.net, iniciativa do Fórum Brasileiro de Economia Solidária para promover a articulação econômica, social e política de quem aprecia Economia Solidária ou vive dela através de ferramentas digitais e da internet. O Fórum adotou o Noosfero e estabeleceu parceria com a Colivre desde então. Os principais usos da plataforma tiveram como objetivo potencializar o fluxo de saberes, dos produtos e dos serviços das organizações e de indivíduos deste campo, buscando estabelecer redes e cadeias solidárias. Na plataforma os participantes podem divulgar seus produtos e atividades e interagir entre si.

Desde o final de 2010, o Noosfero passou a ser usado por pesquisadores do Centro de Competência em Software (CCSL-USP) e foi adaptado para ter uma infraestrutura de plugins, ou seja, preparou o Noosfero para receber uma série de novas funcionalidades e melhorias específicas que pudessem ser habilitadas ou desabilitadas porcada usuário, mantendo o software flexível aos objetivos e usos da diversidade de organizações e indíviuod que usassem ou viessem a utilizar o software. Em seguida, outro uso do Noosfero na USP foi a implantação da rede social do QualiPSo (Quality Platform for Open Source Software), projeto da Comissão Europeia para promover e estimular o uso de software livre na indústria que acabou envolvendo centros de competência em software livre de oito países. Trata-se de mais um exemplo dos benefícios do uso e do desenvolvimento de software livre; pois neste projeto houve a implementação dos fóruns de discussão, funcionalidade que foi disponibilizada para todos que usavam ou viriam a usar o Noosfero.

Já no primeiro semestre de 2011, o Noosfero foi analisado (assim como outras plataformas livres como o Elgg e Buddypress) por uma equipe formada por estudantes e professores da USP com o objetivo de definir qual seria a tecnologia escolhida para o documentos e conteúdo Web. Um CMS permite que a empresa tenha total autonomia sobre o conteúdo e evolução da sua presença na internet e dispense a assistência de terceiros ou empresas especializadas para manutenções de rotina. 
desenvolvimento da rede social da Universidade, posteriormente chamada de Stoa. O resultado dessa investigação foi a escolha pelo Noosfero, baseada especialmente em quatro fatores: 1. o software já tinha as funcionalidades necessárias para um projeto como o Stoa (lembrando que o foco do Noosfero é justamente o de funcionar como rede social); 2. pesava a seu favor o fato de ele já ser utilizado, então, em projetos da USP; 3. o Noosfero tinha uma comunidade estabelecida de desenvolvedores de outros projetos em curso, que potencialmente produziriam melhorias que viriam a beneficiar os projetos da USP (quando uma melhoria é desenvolvida em software livre e incorporada pelos membros da comunidade); 4. e por fim, dispunha de licenças que possibilitavam apropriação tecnológica e era conduzido por uma organização que prioriza tal apropriação, dando suporte para a formação de comunidade.

Na Esfera Governamental, o Noosfero faz parte de plataformas como Participa.br, Portal da Juventude, Portal do Software Público Brasileiro, Você.MJ, Colabora.gov.br e Dialoga Brasil. E o fato de o Serpro, empresa pública de desenvolvimento de softwares, já utilizar o Noosfero e ter equipe especializada constitui fator decisivo para entender esta adesão. Em 2012 o Serpro criou uma rede social corporativa utilizando Noosfero com o objetivo de criar um ambiente de troca de experiência entre todos os funcionários da organização no país. Nele, o empregado da empresa pode encontrar especialistas em determinados assuntos e interagir diretamente com estes via mensageiro instantâneo. Outro uso dessa plataforma é a possibilidade de os usuários criarem criar grupos e realizar troca de experiências (o Serpro estimula a troca de informações relacionadas aos objetivos e atividades profissionais, como capacitação contínua). Além disso, o espaço poderia ser utilizado para debater assuntos vistos como relevantes pelo conjunto de empregados, fortalecendo o processo de diálogo e governança.

Vale destacar ainda, a partir da entrevista com Leandro Nunes (2017), que o Noosfero não é homologado ${ }^{39}$ no Serpro, ainda que seja uma tecnologia utilizada internamente e que também integre a carteira de projetos e de prestação de serviços oferecidos pela empresa. Sua escolha pode ter levado em consideração questões técnicas e funcionais e, embora não seja o objeto desta investigação, pode em alguma medida também ter sido influenciada por outras questões como o fato de ter grande reputação na comunidade brasileira de software livre.

39 A homolgação significa que todos os trâmites necessários para a tecnologia ser considerada oficial pelo Serpro foram cumpridos e a tecnologia foi internalizada. O Processo do Ciclo de Vida de Tecnologia da Informação e Comunicação do Serpro (PCVTIC) possui cinco fases: análise, prospecção, internalização, sustentação e declínio e a homolgação ocorre durante a internalização. 
Para esta investigação, o fato relevante é que a empresa pública adotou e passou a se especializar neste software, motivo apresentado por Ricardo Poppi (em entrevistas, 2016, 2017) como um dos elementos centrais que levaram a Secretaria Geral da Presidência da República a adotar o Noosfero para o desenvolvimento do Participa.br e os decorrentes ganhos de sustentabilidade foram apontados pelo mesmo entrevistado (POPPI, 2016, 2017) e por Carla Bezerra (2017) como fatores determinantes para a migração do Portal da Juventude também para o Noosfero, motivo que depois explica as decisões de desenvolvimento da tecnologia utilizada pela $3^{\text {a }}$ Conferência Nacional de Juventude.

A maturidade do software (iniciado em 2009 e com cerca de seis anos quando da realização da Conferência) e a constituição de uma forte comunidade de desenvolvedores em distintas organizações (Serpro, USP, Colivre e UnB, para citar alguns exemplos) e em diferentes campos (administração pública, economia solidária, universidades) construíram um valor potencial de benefício, a partir de melhorias produzidas por estas diferentes organizações - benefício que é levado em consideração por uma organização ou um indivíduo que decide adotar o software.

Considerando ainda que a mobilização do Serpro por órgãos da Administração Pública Federal conta com vantagens comparativas (como o fato de poder dispensar licitação), e que diversos órgãos ou já têm contratos em vigência ou têm o histórico de ter contratado do Serpro, as facilidades administrativas também acabam por constituir estímulo para a adesão a softwares oferecidos pelo Serpro, como é o caso do Noosfero.

A adesão por diversos órgãos (bem como pelo próprio Serpro) não significou deixar de utilizar outros instrumentos de contratação. Como é apresentado nesta pesquisa, o desenvolvimento da tecnologia para a $3^{\text {a }}$ Conferência Nacional de Juventude se assentou em um arranjo híbrido, que envolvia o Serpro e a mobilização de consultores externos. O desenvolvimento do Participa.br também mobilizou consultores; e o desenvolvimento do Portal do Software Público Brasileiro, em Noosfero, foi realizado através da mobilização de laboratório de software livre da Universidade de Brasília. Inclusive o fato de existirem diversos projetos e organizações utilizando o Noosfero facilita a mobilização de consultores externos, pois há diversos profissionais especializados ou com domínio sobre este artefato que podem ser contratados pelo instrumento de consultoria. A existência de laboratórios de software em Universidades Públicas também oferece a possibilidade do uso de instrumentos específicos (no caso da UnB, o uso do Termo de Descentralização de Recursos, por exemplo). 
Como já foi dito, a soma destes projetos governamentais justificou um fork ${ }^{40}$ do Noosfero, chamado de Noosfero Gov, o que acabou por estimular a interação entre eles em busca de otimização dos esforços de desenvolvimento e a tomada de decisão sobre os caminhos da tecnologia. Esse instrumento do fork é relevante quando se pensa na adesão da Administração Pública aos softwares livres pois evidencia as possibilidades de autonomia e controle sobre o artefato. Em outras palavras, mesmo que tenha aderido a um software livre cuja comunidade toma decisões sobre as novas funcionalidades e sobre a versão comum do artefato, a Administração Pública pode manter uma versão autônoma, sobre a qual mantém poder de decisão e controle, escolhendo ainda quais melhorias produzidas pela comunidade quer, ou não, incorporar.

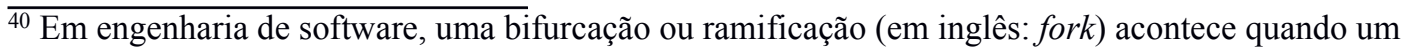
desenvolvedor (ou um grupo de desenvolvedores) inicia um projeto independente com base no código de um projeto já existente, ou seja, quando um software é desenvolvido com base em outro, já existente, sem a descontinuidade deste último. O termo é particularmente usado no software livre ou de código aberto, quando uma divisão ocorre por causa de diferentes objetivos.
} 


\section{DisCUSSÃo}

Como já foi apresentado, o balanço das entrevistas realizadas sistematizou 219 unidades de análise, classificadas de acordo com as onze subcategorias que compõem o conceito de Capacidades de Governo Relacionadas à Utilização de TICs em Processos de Participação Social (CGTPS) proposto por Stefani (2015). Neste capítulo será realizada uma discussão sobre estas subcategorias à luz da investigação empreendida, destacando a mobilização de capacidades estatais para a produção da tecnologia utilizada pela $3^{a}$ Conferência Nacional de Juventude.

\subsection{CAPACIDADES TÉCNICAS}

A dimensão técnica das capacidades estatais é aquela vinculada a funções que envolvam o domínio de técnicas e tecnologias específicas. Dentre os vários aspectos técnicos pertinentes à utilização de TICs em processos participativos apontados por Anita Stefani (2015), em sua classificação quatro elementos se destacaram como subcategorias: Recursos Humanos; Recursos Financeiros e Físicos; Tecnologia; e Gestão do Processo Participativo.

\subsubsection{Recursos Humanos}

Tal dimensão diz respeito à disponibilidade e à qualidade de recursos humanos envolvidos no processo de utilização de TICs em participação social. Ou seja, toma-se em consideração se a equipe envolvida era composta por pessoas qualificadas e apropriadas a respeito do gerenciamento e desenvolvimento da consulta (incluindo a questão tecnológica e metodológica), bem como por pessoas familiarizadas com o assunto-objeto para o qual se pretende contar com a participação social (tema-objeto da política pública em questão).

No momento de planejamento da $3^{\text {a }}$ Conferência Nacional de Juventude, explicitaramse os indicativos políticos de uso de novas metodologias e de envolvimento de jovens para além dos grupos ligados a partidos e movimentos políticos, indicativos presentes nos debates das conferências anteriores, do Conselho Nacional e, em especial, no projeto político da nova gestão à frente da Secretaria Nacional de Juventude (conforme entrevistas com Gabriel Medina, 2017, Tamara Terso, 2017 e Carla Bezerra, 2017, apontam).A busca de soluções 
digitais foi aventada neste momento, quando se estudaram as possibilidades do uso do Portal da Juventude (tecnologia já então existente). A limitação apresentada pelas funcionalidades do Portal, no entanto, demonstraram a necessidade de um desenvolvimento complementar e mais específico, adaptando a tecnologia à dinâmica das Conferências Nacionais, com seus diferentes tipos de etapas, e contemplando a necessidade de eleição de propostas e delegados.

Além de uma equipe de servidores e gestores bastante enxuta, a Secretaria Nacional de Juventude (SNJ) não contava com nenhum especialista em engenharia de software ou programação em seus quadros. A rigor, todo o recurso humano deveria ser mobilizado a partir daquele momento; e além de uma especificação mínima sobre qual tecnologia deveria ser desenvolvida e qual o tamanho e as características da equipe necessária, também era necessário se cercar de especialistas capazes de desenhar essa especificação e orientar o processo. Não havendo nenhum gestor com essas características na Secretaria Nacional de Juventude, buscou-se apoio na Coordenação Geral de Novas Mídas da Secretaria Nacional de Articulação Social (SNAS), que também fazia parte da Secretaria Geral da Presidência da República, assim como a SNJ.

A consulta à SNAS foi um caminho complementar aos diálogos já estabelecidos com o Serpro, que atendia a SNJ através de contrato firmado com a Secretaria Geral da Presidência da República, hospedando e dando suporte de manutenção para o Participa.br, plataforma onde o Portal da Juventude estava sediado. Assim, o envolvimento da SNAS via Ricardo Poppi neste processo de planejamento e especificação que baseou as escolhas de tecnologia e formação de equipe de desenvolvimento é, em si, a mobilização de um recurso humano externo à SNJ, porém interno à SGPR. Além da experiência em Noosfero (Participa.br e migração do Portal da Juventude), Ricardo Poppi também tinha envolvimento em algumas das principais consultas públicas que utilizaram TICs pelo Governo Federal, além de ter experiência no desenvolvimento de tecnologias com o Serpro e com consultores externos.

Nesse momento, as necessidades de inovação tecnológica para dar conta das exigências da $3^{\text {a }}$ Conferência Nacional de Juventude e o prazo bastante curto para as entregas iniciais fizeram com que a SNJ decidisse por um arranjo híbrido, recorrendo ao mesmo tempo ao Serpro e a consultores externos. De fato, ao longo do processo, houve o envolvimento direto de cinco consultores externos na programação e no desenvolvimento tecnológico (Luciano Santa Brígida, Caio Sacramento, Fabiano Rangel, Marcos Ronaldo e Hugo Melo, 
havendo desistência do primeiro deles). Como foi apresentado no Capítulo 4, o envolvimento do Serpro foi mais pontual, por motivos que serão aprofundados neste capítulo.

Além dessa equipe e do debate político ampliado que definia diretrizes gerais e também algumas orientações para guiar o desenvolvimento tecnológico, os debates sobre os rumos de desenvolvimento envolveram de maneira mais direta outros consultores externos: a DITEC, Ricardo Poppi pela SNAS e Carla Bezerra, gestora responsável pelo processo como um todo. Assim, quase a totalidade dos recursos humanos envolvida diretamente no desenvolvimento das tecnológicas foi composta por consultores externos, mobilizados especificamente para a iniciativa da Conferência por meio de acordos de cooperação técnica internacional, celebrados com organismos internacionais. Cabe destacar que a SNJ já tinha experiência no uso deste instrumento, inclusive para atividades de desenvolvimento do Portal da Juventude; e que a própria SNAS havia utilizado o instrumento para o desenvolvimento do Participa.br. Além da capacidade administrativa no uso do instrumento, havia histórico recente de mobilização e engajamento de consultores e da comunidade Noosfero para concorrer e disputar vagas de editais deste tipo. A própria comunidade do software já conhecia, portanto, o instrumento.

Como já foi apresentado no capítulo anterior, esse tipo de acordo de cooperação técnica internacional entre entidades públicas federais (de administração direta ou indireta) e organismos internacionais (como UNESCO, PNUD, OEI) tem o objetivo de fortalecer políticas públicas do Governo Federal, facilitando a mobilização de pessoal especializado por parte dos órgãos públicos. O Tribunal de Contas da União (TCU) já debateu este instrumento, como nos mostra o voto do Ministro Relator José Jorge, no Acórdão TCU n ${ }^{\circ}$ 1.339/2009 Plenário:

(...) os propósitos dos projetos de cooperação técnica estão restritos às hipóteses nas quais haja transferência de conhecimentos ou exista assessoria técnica, a qual, por seu turno, deve compreender atividades de treinamento, consultoria, bem como a aquisição de bens e contratação de serviços, desde que estes estejam vinculados ao desenvolvimento das ações contidas no acordo básico de cooperação e que não possam ser executadas pelo próprio órgão pertencente à administração pública federal. (TCU, 2009)

Em resumo, como indicamos previamente no Capítulo 4, os acordos básicos de cooperação técnica internacional prestada ao Brasil não podem ser instrumentos para viabilizar a contratação de serviços que possam ser executados por seus próprios servidores e devem servir para a transferência de conhecimento por parte do organismo internacional. Também não devem ser utilizados para casos que tratem de temas e práticas de domínio 
público, demandados rotineiramente pela Administração e disponíveis no mercado (para estes casos, o instrumento deve ser o de contração de bens e serviços de natureza comum). Esse instrumento foi utilizado no desenvolvimento do Participa.br e pelas Conferências Nacionais de Educação e na de Transparência e Controle Social.

No caso específico da $3^{\text {a }}$ Conferência Nacional de Juventude, já havia acordo em vigência e com orçamento previsto, possibilitando a rápida mobilização de consultores externos, o que de fato foi feito para responder à SNJ, seja porque essa secretaria não tem equipe própria especializada, seja por se identificarem aspectos de inovação metodológica e tecnológica cuja solução se diferenciava do que já existia ou vinha sendo oferecido pelo Serpro através do Portal da Juventude - exigindo novos desenvolvimentos. No entanto, buscou-se um arranjo híbrido de modo a envolver o Serpro e estimular sua interação no processo, se apropriando do que fosse produzido e viabilizando a manutenção posterior.

No que se refere à equipe de gestão da $\mathrm{SNJ}$ - dos servidores e gestores dedicados a acompanhar o processo de desenvolvimento da tecnologia - não havia ninguém especializado e que pudesse realizar a análise técnica do desenvolvimento realizado pelos consultores. Em outras palavras, o produto específico (artefato) resultado da ação dos consultores poderia ser avaliado de duas maneiras: 1) de acordo com efeitos do produto entregue em relação ao que fora demandado - avaliação feita pela própria SNJ, com apoio da DITEC e também da SNAS; 2) por meio de uma avaliação técnica (possível ou mesmo necessária), sobre o código produzido. Esse segundo tipo bastante específico de gestão técnica foi realizado, segundo as entrevistas, por Leandro Nunes do Serpro e mesmo pelo consultor Caio Sacramento, ambos pela experiência acumulada no desenvolvimento em Noosfero. O Serpro, no entanto, não tinha esse papel instituído no arranjo. O debate específico sobre essa questão será aprofundado no Capítulo 6, ressaltando ainda que há certa dificuldade em enquadrar estas atividades apenas como uma atividade de gestão do processo de desenvolvimento da tecnologia.

\subsubsection{Recursos Financeiros e Físicos}

Essa subcategoria diz respeito ao orçamento, à estrutura física e a outros suprimentos disponíveis para a execução da iniciativa de utilização de TICs em participação social. As entrevistas destacaram as dificuldades específicas da iniciativa da $3^{\text {a }}$ Conferência Nacional de 
Juventude, que buscava ser o primeiro caso que possibilitaria a eleição de delegados e de propostas por meio de tecnologia digital. Além disso, o prazo curto para esse desenvolvimento foi apontado por vários entrevistados como um dos fatores que geraram dificuldade ao longo do processo.

Em especial dois recursos mobilizados são apontados como decisivos para enfrentar tais dificuldades. Em primeiro lugar, a existência de acordo de cooperação internacional em vigência, possibilitando a contratação de consultores externos. Nesse sentido, Carla Bezerra explica em sua entrevista (2017) que o fato de a maior parte dos recursos previstos para esse tipo de consultoria estar designado para uso da SNJ fez com que a gestão deste acordo fosse realizado diretamente pela Secretaria Nacional de Juventude, dando ainda mais autonomia e celeridade para seu uso.

Além desse acordo de cooperação em vigência, a existência de contrato entre o Serpro e a Presidência da República para o Noosfero/Participa.br se configurava como uma oportunidade de mobilizar esse recurso de maneira rápida. $\mathrm{O}$ contrato em vigor estipulava as atividades de desenvolvimento e a manutenção do software como objeto e quantidade determinada de pontos de função, dando autonomia para a definição de quais tarefas seriam executadas. A institucionalidade da $3^{\text {a }}$ Conferência Nacional de Juventude (que será apresentada a seguir) e a articulação política construída pela SNJ viabilizaram o compromisso de que uma parte destes pontos de função seriam destinados ao projeto da Conferência, ou seja, que o Serpro ofereceria suporte e executaria parte do desenvolvimento previsto.

Estes recursos têm grande relação com a categoria de Capacidades Estatais Administrativas, pois ao mesmo tempo se constituíram como recursos financeiros existentes e possíveis de serem mobilizados e como instrumentos administrativos viáveis para os desafios específicos da iniciativa (prazo e necessidade de mobilizar recursos humanos especializados ou com experiência em Noosfero).

\subsubsection{Tecnologia}

Esta subcategoria diz respeito aos aspectos tecnológicos, e em especial, ao tipo de tecnologia utilizada. Como foi apresentado anteriormente, a $3^{\text {a }}$ Conferência Nacional de Juventude utilizou o Portal da Juventude que é desenvolvido em software Noosfero. Mais precisamente, o Portal está dentro do Participa.br, ou seja, quando se desenvolve qualquer 
funcionalidade no Portal da Juventude se produz, na verdade, funcionalidades do Participa.br. Tratava-se de um recurso já mobilizado pela SNJ anteriormente, ou seja, já constituía uma capacidade de tecnologia existente, com equipe do Serpro dedicada por meio de contrato em vigência com a Presidência da República. A hospedagem e a manutenção da tecnologia estavam asseguradas por este contrato, sob supervisão tanto da SNJ, quanto da Ditec. Além disso, o contrato possibilitava a alocação de Pontos de Função para o desenvolvimento de novas funcionalidades, que também poderiam beneficiar o Portal da Juventude de duas maneiras: 1. quando desenvolvidas para o Participa.br, uma vez que o Portal da Juventude estava baseado ali; 2. quando desenvolvidas diretamente a pedido da SNJ.

Trata-se, portanto, de um arranjo flexível tanto para momentos em que a SNJ tivesse projetos ou demandas de novo desenvolvimento, quanto para os momentos em que não houvesse nenhum projeto de desenvolvimento de software na SNJ, mas em que houvesse aperfeiçoamento e desenvolvimento contínuos do Participa.br.

Além de utilizar o Portal como backend, foi desenvolvido um frontend em Ionic/AngularJS de modo a produzir um aplicativo específico para celulares/smartphones. Este aplicativo se conectava ao Portal, ou seja, ambos conformavam um artefato único (do ponto de vista desta pesquisa). Essa análise se refere ao fato de que o artefato era entendido como uma coisa só tanto por usuários, quanto pelos gestores à frente da SNJ. Era o artefato, único, que deveria entregar determinadas funcionalidades e uma dinâmica de funcionamento alinhada à metodologia da Conferência, por exemplo. A separação em backend e frontend diz mais respeito ao processo de trabalho na dimensão da engenharia de software.

Parte significativa da equipe de desenvolvimento foi composta por consultores externos, que atuaram conjuntamente a gestores da SNJ, SNAS, DITEC e, especialmente, do Serpro. Em termos mais amplos do que se compreende por time de desenvolvimento (concepção, especificação, programação, revisão e aprovação), estas foram as organizações participantes. A partir da escolha do uso em Noosfero e da percepção de que novas funcionalidades e um aplicativo móvel eram desejados, a SNJ mobilizou recursos de tecnologia em três frentes: 1. por meio de contrato com o Serpro; 2. via órgãos internos à Secretaria Geral da Presidência da República; 3. por intermédio de consultores externos. Do ponto de vista da tecnologia, vale destacar que essa mobilização buscou constituir capacidade estatal no desenvolvimento específico desta tecnologia, o que foi efetivamente alcançado. Dos 
oito membros dedicados mais diretamente ao desenvolvimento, apenas um não tinha experiência prévia em Noosfero, como as entrevistas revelam.

Dessa maneira, Serpro e consultores atuaram conjuntamente. O código produzido pelos consultores era revisado pela equipe do Serpro, responsável por aceitar estes códigos e atualizar a versão do Noosfero Gov (Participa.Br). Como a atualização destas versões poderia impactar todos os serviços e plataformas que utilizavam o Participa.Br, este trabalho de revisão respondia ao interesse comercial do Serpro, mesmo que não fosse uma atividade remunerada diretamente. Tal questão será aprofundada no Capítulo 6; mas aqui cabe destacar que o time de consultores não teve acesso a um ambiente de homologação ${ }^{41}$, pois o Serpro, que é o responsável pela hospedagem do software, ainda impõe limitações para o acesso de indivíduos e máquinas não pertencentes ao seu quadro funcional. Essa limitação dificultou a rotina de testes (como indicaram as entrevistas de Sacramento, 2017; Poppi, 2016, 2017; e Hugo Melo, 2017) ao longo da produção do código, concentrando ainda mais a responsabilidade da revisão, do teste e da aprovação no próprio Serpro. Tal posicionamento deve ser debatido à luz da nova Estratégia de Governança Digital assumida pela Administração Pública Federal, pois a criação de protocolos de acesso a ambientes de desenvolvimento e de homologação é necessária para viabilizar arranjos de desenvolvimento híbrido nos quais equipes e indivíduos ligados a distintas organizações e órgãos participam, como no caso estudado, ou mesmo para viabilizar a contribuição de membros da comunidade de um software e de cidadãos de maneira geral. Em outras palavras, constitui capacidade estatal necessária para a efetiva mobilização de contribuições externas (de terceiros) e para a coprodução.

\subsubsection{Gestão do Processo Participativo}

Essa subcategoria faz referência a questões como a prestação de contas do processo à sociedade, em especial ao feedback dado aos participantes, demonstrando os resultados de sua participação e do processo como um todo. Ela também diz respeito à moderação e à mediação realizadas durante o processo, bem como sobre a gestão em si da iniciativa, o que pode abarcar uma série de outros elementos mais gerais.

\footnotetext{
$\overline{41} \quad$ O ambiente de homologação é o ambiente de teste; o desenvolvedor produzirá o software no ambiente de desenvolvimento e então irá publicá-lo no ambiente de homologação.
} 
Como já foi apresentado no Capítulo 4, a gestão do processo foi liderada pela Secretaria Nacional de Juventude, que mobilizou ainda a SNAS, a DITEC, o Serpro e um time de consultores externos. A SNJ liderou a gestão completa do processo participativo, incluindo a articulação e a liderança política com o Conselho Nacional de Juventude e com Secretarias e Conselhos de Juventude de todo o país. Especificamente na etapa digital e no desenvolvimento da tecnologia utilizada pela Conferência (objeto desta investigação), a SNJ liderava o processo de especificação política para guiar o desenvolvimento (quais funcionalidades deveriam ser criadas para atender a quais demandas); a comunicação e a orientação geral sobre o processo (será especificado na subcategoria de Comunicação); e as avaliações sobre as entregas e os produtos do time de consultores, que eram realizadas por meio de relatórios descritivos e também do teste de avaliação da tecnologia. Essa questão específica da avaliação técnica da produção de código, já abordada no quesito de Recursos Humanos (5.1.1) e dificilmente classificada sob uma única subcategoria, será ainda debatida no item 5.5.

Por fim, a metodologia criada buscou minimizar as necessidades de mediação e moderação, distribuindo as responsabilidades de moderação para os usuários (que poderiam denunciar conteúdos impróprios segundo termos de uso publicados com destaque). Já a mediação era feita pelos próprios participantes, estimulados a comentar e contribuir nas propostas dos demais (cada comentário realizado na proposta de outra pessoa rendia pontos para a seleção de delegados). A partir desses meios, o processo tinha como objetivos a seleção de propostas e de delegados que poderiam participar da etapa nacional da Conferência objetivos que foram comunicados na tecnologia e de maneira intensa pela equipe de comunicação da SNJ. Ao final, todas as propostas selecionadas foram publicadas e os delegados digitais eleitos receberam notificações diretas nos e-mails cadastrados no aplicativo. O desenvolvimento tecnológico buscou responder a essas demandas de mediação, moderação e feedback apresentadas pela SNJ, potencializando ao máximo os resultados e reduzindo a necessidade de recursos humanos para estas tarefas.

\subsection{CAPACIDADES ADMINISTRATIVAS}

A dimensão administrativa se refere a funções organizacionais e administrativas da Administração Pública, considerando as exigências, limitações e condições de atuação de 
acordo com a realidade do poder público. No Conceito de Capacidades de Governo Relacionadas à Utilização de TICs em Processos de Participação Social (CGTPS, STEFANI, op. cit.), duas subcategorias foram destacadas: TI na Administração Pública e Lócus do Tema no Governo.

\subsubsection{Lócus do Tema no Governo}

O lócus administrativo onde se desenvolve a iniciativa de utilização de TICs em participação social se mostrou relevante no caso estudado. A facilidade de mobilização dos recursos da Secretaria Nacional de Articulação Social que auxiliaram no planejamento do processo de desenvolvimento e contratação decorre, em alguma medida, do fato de ambas as Secretarias estarem localizadas na Secretaria Geral da Presidência da República. De maneira análoga, a mobilização da Diretoria de Tecnologia (DITEC), apoiando a gestão do contrato com o Serpro, é influenciada pela mesma questão. A SGPR estava envolvida em diversos processos participativos e, desde o lançamento do Participa.br, vinha aumentando sua interação com outros órgãos e ministérios interessados nesse tipo de iniciativa. Assim, constituía um lócus propício para a realização de consultas e processos participativos que utilizassem tecnologias, bem como para o desenvolvimento e aperfeiçoamento tecnológico com essa finalidade política.

Inicialmente, imaginou-se inclusive contar com o benefício de utilizar boa parte dos pontos de função do contrato existente entre a Presidência e o Serpro. Essa previsão inicial se frustrou quando a Presidência passou a priorizar outro projeto utilizando Noosfero, o Dialoga Brasil, como já apontamos no capítulo anterior, mas é notório que o Serpro pôde executar alguns dos pontos de função previstos e, como vimos na entrevista de Leandro Nunes (2017), executar ou tolerar que seu servidor executasse algumas ações de revisão e assessoramento.

\subsubsection{TI na Administração Pública}

A capacidade administrativa que apareceu mais frequentemente durante a análise foi a questão da própria tecnologia enquanto área de governo e a relação dos departamentos de TI com a ascensão de tecnologias inovadoras em processos de participação social conduzidos pelo Governo. 
Essa subcategoria, ao lado da de Tecnologia, foi a mais recorrente na análise das entrevistas e, haja vista a constituição do objeto desta pesquisa, tem grande relevância. Por isso, buscou-se uma compreensão um pouco mais ampla sobre a temática de desenvolvimento e contratação de software pela Administração Pública Federal, por meio do exame da Instrução Normativa $N^{\circ} 4$ de 11 de Setembro de 2014 (STI, 2014) ${ }^{42}$; do Guia de Boas Práticas em Contratação de Soluções de Tecnologia da Informação (STI, 2017a) ${ }^{43}$; do documento de "Boas práticas, vedações e orientações para contratação de software e de serviços de desenvolvimento e manutenção de sistemas (Fábrica de Software)"44 (STI, 2017b); e do Relatório da Auditoria Operacional realizada mediante autorização do Tribunal exarada no Acórdão no 505/2015 (TCU, 2015) ${ }^{45}$.

O documento de "Boas práticas, vedações e orientações para contratação de software e de serviços de desenvolvimento e manutenção de sistemas (Fábrica de Software)" da Secretaria de Tecnologia da Informação, STI (2017) resume algumas das diretrizes gerais para a contratação de desenvolvimento de software pela APF:

B. Contratações de serviços de desenvolvimento e manutenção de sistemas:

2. Antes de decidir pela contratação de serviço de desenvolvimento de software ou pela abertura de projetos de desenvolvimento de software, a Equipe de Planejamento da Contratação ou a Equipe de Gestão de Projetos do órgão deve realizar Estudo Técnico Preliminar, nos termos do disposto no art. 12 da Instrução Normativa SLTI/MP n ${ }^{\circ}$ 4, de 11 de setembro de 2014, e executar as seguintes atividades:

2.1. Analisar a existência e a viabilidade de adoção de software que atenda às necessidades da área requisitante no Portal do Software Público Brasileiro (https://softwarepublico.gov.br/);

2.2. Analisar a existência e a viabilidade de adoção de software livre que atenda às necessidades da área requisitante;

\footnotetext{
$\overline{42}$ Dispõe sobre o processo de contratação de Soluções de Tecnologia da Informação pelos órgãos integrantes do Sistema de Administração de Recursos de Tecnologia da Informação e Informática (SISP) do Poder Executivo Federal. Esta Instrução Normativa entrará em vigor em 2 de janeiro de 2015, quando restará revogada a Instrução Normativa SLTI/MP n. 4, de 19 de maio de 2010, e suas alterações. Disponível em: $<$ https://www.governoeletronico.gov.br/documentos-e-arquivos/1\%20-\%20IN\%204\%20\%2011-9-14.pdf $>$. Acesso em: 15/02/18.

${ }^{43} \mathrm{O}$ Guia reúne um conjunto de boas práticas para contratações de Soluções de Tecnologia da Informação (TI) pela Administração Pública Federal e deve ser utilizado pelos mais de 200 órgãos integrantes do Sistema de Administração dos Recursos de Tecnologia da Informação (SISP). Disponível em: $<$ http://www.planejamento.gov.br/noticias/lancada-nova-versao-do-guia-de-boas-praticas-em-contratacao-desolucoes-de-ti/guia de boas praticas v08.pdf/view $>$. Acesso em: 15/02/18.

${ }_{44}$ Este documento de Boas práticas, Orientações e Vedações tem força normativa legal, estando vinculado à Portaria MP/STI n ${ }^{\circ}$ 20, de 14 de junho de 2016, na forma de anexo, tendo sido assinado, em sua última versão, pelo Secretário de Tecnologia da Informação do Ministério do Planejamento, Desenvolvimento e Gestão em 24/03/2017 e publicado em 28/03/2017. Disponível em: $<$ https://www.governoeletronico.gov.br/documentos-earquivos/Contratacao $\% 20 \mathrm{de} \% 20$ Softwares $\% 20 \mathrm{e} \% 20 \mathrm{de} \% 20$ Servicos $\% 20 \mathrm{de} \% 20$ Desenvolvimento $\% 20 \mathrm{e}$ \%20Manutencao $\% 20 \mathrm{de} \% 20$ Sistemas $\% 20$-Fabrica $\% 20 \mathrm{de} \% 20$ Software.pdf $>$. Acesso em: 15/02/18.

${ }^{45}$ Auditoria De Natureza Operacional. Avaliação da eficácia e eficiência do Modelo de Contratação de Desenvolvimento e Manutenção de Sistemas Informatizados Adotado pelas Organizações Componentes da Administração Pública Federal (Apf), Em especial quando utilizados Métodos Ágeis de Desenvolvimento, visando a apresentar entendimentos quanto aos riscos e métricas utilizados.
} 
2.3. Analisar projetos similares realizados por outros órgãos ou entidades da Administração Pública;

2.4. Consultar a Secretaria de Tecnologia da Informação sobre contratações conjuntas ou planejamento conjunto para desenvolvimento de solução que possa atender a necessidade; $\mathrm{e}$

2.5. Analisar a viabilidade de contratação de software proprietário.

2.6. Dentre as possibilidades elencadas nos itens acima, devem ser analisados os modelos de negócio para a escolha do que mais se adequa ao atendimento das necessidades de negócio, necessidades técnicas e a viabilidade econômica, quais sejam:

2.6.1. Software como Serviço (SaaS);

2.6.2 Aluguel ou subscrição; ou

2.6.3. Licença de uso.

3. Recomenda-se que as contratações de serviço de desenvolvimento de software sejam realizadas por produto, por linguagem ou por área de negócio.

3.1 Em contratações por produto, recomenda-se que elas sejam realizadas com o escopo definido de cada um dos produtos a serem desenvolvidos. Tal recomendação visa minimizar o conflito de interesses criado pela contratação com escopo aberto.

3.2. Caso não seja possível contratar serviço de desenvolvimento de software por produto, é recomendada a contratação do serviço com escopo aberto, desde que um Estudo Técnico Preliminar com a definição de escopo anteceda a abertura de cada projeto de desenvolvimento de software.

3.3 Nos casos elencados nos itens 2.1 e 2.2, deve-se realizar a estimativa de todas as potenciais demandas para compor o escopo, que servirá como base para a contratação ou ordem de serviço. (STI, 2017b, s.p.)

O documento deixa claro o estímulo para a adoção de softwares já desenvolvidos (com maior maturidade e estabilidade) em vez do desenvolvimento de novas soluções. Também dá preferência para a adoção de softwares públicos ou softwares livres em detrimento de softwares proprietários e, para os casos de novo desenvolvimento, para que seja feito com escopo bem definido, por produto, facilitando a especificação prévia à contratação e a avaliação da entrega.

Mesmo assim, a fiscalização de 2015 realizada pelo Tribunal de Contas da União (TCU, 2015) e publicada no Relatório da Auditoria Operacional realizada mediante autorização do Tribunal exarada no Acórdão no 505/2015 aponta que "menos de 12\% das soluções de aplicativos de software implantadas nos últimos três anos nas respectivas organizações [cujos gestores foram entrevistados] correspondem a soluções prontas de mercado". Outro número emblemático é de que o percentual relativo a software público, livre ou gratuito não chega a $6 \%$. O Relatório da Auditoria Operacional realizada mediante autorização do Tribunal exarada no Acórdão no 505/2015 - TCU - Plenário continua:

[...] 82,4\% das soluções de software providas nos últimos três anos nas instituições acima elencadas correspondem a software desenvolvido. Desses, $50,3 \%$ se referem a desenvolvimento contratado e $32,1 \%$ a desenvolvimento interno. Já o provimento por meio de soluções prontas deu-se em 17,6\% dos casos, sendo $11,9 \%$ correspondentes a soluções de mercado e apenas $5,7 \%$ relativos a software público, livre ou gratuito. (TCU, 2015, s.p..) 
As informações prestadas pelos gestores durante a investigação ainda apontam que “93\% das contratações é de serviço com escopo amplo, ficando apenas 7\% absorvidas por contratos por projeto fechado, e nenhuma contratação de desenvolvimento conjunto [com outros órgãos]" (TCU, 2015)..

Em síntese, as principais recomendações indicam a adesão a soluções prontas e a busca por tais soluções antes de se iniciar o desenvolvimento de uma nova tecnologia. Quando o objetivo for a adesão a uma solução existente, que seja priorizada a adesão a softwares livres. E quando for identificada a necessidade de desenvolvimento, que seja com escopo fechado, delimitando bem os objetivos e entregas.

Justamente por serem recomendações seguidas em uma minoria dos casos, chama a atenção o fato de que a iniciativa de desenvolvimento da tecnologia utilizada pela $3^{\text {a }}$ Conferência Nacional de Juventude seguiram essas três recomendações principais: aderiram ao Noosfero Gov, através do Participa.Br, cumprindo tanto a recomendação de priorizar soluções existentes, quanto a premissa do software livre; e para o desenvolvimento das funcionalidades necessárias que ainda não existiam, optou-se por um escopo bastante delimitado, com entregas bem claras para atender as demandas da Conferência Nacional, que chegaram inclusive a ter algumas funcionalidades descritas em Resolução publicada pela Comissão Nacional Organizadora da Conferência.

Como já foi dito, a SNJ já utilizava Noosfero em seu Portal da Juventude e já detinha uma relação de parceria com o Serpro e com a SNAS (desde a migração do Portal), constituindo uma espécie de arranjo em torno desse software livre. Ainda que sem equipe especializada no desenvolvimento, a existência do Portal da Juventude, a realização do processo de migração e a incorporação dessa tecnologia pela SNJ em diferentes âmbitos também acaba por constituir capacidade a ser destacada.

Do ponto de vista da TI pública, é especialmente importante reforçar o fato de o Serpro adotar o Noosfero como software de uso corporativo e ter equipe altamente especializada, contribuindo como fator em prol da sustentabilidade e da melhoria contínua do software, atraindo a adesão de outras organizações.Essa capacidade do Serpro se traduzia, por exemplo, em contrato com a Presidência da República em vigência à época do projeto e com a hospedagem realizada pelo Serpro, como um serviço prestado. Ela também se materializa pelas duas principais atividades realizadas pelo Serpro durante a iniciativa: 1) no desenvolvimento de código para atender algumas das demandas de desenvolvimento, em 
especial na API do Noosfero; e 2) na revisão e no caráter de assessoramento ao time de consultores, orientando sobre decisões de desenvolvimento e avaliando eventualmente códigos produzidos e dúvidas levantadas pela equipe. Se aquela primeira atividade deixa claro de que maneira as capacidades do Serpro foram mobilizadas pela SNJ através do contrato firmado entre as partes, a segunda atividade destaca um dos pontos que serão debatidos no Capítulo 6: o fato de que os contratos com empresas públicas e privadas de software que via de regra utilizam o instrumento dos Pontos de Função para gestão e controle não fomentam, nem remuneram atividades dos desenvolvedores nas comunidades do software utilizado. Seja em um modelo híbrido, como foi o caso da $3^{\text {a }}$ Conferência Nacional de Juventude, na qual a equipe do Serpro colaborou com a equipe de consultores (sendo que ambas atuaram dentro da iniciativa), seja de modo a estimular que os desenvolvedores mantenham relevância e centralidade, interagindo com outros desenvolvedores e favorecendo a apropriação de melhorias e códigos construídos por outras organizações.

\subsection{CAPACIDAdes Políticas}

As capacidades políticas (CGPTPS) se referem à negociação, à mediação e ao processamento das demandas entre os diversos atores e interesses envolvidos em determinada ação estatal ou política. Anita Stefani (2015) aponta três subcategorias: Participação como Orientação de Governo; Liderança e Condução Política; e Comunicação/Divulgação.

\subsubsection{Participação como Método de Governo}

Esta subcategoria faz referência ao valor dado à participação social e ao convencimento sobre essa questão pelas equipes e pela burocracia, além de aludir a certa cultura política a respeito da importância da temática na agenda e nas ações do governo.

No caso estudado algumas questões chamam atenção. Em primeiro plano, as diretrizes e decisões políticas sobre os rumos da $3^{\text {a }}$ Conferência eram propostas pela Secretaria Nacional de Juventude em boa parte dos casos, mas quase sempre dependiam de deliberação e aprovação da Comissão Nacional Organizadora, composta pela SNJ e também pelo Conselho Nacional de Juventude. Em outras palavras, decisões importantes eram tomadas de maneira compartilhada entre gestão e sociedade. O processo de decisão era, institucionalmente, 
participativo. Essa participação fica evidenciada não apenas pelas Resoluções aprovadas, mas também pela participação direta de membros indicados pelo Conselho em atividades de mobilização e articulação, como se evidenciou na entrevista com Tamara Terso (2017).

Além da equipe da SNJ ter quadros oriundos de movimentos de juventude, do próprio Conselho Nacional ou ainda com participação nas duas Conferências Nacionais anteriores, a mobilização de consultores externos também incorporou a atuação social e o ativismo como critérios a serem observados. Isso foi possível graças à flexibilidade do instrumento de contratação de consultores, que permite a definição de critérios diversos de experiência no edital de chamamento, e quase sempre exige a realização de uma etapa de entrevistas dentro da seleção, na qual atributos deste tipo podem ser observados.

$\mathrm{O}$ uso desse instrumento de mobilização de equipe se revelou positivo para o engajamento de pessoas especializadas e com experiências prévias que se revertessem em benefício para a iniciativa. Da equipe dedicada ao desenvolvimento tecnológico, por exemplo, todos os entrevistados relataram sua atuação em comunidades de software livre e em outros projetos utilizando Noosfero. Esse fato se mostrou positivo para otimizar as atividades, uma vez que já havia conhecimento entre alguns consultores e servidores da SNAS e do Serpro, por todos fazerem parte da comunidade Noosfero. As interações ficaram mais orgânicas e diretas e a necessidade de apropriação sobre a tecnologia, sobre o estado atual do Noosfero e sobre o desenvolvimento proposta também foram beneficiados.

\subsubsection{Liderança e Condução Política}

A habilidade política do líder e de sua equipe na condução de projetos e políticas públicas é uma subcategoria importante e, no caso estudado, foi ressaltada por uma série de fatores. Desde o desenho institucional do caso, que instituía a decisão e a deliberação compartilhada com o Conselho Nacional de Juventude, implicando permanentes estratégia e ação políticas de negociação e debate. Como fica claro nas entrevistas com Tamara Terso (2017) e Gabriel Medina (2017), anteriormente apresentadas na subcategoria de 5.3.1 Participação como Método de Governo, até mesmo as regras de participação e de premiação eram deliberados com o Conselho, assim como os critérios de escolha dos delegados e outras definições mais estratégicas. 
O caráter inovador da metodologia e da tecnologia, assim como a ênfase até então inédita no uso de ferramentas digitais em uma Conferência Nacional geraram debates e resistência por parte de alguns atores, implicando a necessidade de que a SNJ atuasse em defesa da proposta. Além disso, a própria negociação para que a SNJ fosse mantida enquanto Secretaria Nacional quando da reorganização administrativa demandou a ação e a liderança política. Foi mais um caso que demandou articulação conjunta com o Conselho Nacional e demais conselhos e órgãos de juventude do país.

O próprio envolvimento do Serpro foi objeto de intensa negociação política. A princípio obteve-se aprovação para que parte dos pontos de função do contrato da Presidência da República fossem utilizados para a $3^{\text {a }}$ Conferência Nacional de Juventude e, a partir do crescente protagonismo do Dialoga Brasil, negociou-se e consegui-se a permanência de atendimento e cobertura parciais.

Outro caso no qual a liderança política se mostrou decisiva para a efetiva mobilização de recursos e constituição de capacidades foi na comunicação. Assim como na TI, a impossibilidade de mobilizar recursos da Presidência da República (destinados quase que exclusivamente para o Dialoga Brasil) fez com que a liderança política da SNJ negociasse politicamente recursos mínimos, ao mesmo tempo em que buscou articulação e colaboração com grupos e organizações da sociedade, estabelecendo parcerias e construindo redes de apoio e de ação coletiva para conseguir maior repercussão e audiência. No entanto, vale ressaltar como os próprios atores entrevistados apontam a fragilidade destas soluções para contrapor aos efeitos e prejuízos percebidos da falta de recursos próprios que se constituíssem em capacidades para a iniciativa. Não se trata, pois, de uma fragilidade por serem recursos mobilizados a partir da sociedade, mas sobretudo por terem sido mobilizados de maneira emergencial, após uma mudança de cenário e de uma frustração na mobilização de recursos próprios, sem devidos planejamento e incentivos.

\subsubsection{Comunicação}

A comunicação da iniciativa sofreu especialmente com a frustração de que haveria empresa contratada especificamente para dar suporte à Conferência Nacional, o que não se realizou. Dessa forma, foi organizada uma equipe interna mínima, com poucas pessoas (priorizando dentre os poucos cargos de livre nomeação existentes) e a principal diretriz de 
trabalho foi buscar parceria e colaboração com comunicadores e coletivos de comunicação dentro do campo da juventude.

O protagonismo concedido ao projeto Dialoga Brasil também criou uma dificuldade, nessa subcategoria, para que a SNJ fosse atendida pela assessoria de imprensa e pela área de comunicação da Secretaria Geral da Presidência da República. O processo caminhou com baixa capacidade própria (da SNJ ou da PR), sem contratação específica e baseado na articulação política com grupos da sociedade.

\subsection{CAPACIDADES INSTITUCIONAIS}

A dimensão institucional de capacidades estatais na utilização de TICs em processos participativos (STEFANI, 2015) diz respeito ao âmbito legal e formal que dá suporte às iniciativas. Duas subcategorias a compõem: Institucionalidade do Processo e Pluralidade Institucional do Governo.

\subsubsection{Institucionalidade do Processo}

A $3^{\text {a }}$ Conferência Nacional de Juventude teve sua realização estabelecida por Decreto publicado no Diário Oficial da União, espécie de selo oficial de reconhecimento do processo. Além disso, pesa a favor da institucionalidade do processo a conjuntura de esta ser a terceira conferência do tema, seguindo calendário estabelecido pela conferência anterior e compactuando política, metodológica e tecnologicamente com as organizações pertencentes do Conselho Nacional de Juventude, como destacam Tamara Terso (2017) e Gabriel Medina (2017) em suas entrevistas.

A própria característica de ser uma Conferência Nacional, ou seja, a principal ação do Estado para a promoção da participação social, dá peso institucional à iniciativa, que é liderada formalmente pela Comissão Organizadora Nacional, constituída pela SNJ e pelo Conselho Nacional, e que delibera suas decisões através de resoluções públicas. Tais elementos foram destacados a partir das entrevistas e da coleta de documentos; e o papel do Conselho Nacional, por vezes ampliando o espaço de atuação e de interesses da própria SNJ 
frente ao restante do governo, foi ressaltado no episódio em que mudanças ministeriais ${ }^{46}$ ameaçaram a manutenção da SNJ como uma Secretaria, com o status que ela detinha.

Tal proposta, que fazia parte de uma iniciativa de reorganização de secretarias e órgãos, foi duramante combatida pelo Conselho Nacional de Juventude e por uma série de movimentos, conselhos e conselheiros, como uma ameaça à política de juventude. Gabriel Medina (2017) e Carla Bezerra (2017) relatam tais questões do contexto político como dificuldades enfrentadas pela Conferência Nacional e que tiveram efeito sobre a iniciativa, configurando ameaça à Conferência a despeito de sua institucionalidade. Gabriel descreve, por exemplo, a perda de servidores e de equipe, enfraquecendo o processo; mas ressalta, por outro lado, que a atuação do Conselho e a própria mobilização construída em torno da $3^{\text {a }}$ Conferência Nacional de Juventude acabaram por constituir barreiras para a extinção da SNJ. De todo modo, no caso investigado, mesmo o reconhecimento oficial da iniciativa e a institucionalização existente em torno da SNJ e do Conselho Nacional se viram ameaçados por um processo de reorganização ministerial. É difícil aventar, no entanto, qualquer suposição da real ameaça e dos efeitos, já que tais medidas não se confirmaram. Mas as entrevistas revelam um temor real de que o impacto poderia ameaçar a conclusão e a realização do processo.

Por fim, o uso de TICs pela $3^{\text {a }}$. Conferência Nacional de Juventude não estava garantido pelo Decreto Presidencial que convocou a Conferência, mas estava garantido pelo Regimento publicado através de Portaria no DOU em 18 de junho de 2015. Também foi objeto de algumas Resoluções da CON, reforçando o reconhecimento sobre o uso de TICs e sobre o desenvolvimento da tecnologia para a Conferência.

\subsubsection{Pluralidade Institucional do Governo}

Esta subcategoria faz referência ao fato de que, para muitos casos e políticas, os distintos órgãos da Administração Pública Federal têm visões, preferências e interesses diversos. Em outras palavras, há uma pluralidade institucional dos atores governamentais e uma interação multidirecional.

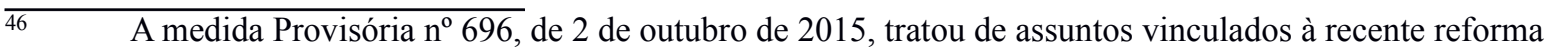
ministerial e inicialmente transferiu funções da SNJ ao então criado Ministério das Mulheres, da Igualdade Racial e dos Direitos Humanos, sem prever uma estrutura específica de Secretaria Nacional e gerando temor de que a partir de então o tema seria conduzido por uma Assessoria ou estrutura administrativa de menor porte e status administrativo e político.
} 
No caso estudado, não foi possível constatar uma visão estratégica, com maior mobilização de recursos e incentivos, por parte dos diferentes órgãos da Administração Pública (notadamente da SGPR e do Serpro) sobre o Noosfero. Ainda que o software tenha sido utilizado para uma série de iniciativas relevantes (Participa.br, Dialoga Brasil e Portal do Software Público), as entrevistas apontam que a decisão inicial no uso do software contou com certo ativismo e com um tipo de empreendedorismo político por parte de gestores e agentes políticos da Administração Pública Federal, mais do que com uma ação coordenada ou uma estratégia de adoção e de desenvolvimento desse software. Os/as entrevistados/as também não percebem uma ação coordenada do Estado para deter influência sobre o Noosfero ou fomentar a atuação de outros participantes da comunidade, de modo que o Estado se beneficie de melhorias produzidas pela comunidade em suas própria iniciativa (do Estado). $\mathrm{O}$ caso do Serpro é exemplar pois, como foi evidenciado na entrevista com Leandro Nunes (2017) supracitada, este software ainda não se encontrava nem mesmo homologado.

No entanto, é fato que havia o uso do Noosfero por outros órgãos. O próprio caso do Dialoga Brasil gerou influências sobre o processo, concentrando recursos e capacidades da Presidência da República pelo menos no que se refere à Comunicação e à TI, reduzindo os recursos disponíveis que a SNJ poderia tentar mobilizar. Além disso, o histórico de desenvolvimento pela SNAS e pelo Serpro trazia, ao mesmo tempo, potencial colaboração e presença de atores com interesses, visões e pontos de vista próprios sobre o desenvolvimento do software. Dessa maneira, a interação permanente entre SNJ, SNAS, Serpro e o time de consultores para o debate sobre as demandas, para a especificação de soluções e mesmo para decisões mais técnicas conformou um espaço plural, com a presença efetiva de organizações distintas, através de seus atores.

Do ponto de vista da pluralidade institucional cabe observar que o Serpro detinha uma espécie de prevalência sobre o software, pelo fato de hospedá-lo e deter uma equipe especializada e atuante há mais tempo na comunidade do Noosfero Gov. De maneira adicional, os recursos humanos especializados em engenharia de software e programação que foram mobilizados pela SNJ eram de consultores externos, com dedicação temporária e restrita ao projeto. Tal prevalência é uma questão que não pôde ser esgotada na presente investigação. No item 5.5 essa questão será discutida de forma a evidenciar a importância de servidores/ gestores especializados para atuar neste âmbito. 


\subsection{ReFleXões SOBRE O CONCEITO DE CAPACIDADES DE GOVERNO RElACIONADAS À UtilizaÇÃo de TICs EM PROCESSOS DE PARTICIPAÇÃo Social (CGTPS)}

O uso do conceito de Capacidades de Governo Relacionadas à Utilização de TICs em Processos de Participação Social (CGTPS) desenvolvido por Stefani (2015) para a análise dos dados coletados e para a investigação sobre o desenvolvimento da tecnologia utilizada pela $3^{\mathrm{a}}$ Conferência Nacional de Juventude possibilitou identificar as relações entre as subcategorias do conceito e a necessidade de alargá-las, para que possam dar conta de algumas questões observadas.

Um primeiro exemplo disso trata das relações entre a Capacidade de Tecnologia e a Capacidade de Gestão do Processo Participativo quando se analisa o papel de revisão sobre os códigos produzidos do ponto de vista dos contratos firmados pela Administração Pública. Independentemente do tipo de instrumento (contrato com a empresa pública, através de licitação, por consultoria etc), o órgão contratante se torna responsável por avaliar as entregas e autorizar o pagamento. Ocorre que o desenvolvimento de tecnologias demanda, da Administração Pública, não apenas a capacidade de avaliar os efeitos práticos do artefato, mas também o processo de desenvolvimento e a qualidade dos artefatos produzidos.

A contratação de desenvolvimento de software também levantou uma discussão sobre as capacidades administrativas que permitem tal ação por parte do Estado. A escolha pelo uso do contrato com o Serpro e pela mobilização de consultores, no caso estudado, respondeu a questões bastante específicas sobre as exigências de prazo, sobre o software que a SNJ já utilizava e sobre os recursos financeiros já previstos e alocados. Se a utilização de tais instrumentos de certa maneira antecedeu o próprio caso - pois tanto o contrato com o Serpro e a disponibilidade de consultores já existiam - as entrevistas revelam que ambos foram escolhidos cuidadosamente pela SNJ para viabilizar a mobilização de certos recursos. Em outras palavras, o debate sobre os instrumentos de contratação disponíveis na gestão pública se revelou importante para a investigação de processos que utilizam TICs e para a compreensão sobre as capacidades estatais mobilizadas e mesmo para a escolha das tecnologias empregadas. Essa questão pode, inclusive, constituir uma subcategoria das Capacidades Administrativas. 
Também se notou uma relação entre as Capacidades de Tecnologia e de TI na Administração Pública (STEFANI, 2015) no que se refere ao papel de comunidade desempenhado pela empresa pública de desenvolvimento, o Serpro, em relação ao software Noosfero. Essa questão foi detalhada no Capítulo 4 e se refere ao fato de que o Serpro passou a prestar serviços e firmar contratos de desenvolvimento para oferecer soluções que utilizassem Noosfero, sendo responsável pela hospedagem e pela manutenção de diferentes iniciativas (Participa.br, Portal da Juventude, etc) e pelo repositório comum destas iniciativas, chamado de Noosfero Gov, no qual o Serpro tinha grande protagonismo. Em outras palavras, a experiência e a especialização de sua equipe em projetos que utilizavam o software constituíram grande incentivo para que os órgãos da Administração Pública Federal contratassem o Serpro para desenvolvimento, hospedagem e/ou manutenção. Justamente por oferecer soluções de hospedagem e de manutenção, se tornando assim responsável pela atualização e pelo funcionamento das soluções existentes, houve incentivos para que o Serpro assumisse um papel mais ativo na comunidade do Noosfero Gov, contribuindo com o assessoramento e a revisão dos códigos produzidos por outras iniciativas governamentais. Dessa forma, além de se manter em posição de centralidade para oferecer serviços de hospedagem e manutenção, preservar seu reconhecimento pela comunidade e continuar altamente especializado para oferecer desenvolvimento, o Serpro pôde evitar conflitos e externalidades negativas advindas de outras iniciativas, preservando as soluções para as quais a empresa já oferecia hospedagem e manutenção.

O caso revelou, portanto, dois tipos de incentivos distintos à empresa supracitada: manter-se a par das melhorias produzidas pelos diferentes participantes da comunidade e deter relevância para influenciar nas soluções elaboradas e na estrutura tecnológica dominante, o que se obtém a partir das contribuições, da reputação da empresa e do conhecimento sobre o software; além do incentivo direto do negócio, pelo fato de o Serpro oferecer serviço de hospedagem e manutenção e, dentro da comunidade Noosfero Gov, se colocar como um dos principais "provedores" deste serviço, responsável direto por garantir que as distintas aplicações em desenvolvimento não afetassem negativamente umas as outras e, pelo contrário, gerassem benefícios passíveis de aproveitamento. Nesse sentido, pode-se dizer que o caso serviu para consolidar no Serpro uma capacidade estatal de desenvolvimento e gestão de projetos em Noosfero, oferecendo uma espécie de provimento unificado, haja vista o 
Participa.br se constituir como uma ferramenta à disposição dos órgãos e ministérios para realização de suas consultas.

O provimento unificado de soluções de tecnologia é uma das recomendações contidas no Relatório da Auditoria Operacional realizada mediante autorização do Tribunal de Contas da União exarada no Acórdão n ${ }^{\circ}$ 505/2015 (TCU, 2015), como forma de reduzir os custos e as recorrências do desenvolvimento de novas soluções específicas por parte de cada órgão, mesmo quando há questões semelhantes ou certa compatibilidade e complementaridade entre soluções:

220.1. recomendar à Secretaria de Logística e Tecnologia da Informação do Ministério do Planejamento, Orçamento e Gestão que:

220.1.1. efetue levantamento a fim de identificar demandas de soluções de TI comuns às organizações do Sisp, com vistas a analisar a oportunidade, a conveniência e a viabilidade de implementar o provimento de modo padronizado ou centralizado dessas soluções para as organizações do Sisp; (TCU, 2015, p. 33, seção $3.1)$

O caso estudado se valeu desse provimento pois, embora tenham sido mobilizados consultores externos para o desenvolvimento de funcionalidades e de código-fonte, o próprio Serpro foi contratado para tarefas de desenvolvimento e era o responsável pela manutenção e pela hospedagem do mesmo (antes e durante o projeto). Portanto, a existência de um repositório comum oferecia incentivos e benefícios tanto para o Serpro, quanto para as demais iniciativas.

Além dos benefícios já apresentados, vale destacar concretamente duas funcionalidades desenvolvidas para a $3^{\text {a }}$ Conferência Nacional de Juventude que também faziam parte dos objetivos de desenvolvimento estabelecidos pelo Serpro: gameficação e campos customizados de cadastro. Ambas foram funcionalidades essenciais para a $3^{\text {a }}$ Conferência e portanto foram objeto do trabalho do time de desenvolvedores. Contudo, o próprio Serpro já vinha iniciando esforço para o desenvolvimento de gameficação no Noosfero e considerava essa frente necessária para atender as demandas dos projetos que já utilizavam o software, de modo a estimular maior engajamento dos participantes, a possibilitar uma metáfora de jogo (com pontuação, reputação, premiações simbólicas de acordo com as atividades realizadas) e também a ressaltar o feedback por parte dos órgãos. $\mathrm{O}$ trabalho já iniciado e planejado pelo Serpro beneficiou a equipe de consultores e ambas as equipes interagiram para conceber e especificar as melhores soluções. O resultado do trabalho dos consultores passou então a ser incorporado pela versão comum do Noosfero Gov, 
passando a ser uma funcionalidade disponível não apenas para a Conferência de Juventude, mas para todas as iniciativas que assim desejassem e ativassem tal funcionalidade.

Já a funcionalidade de campos customizados de cadastro foi uma necessidade demandada pela SNJ e objeto da produção dos consultores. Por ser uma funcionalidade a ser desenvolvida no backend, recebeu apoio de Leandro Nunes na especificação e na revisão do código. A funcionalidade também foi avaliada como sendo de grande valor para o Noosfero Gov, com potencial de beneficiar todo o conjunto das iniciativas, o que de fato ocorreu (segundo relatos das entrevistas de Ricardo Poppi, 2016 e 2017). Trata-se mais uma vez de um caso no qual o Serpro atuou, através de sua equipe, como revisor e orientador do processo de produção, colaborando com os consultores. Há, aqui, uma espécie de zona cinzenta pois, ao mesmo tempo que essa atividade não era diretamente remunerada (não equivalendo a Pontos de Função), gerava valor para o Serpro, constituindo ao mesmo tempo melhorias para o software, reputação e centralidade de sua equipe e benefícios que otimizavam atividades de desenvolvimento executadas pelo Serpro, estas, sim, remuneradas.

Uma quarta questão destacada pela investigação sobre o desenvolvimento da tecnologia utilizada pela $3^{\text {a }}$. Conferência Nacional de Juventude se refere às capacidades estatais de Recursos Humanos em relação às Capacidades de Tecnologia ou, mais precisamente, sobre como foram mobilizados recursos humanos específicos por parte da SNJ a partir da escolha do uso do Noosfero, que implicava a necessidade de mobilizar uma equipe com experiência em Noosfero, preferencialmente de pessoas com destacada atuação na comunidade do software ou com envolvimento anterior em projetos governamentais que utilizaram essa tecnologia.

A mobilização de conhecimentos específicos sobre tecnologias, metodologias e linguagens se mostrou importante no caso investigado, pois se revelou como um dos objetivos buscados pela SNJ. Alcançada pelo instrumento de consultoria, essa mobilização estabelece vínculo temporário entre consultor e órgão, restringindo-se a projetos ou atividades determinadas. São características bastante específicas de Recursos Humanos observadas na pesquisa e que ajudam a alargar a compreensão sobre essa subcategoria dentro do constructo teórico de Stefani (2015).

Ainda sobre essa correlação observada entre Capacidades de Recursos Humanos e de Tecnologia, o caso e as entrevistas revelaram como o instrumento da consultoria tem sido 
utilizado como uma capacidade para mobilizar recursos humanos necessários para o desenvolvimento tecnológico, ainda que não tenha exatamente essa finalidade.

As entrevistas revelaram, por exemplo, que os desenvolvedores que se tornaram consultores deveriam, por contrato, produzir relatórios descritivos sobre os códigos desenvolvidos. Em outras palavras, embora tenham sido mobilizados com o objetivo de produzirem códigos e artefatos tecnológicos, o vínculo contratual e mesmo o produto que viabilizava pagamento e prestação de contas seriam relatórios descrevendo as funcionalidades e o trabalho realizado. Os conteúdos dos repositórios de código e o próprio código-fonte ${ }^{47}$, por outro lado, não configuravam produto do ponto de vista do instrumento de contratação.

Assim, tal instrumento não oferece a possibilidade de a remuneração estar atrelada à qualidade dos códigos produzidos e gera um trabalho adicional aos desenvolvedores, que precisam dedicar parte de seu tempo para a produção dos relatórios descritivos - que via de regra obedecem ou seguem uma estrutura quase acadêmica e têm entre 30 e 50 páginas. Em termos práticos, o risco de consultores produzirem relatórios e cumprirem as exigências formais mesmo que apresentando baixa dedicação e baixa qualidade no desenvolvimento existe pois o instrumento não possibilita, como foi dito, nenhum tipo de análise deste tipo ou sanções decorrentes daí.

No caso da $3^{\text {a }}$ Conferência Nacional de Juventude o que se pôde observar foi a minimização deste risco desde o processo de seleção (com edital que priorizou a experiência com o software e na comunidade do Noosfero, possibilitando a análise sobre a reputação dos inscritos), passando por um acompanhamento mais técnico da SNAS (cujo gestor detinha conhecimentos técnicos) e principalmente pelo papel desempenhado pelo servidor do Serpro na revisão, no controle das versões e do que era produzido. Apenas a primeira ação é intrínseca ao instrumento de contratação e as demais, que se mostraram decisivas, dependeram de uma mobilização possível graças às características de um software livre, do papel desempenhado pelo Serpro em relação ao Noosfero, do lócus da SNJ dentro da Secretaria Geral da Presidência da República e, em alguma medida, do ativismo e da decisão individual dos atores envolvidos.

\footnotetext{
Código-fonte (source code em inglês) é o conjunto de palavras ou símbolos escritos de forma ordenada, contendo instruções em uma das linguagens de programação existentes, de maneira lógica. Existem linguagens que são compiladas e as que são interpretadas. As linguagens compiladas, após ser compilado o código fonte, transformam-se em software, ou seja, programas executáveis. Este conjunto de palavras que formam linhas de comandos deverá estar dentro da padronização da linguagem escolhida, obedecendo critérios de execução.
} 
Menos do que propor uma revisão do conceito de Capacidades de Governo Relacionadas à Utilização de TICs em Processos de Participação Social (CGTPS) proposta por Stefani (2015) e que se mostrou útil dos pontos de vista teórico e metodológico para essa investigação, estas questões apontam possibilidades de ampliação do conceito. 


\section{CONCLUSÕES}

A presente pesquisa se debruçou sobre o processo de produção da tecnologia empregada na $3^{\text {a }}$ Conferência Nacional de Juventude, que se caraceterizou pelo envolvimento de diferentes organizações ligadas à Administração Pública Federal, de indivíduos mobilizados por ela e com vínculo transitório em função do projeto, bem como de indivíduos pertencentes à comunidade do software livre Noosfero mas que não tiveram nenhum tipo de vínculo com o projeto ou qualquer das suas organizações participantes. Além disso, o caso se caracterizou pela atuação não remunerada da equipe do Serpro ao executar funções de revisão de código e de assessoramento. Tais elementos caracetrizam a existência do que esta pesquisa entende por coprodução (OSTROM, 1996) e possibilitaram a investigação sobre quais foram e como foram mobilizadas as capacidades estatais necessárias à coprodução da tecnologia em questão.

No estudo do caso foi possível identificar as relações entre as capacidades de Tecnologia, TI na Administração Pública e Recursos Humanos, que compõem o conceito Capacidades de Governo Relacionadas à Utilização de TICs em Processos de Participação Social (CGTPS) desenvolvido por Stefani (2015). A mobilização desses três tipos de capacidades estatais foi possível graças ao papel de comunidade e de revisão de código-fonte desempenhado pelo Serpro e graças também ao instrumento de consultoria através de acordos de cooperação técnica internacional.

Para sintetizar o processo de desenvolvimento da tecnologia utilizada pela $3^{\mathrm{a}}$. Conferência de Juventude: foi desenvolvida a partir da contratação do Serpro,que utilizou uma pequena parte dos pontos de função já disponíveis em contrato com a Presidência da República, e graças à contratação de desenvolvedores através do instrumento de consultoria utilizado pela SNJ. Ambos, Serpro e consultores, produziram código-fonte, desenvolvendo novas funcionalidades no Portal da Juventude (que utilizava Noosfero), no backend do Noosfero e no frontend em Ionic/AngularJS.

A atuação do Serpro, no entanto, não se resumiu à produção e publicação de códigofonte (objeto do contrato que utilizou a métrica de Pontos de Função) e que poderia ser analisado apenas como uma capacidade de TI na Administração Pública (que se relaciona com a capacidade em Recursos Financeiros e Físicos existente para mobilizar a empresa pública). No caso, a atuação do Serpro se extendeu ao assessoramento da equipe de consultores e na 
revisão e aprovação do código produzida por ela. Tal capacidade é ao mesmo tempo de Tecnologia e não estava formalmente disponível para a SNJ e sua constituição foi possível graças ao fato de que o Serpro estava implicado no software não apenas pelo projeto (e pelo contrato) em questão. O Serpro na realidade é responsável pela hospedagem e pela manutenção do conjunto de serviços e projetos que utilizam o Participa.br para a APF e, por essa razão, o trabalho dos consultores recebia apoio do Serpro para antecipar problemas, dirimir conflitos e indicar soluções. Os códigos produzidos pelos consultores eram posteriormente revisados pelos servidores do Serpro na medida em que teriam de ser incorporados ao repositório comum das iniciativas governamentais em Noosfero (Noosfero Gov), com potencial impacto para o conjunto de iniciativas.

Há, aqui, uma espécie de zona cinzenta pois, ao mesmo tempo que essa atividade não era diretamente remunerada (não equivalendo a Pontos de Função), gerava valor para o Serpro, constituindo ao mesmo tempo melhorias para o software, reputação e centralidade de sua equipe e benefícios que otimizavam outras atividades de desenvolvimento executadas pelo Serpro, estas, sim, que eram remuneradas. Tal zona cinzenta, na verdade, é comum em comunidades de software livre nas quais há uma multiplicidade de atores e iniciativas em desenvolvimento utilizando uma versão comum do software e se beneficiando das atualizações dessa versão comum, como é o caso do Noosfero Gov.

Um software cuja comunidade tem essa característica permite que seus membros possam aperfeiçoar funcionalidades e códigos para responder às demandas específicas de seus projetos, ao mesmo tempo em que essas contribuições acabam sendo revisadas e analisadas pelos desenvolvedores mais experientes, que acumulam uma espécie de função na comunidade (por mérito), aprovando tais contribuições e as incorporando à versão comum do software.

Dessa forma, é possível afirmar que um dos principais papéis exercidos no processo de construção de um software livre quando há coprodução está justamente no exercício deste papel de assessorar e influenciar a produção e de revisar e autorizar as contribuições, controlando a versão pública do software. São atividades que encontram na literatura da Construção Social da Tecnologia (PINCH e BIJKER, 1984) todo um debate em torno dos conceitos de estabilização e fechamento de uma tecnologia e sobre o papel dos grupos sociais na disputa sobre a flexibilidade interpretativa existente e sobre a estrutura tecnológica que se torna dominante a partir do fechamento. 
Essa atuação de comunidade exercida especialmente pelo Serpro no caso investigado, como já foi dito, não estava prevista em contrato e, segundo as entrevistas de Ricardo Poppi e de Leandro Nunes, não há conhecimento sobre instrumentos dentro dos contratos que utilizam Pontos de Função para remunerar essas atividades. Houve, no caso estudado, e há, aparentemente na Administração Pública, uma espécie de ausência de capacidade neste ponto, sem a qual o Estado não consegue mobilizar estes recursos sem depender de uma boa dose de ativismo e de decisão pessoal dos desenvolvedores implicados (como apontaram as entrevistas com Ricardo Poppi e Leandro Nunes), pois mesmo no caso do Serpro não há mecanismos próprios de incentivo para essa atividade.

A capacidade de Tecnologia, por tanto, precisa incorporar os sentidos do que significa a o pepal de comunidade (atuação em uma comunidade de software) e tal papel, ao mesmo tempo, se relaciona com capacidades de TI na Asministração Pública e Recursos Humanos.

Isso posto, para além da atuação do Serpro foi possível perceber como o instrumento de consultoria vinculado a acordos de cooperação técnica internacional foi utilizado pela equipe da Secretaria Nacional de Juventude em prol da formação da equipe responsável pelo desenvolvimento da tecnologia utilizada na $3^{\text {a }}$ Conferência Nacional de Juventude. Com efeito, praticamente toda a força de trabalho dedicada ao desenvolvimento tecnológico foi mobilizada através daquele instrumento que, a partir das entrevistas e da análise documental, se revelou presente também em outros casos semelhantes dentro da Administração Pública Federal (Participa.br; CONAE ${ }^{48}$, CONSOCIAL ${ }^{49}$ ). Em outras palavras, a Capacidade de Tecnologia e de Recursos Humanos necessárias no caso foram mobilizadas graças ao instrumento de consultoria, em si instrumento de gestão que se relaciona com Capacidades Financeiras e Físicas.

No caso estudado a adesão prévia ao Noosfero e a existência do Portal da Juventude implicavam a necessidade da utilização desta tecnologia e de seu aperfeiçoamento, utilizando o Noosfero enquanto backend. A mobilização de consultores buscava responder a necessidade de constituição de uma equipe com o mínimo de entraves ou dificuldades para inovação e altamente especializada em desenvolvimento de softwares, mais precisamente com experiência em Noosfero e em projetos governamentais que tenham utilizado Noosfero.

\footnotetext{
$48 \quad$ A Conferência Nacional de Educação (CONAE) foi realizada em 2014 pelo Poder Público e articulada com a sociedade para que todos pudessem participar do desenvolvimento da Educação Nacional.

$49 \quad$ A $1^{\text {a }}$ Conferência Nacional sobre Transparência e Controle Social ( $1^{\text {a }}$ Consocial) foi um processo nacional coordenado pela Controladoria-Geral da União (CGU).
} 
O que se observou é que o instrumento de consultoria foi decisivo para a mobilização deste recurso, constituindo capacidades de Tecnologia, de Recursos Humanos e impactando ainda na Capacidade da TI na Administração Pública, segundo as categorias apresentadas por Stefani (2015) e a partir de uma abordagem relacional que entende tais capacidades como sendo "recursos para a ação estatal que podem ser mobilizados tanto no Estado como na sociedade, podendo estar disponíveis em certos momentos e posteriormente indisponíveis" (SOUZA, 2016, p. 15).

Está aí a principal vantagem do instrumento de consultoria e que foi destacada nas entrevistas: a possibilidade de construir chamadas públicas que definam critérios de experiência e de conhecimentos bastante específicos, mobilizando determinadas comunidades ou grupos de profissionais que atendam às necessidades específicas do projeto em questão. Para casos em que há uma necessidade de evoluir um software específico, otimizar um processo de desenvolvimento de software ou mesmo mobilizar recursos altamente especializados (os programadores mais renomados e experientes de determinado software) este instrumento se mostra útil, como revelou a investigação.

No caso da $3^{\text {a }}$ Conferência Nacional de Juventude aliás, o instrumento garantiu a mobilização de profissionais que já trabalhavam com Noosfero e com experiências prévias necessárias para diminuir a curva de aprendizagem e otimizar o processo de entregas. No entanto, como foi apresentado, formalmente o instrumento não possibilita a remuneração de código-fonte e suas exigências inclusive acarretam a necessidade de que os desenvolvedores dediquem parte de seus recursos para atividades outras, de modo a construir os produtos exigidos pelo instrumento (relatórios descritivos).

A conclusão, neste ponto, é que é necessário dotar a Administração Pública de instrumentos de contratação formais e adequados a esse tipo de situação, pois o instrumento de consultoria é uma espécie de improvisação, dadas as restrições de possibilitar a remuneração dos consultores a partir da análise sobre o código-fonte que produziram. Também se faz necessário debater a criação de instrumentos específicos que estimulem e premiem o papel de comunidade desempenhado por membros da APF ou em suas contratações (casos em que o desenvolvimento tecnológico é realizado por empresas). Deter relevância e influência em uma comunidade de software é crucial para efetivamente se beneficar as melhorias produzidas por tal comunidade e ter algum poder de direcionar seus esforços para responder às demandas do Estado. Deter essa capacidade também afeta a 
qualidade dos códigos-fonte produzidos e contratados e a própria soberania tecnológica, no que se refere às escolhas de manter instâncias e versões próprias, aderir às versões da comunidade etc.

O desenvolvimento de instrumentos mais adequados para esse tipo de situação se coloca como uma questão para debate, haja vista a recente Estratégia de Governança Digital publicada pelo Governo Federal que incentiva, cada vez mais, a participação da sociedade na coprodução de tecnologias utilizadas pelo Estado. Assim, é possível imaginar a adesão do Estado a softwares livres e a possibilidade de que busque mobilizar conhecimentos presentes na comunidade destes softwares em prol de projetos governamentais com resultados diretos não apenas na qualidade dos artefatos produzidos, mas também na possibilidade de tais recursos mobilizados contribuírem para a apropriação tecnológica e o desenvolvimento de novas capacidades por parte do Estado.

\subsection{LIMITAÇÕES DA PESQUISA E POSSIBILIDADES FUTURAS}

Essa pesquisa lançou mão do conceito de Capacidades de Governo Relacionadas à Utilização de TICs em Processos de Participação Social (CGTPS) desenvolvido por Stefani (2015) a partir da investigação sobre a Consulta do Marco Civil da Internet, processo participativo que utilizou tecnologias digitais para a deliberação de propostas e o diálogo entre Estado e Sociedade. De maneira análoga, a presente pesquisa se concentrou na análise sobre a etapa digital da $3^{\text {a }}$ Conferência Nacional de Juventude, que também utilizou tecnologias digitais para a participação social, possibilitando a deliberação de propostas e a seleção de delegados.

Ambos os casos estudados tratam, por tanto, de processos participativos que utilizaram TICs. No entanto, esta pesquisa se concentrou nos aspectos tecnológicos e relacionados à tecnologia desenvolvida e utilizada pela $3{ }^{\text {a }}$ Conferência Nacional de Juventude, analisando as capacidades estatais existentes para a mobilização dos recursos necessários para sua produção. Essa ênfase foi dada sem deixar de lado a investigação sobre as demais categorias e subcategorias que compõem o referencial teórico utilizado. Há, dessa forma, a possibilidade de se comparar resultados e dados de ambas as investigações, desde que de maneira cuidadosa e levando em consideração as limitações para a comparação entre dois 
estudos interpretativos, sendo que um aprofundou e se concentrou mais em determinados aspectos do que o outro.

No entanto, os aspectos políticos fora explorados com menor ênfase, com menos entrevistados que pudessem detalhar as negociações entre SNJ e Conselho Nacional ou mesmo outras questões referentes ao contexto político que se relacionou ao caso. Trata-se de uma limitação do presente trabalho.

Cabe destacar ainda que o conceito de Capacidades de Governo Relacionadas à Utilização de TICs em Processos de Participação Social (CGTPS) desenvolvido por Stefani (2015) se revelou um construto teórico e metodológico útil para a análise de processos participativos que utilizam TICs desenvolvidas pela Administração Pública. É possível utilizálo para outros estudos interpretativos de casos únicos, múltiplos casos ou mesmo para a análise comparativa.

A existência de coprodução do software, ou seja, o envolvimento de indivíduos ligados a diferentes organizações no processo de produção do artefato também pode ser investigada do ponto de vista dos repositórios de código e do o código-fonte produzido, que podem ser analisados em relação à sua autoria, às organizações com as quais os autores estão ligados e aos atores responsáveis pela revisão e aprovação. Essa análise sobre o controle das versões pode contribuir para a compreensão sobre a hierarquia, os processos de poder e de decisão que permeiam um processo desse tipo e ilustrar os benefícios e o valor apropriado pela Administração Pública Federal. Trata-se, ao mesmo tempo, de uma limitação da presente pesquisa e uma possibilidade para investigações complementares ou futuras.

Tais comunidades de software podem ainda ser investigadas enquanto redes de interação e tal abordagem pode ser útil na compreensão dos perfís típicos e das relações existentes, contribuindo para o debate sobre a atuação do Estado dentro destas comunidades e as capacidades estatais necessárias para tal. Ou seja, é possível estudar objetos similares ao escohido pela presente pesquisa a partir das teorias de redes e comunidades de políticas públicas e a partir da SCOT, do ponto de vista dos processos de construção dos artefatos.

Outra linha de investigação possível tem relação com o tipo de software escolhido como objeto da pesquisa. É possível imaginar que a análise de um software que tenha status de tecnologia estratégica para a Administração Pública Federal seja mais revelador sobre os esforços empreendidos pelo Estado para manter influência na construção social desta tecnologia, influenciando a flexibilidade interpretativa da comunidade, a manutenção da 
estrutura tecnológica do software e, em especial, atuando no processo de estabilização e de fechamento da tecnologia. Não foi exatamente o caso específico do software estudado por este trabalho, a julgar pela interpretação de alguns dos principais atores envolvidos em seu desenvolvimento (entrevistas de Leandro Nunes e Ricardo Poppi).

A pesquisa de um software assumido pela APF como estratégico e que esteja sendo utilizado e desenvolvido há mais tempo poderia apontar melhor para as capacidades estatais existentes e os mecanismos de; mobilização dos recursos estratégicos que garantiriam controle sobre versão; estímulo para que a comunidade produza valor que beneficie os objetivos dos projetos governamentais; atração dos desenvolvedores mais especializados e com maior reputação (que têm poder na comunidade); e mesmo a retenção deste conhecimento e destes desenvolvedores pela APF, entre outras questões possíveis para pesquisas.

Tratam-se de considerações sobre as limitações que constituíram a presente pesquisa e que, ao mesmo tempo, a partir dos resultados da investigação empreendida, apontam algumas possibilidades para futuros esforços. 


\section{REFERÊNCIAS ${ }^{50}$}

AGUNE, R.; CARLOS, J. Governo eletrônico e novos processos de trabalho. In: LEVY, E.; DRAGO, P. (Org.). Gestão pública no Brasil contemporâneo. São Paulo: Fundap, 2005.

ALFORD, John. Engaging Public Sector Clients. From Service-Delivery to Co-production. Houndmills: Palgrave Macmillan UK, 2009, 261 p.

The Multiple Facets of Co-Production: Building on the work of Elinor Ostrom. In: Public Management Review. v. 16, n. 3, p. 299-316, 2014.

ALVES, Zélia Mana Mendes Biasoli; SILVA, Maria Helena G. F. Dias da. Análise qualitativa de dados de entrevista: uma proposta. In: Paidéia (Ribeirão Preto), Ribeirão Preto, n. 2, p. 6169, julho de 1992. Disponível em: $<$ http://www.scielo.br/scielo.php?

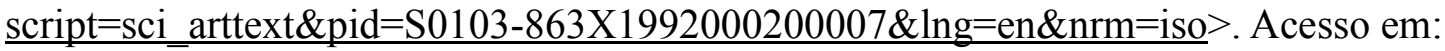
$19 / 01 / 2017$.

AVRITZER, L. Sociedade civil, instituições participativas e representação: da autorização à legitimidade da ação. In: Dados vol. 50, n. 3, 2007. Universidade Cândido Mendes. Rio de Janeiro, Brasil, p. 443-464.

Conferências Nacionais: Ampliando e Redefinindo os Padrões de Participação Social no Brasil. In: AVRITZER, L. (Org.). Conferências Nacionais: atores, dinâmicas participativas e efetividade. Brasília: Ipea, 2013.

BENAKOUCHE, Tamara; MORAES, Ricardo Alexandre Reinaldo de; GUESSER, Adalto Herculano. Software livre numa perspectiva sociotécnica: um estudo preliminar das controvérsias para a resolução de disputas políticas. In: $5^{\circ}$ Workshop sobre Software Livre WSL 2004 / 5 Fórum Internacional Software Livre - FSL 2004. Porto Alegre: Evangraf Ltda, 2004. p. 17-20.

BENKLER, Yochai. La riqueza de las redes: Cómo la producción social transforma los mercados y la libertad. Barcelona: Icaria, 2015.

. The Wealth of Networks: How Social Production Transforms Markets and Freedom. New Haven: Yale University Press, 2006.

BEZERRA, Carla. Entrevista concedida a Henrique Carlos Parra Parra Filho. Meio digital, 30 de junho de 2017.

BICHIR, Renata. Novas agendas, novos desafios: reflexões sobre as relações entre transferência de renda e assistência social no Brasil. In: Novos Estudos Cebrap, Março/2016, n. 104, p. 111-136.

CASTELLS, Manuel. A Sociedade em Rede: do Conhecimento à Política. In: CASTELLS, Manuel; CARDOSO, Gustavo (Org.). A Sociedade em Rede: do conhecimento à ação política; Conferência. Belém: Imprensa Nacional, 2005.

50 De acordo com a Associação Brasileira de Normas Técnicas, NBR 6023 (2002). 
. A Sociedade em Rede. São Paulo: Paz e Terra, 2008.

CHAEBO, Gemael; MEDEIROS, Janann Joslin. Reflexões conceituais em coprodução de políticas públicas e apontamentos para uma agenda de pesquisa. In: $C a d$. EBAPE.BR, Rio de Janeiro, v. 15, n. 3, p. 615-628, Julho 2017 . Disponível em: $<$ http://www.scielo.br/scielo.php?

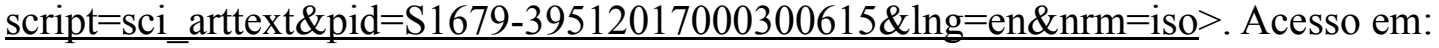
05/01/2018.

CINGOLANI, L. The state of State capacity: a review of concepts, evidence and measures. Maastricht: UNO-MERIT, 2013. (Working Paper n. 53).

COLIVRE. Disponível em: < http://colivre.coop.br/> . Acesso em: 14/02/2018.

COLOMBO, Clelia (2006). Innovación democrática y TIC, ¿hacia una democracia participativa?. In: Segundo Congreso sobre Internet, derecho y política: análisis y prospectiva. IDP. Revista de Internet, Derecho y Política. N.o 3. UOC. Disponível em:

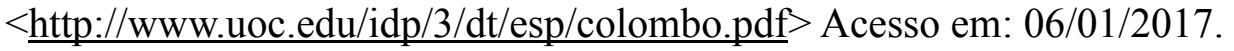

COMITÊ GESTOR DA INTERNET NO BRASIL - CGI.br. Pesquisa sobre o uso das tecnologias de informação e comunicação no setor público brasileiro: TIC governo eletrônico 2015. Coord. Alexandre F. Barbosa. São Paulo: CGI.br, 2016. Disponível em:

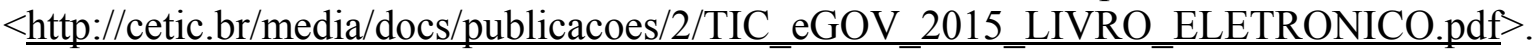
Acesso em: 15/11/2016.

CUNHA, Maria Alexandra. Meios eletrônicos e transparência: a interação do vereador brasileiro com o cidadão e o poder executivo. In: X Congreso Internacional del CLAD sobre la Reforma del Estado y de la Administración Pública, Santiago, Chile, p. 18-21, Out., 2005.

CUNHA, Maria Alexandra Viegas Cortez da; MIRANDA, Paulo Roberto de Mello. O uso de TIC pelos governos: uma proposta de agenda de pesquisa a partir da produção acadêmica e da prática nacional. In: $o \& s$ v.20 - n.66. Salvador, Julho/Setembro 2013, p. 543-566. Disponível em: $<$ http://www.scielo.br/scielo.php?script $=$ sci arttext\&pid $=$ S198492302013000300010\&lng=en\&nrm=iso>. Acesso em: 13/01/2017.

. A Pesquisa no Uso e Implicações Sociais das Tecnologias da Informação e Comunicação pelos Governos no Brasil: uma Proposta de Agenda a Partir de Reflexões da Prática e da Produção Acadêmica Nacional. In: ANPAD n. 32, 2008, Rio de Janeiro. Anais do XXXII EnANPAD 2008. Publicação online. Rio de Janeiro: Disponível em: $<$ http://www.anpad.org.br/admin/pdf/ADI-C1743.pdf $>$. Acesso em: 11/02/18.

CUNHA, Maria Alexandra et al. Projeto Democracia Digital Volume 2: Experiências governamentais brasileiras de participação digital. Escola de Direito de São Paulo da Fundação Getulio Vargas. Grupo de Ensino e Pesquisa em Inovação, 2015.

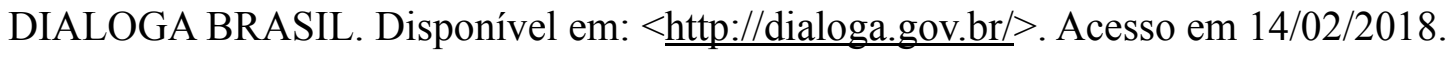


DINIZ, Eduardo Henrique et al. O governo eletrônico no Brasil: perspectiva histórica a partir de um modelo estruturado de análise. In: Revista de Administração Pública, v. 43, n. 1, p. 23 48, 2009.

DINIZ, Vagner. A história do uso da tecnologia da informação na gestão pública brasileira através do CONIP - Congresso de Informática Pública. In: X Congreso Internacional del CLAD sobre la Reforma del Estado y de la Administración Pública, Santiago, Chile, p. 18-21 Oct. 2005. Disponível em: $<$ http://siare.clad.org/fulltext/0052732.pdf $>$. Acesso em: $11 / 02 / 2018$.

EVANS, Peter. O Estado como problema e solução. In: Lua Nova n ${ }^{\circ} 28-29$, São Paulo, Abril 1993.

EVANS, P. B.; RUESCHEMAYER, D.; SKOCPOL, T. (org.). Bringing the State Back in. Cambridge: Cambridge University Press, 1985.

FARIA, Claudia Feres; SILVA, Viviane Petinelli; LINS, Isabella Lourenço. Conferências de políticas públicas: um sistema integrado de participação e deliberação. In: Rev. Bras. Ciênc. Polít., Brasília, n. 7, p. 249-284, Abril 2012. Disponível em:

$<\underline{\text { http://www.scielo.br/scielo.php?script }=\text { sci_arttext\&pid }=\mathrm{S} 0103-}$

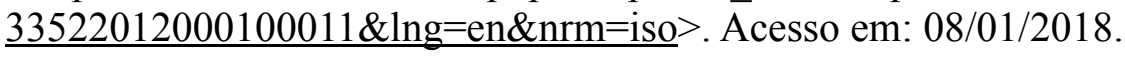

FERGUSON, Martin. Estratégias de Governo Eletrônico: o cenário internacional em desenvolvimento. In: EISENBERG, José; CEPIK, Marco (Org.). Internet e Política: teoria e prática da democracia eletrônica. Belo Horizonte: Editora UFMG, 2002. p. 103-140.

FOUNTAIN, Jane. Questões Centrais no Desenvolvimento Político do Estado Virtual. In: CASTELLS, Manuel; CARDOSO, Gustavo (org). A Sociedade em Rede. Do Conhecimento à Acção Política. Imprensa Nacional - Casa da Moeda. Lisboa, 2005. p. 149-175.

FREITAS, Christiana Soares de. O Software Publico Brasileiro: novos modelos de cooperac? o economica entre Estado e Sociedade Civil. Informação \& Sociedade, v. 22, n. 2, 2012.

FULK, Janet. Social construction of communication technology. In: The Academy of Management journal, v. 36, n. 5. Nova York: Academy of Management 1993, p. 921-950.

GERMANI, Leonardo. Desafios para o desenvolvimento de serviços digitais pelo governo federal brasileiro. Tese de Mestrado. São Paulo: Pontifícia Universidade Católica de São Paulo (PUC-SP), 2016

GIL FLORES, J. Aproximación interpretativa alcontenido de lainformación textual. In: Análisis de datoscualitativos: aplicaciones a lainvestigación educativa. Barcelona: PPU, 1994.

GODOY, A.S. Estudo de caso qualitativo In: GODOI, C.K.; BANDEIRA-DE-MELLO, R.; BARBOSA DA SILVA, A. (Org.). Pesquisa qualitativa em estudos organizacionais. São Paulo: Saraiva, 2006. 
GOMES, Wilson. Internet e participação política em sociedades democráticas. In: Revista FAMECOS, n. 27, agosto/2005.

. Participação política online: Questões e hipóteses de trabalho. In: MAIA, Rousiley Celi Moreira; GOMES, Wilson; MARQUES, Francisco Paulo Jamil Almeida. Internet e participação política no Brasil. Porto Alegre: Sulina. p. 19-45, 2011.

GOMIDE, A; PIRES, R. Capacidades estatais para o desenvolvimento no século XXI. In: Boletim de análise político-institucional, Brasília, n. 2, 2012.

Capacidades estatais e democracia: arranjos institucionais de políticas públicas. Brasília: Ipea, 2014.

GOMIDE, A.; PIRES, R; SÁ E SILVA, F.. Capacidades estatais e políticas públicas: passado, presente e futuro da ação governamental para o desenvolvimento. In: Brasil em desenvolvimento 2014: estado, planejamento e políticas públicas. Brasília: Ipea, 2014.

GRINDLE, Merilee S. Challenging the State: Crisis and Innovation in Latin America and Africa, Cambridge: Cambridge University Press, 1996.

GUIMARÃES, Tomás de Aquino; MEDEIROS, Paulo Henrique Ramos. A relação entre governo eletrônico e governança eletrônica no governo federal brasileiro. In: $\mathrm{Cad}$.

EBAPE.BR, Rio de Janeiro, v.3, n.4, Dezembro/2005, p. 01-18. Disponível em:

$<$ http://www.scielo.br/scielo.php?script $=$ sci arttext\&pid $=\mathrm{S} 1679-$

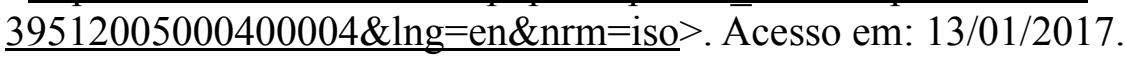

INSTITUTO PÓLIS; INESC. Arquitetura da Participação no Brasil: avanços e desafios. 2011. Disponível em: $<$ http://www.inesc.org.br/biblioteca/textos/relatorio-arquitetura-daparticipacao-social-no-brasil > . Acesso em: 20/07/2014.

INTOSAI (International Organization of Supreme Audit Institutions). Auditing E-government. Viena: Intosai, Standing Committee on IT Audit, Task Force for Auditing E-Government, 2003.

JESSOP, B. Bringing the state back in (yet again): Reviews, revisions, rejections, and redirections. In: International Review of Sociology, 11(2), 2001, p. 149-173.

LANZARA, Arnaldo Provasi. Capacidades Estatais, Trabalho e Seguridade Social: África do Sul, Argentina e Brasil em Perspectiva Comparada. In: Texto para Discussão n. 2052, Brasília: Ipea, 2015. p. 1-54. Disponível em:

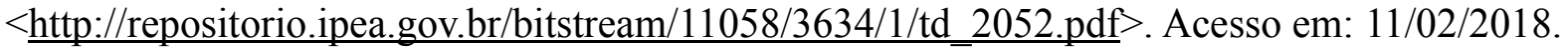

LEMOS, Andre. LÉVY, Pierre. O futuro da Internet: Em direção a uma ciberdemocracia planetária. São Paulo: Paulus, 2010.

LEVITSKY, Steven; MURILLO, María Victoria. Variation in Institutional Strength. In: Annual Review of Political Science n. 12, p. 115-133, 2009. 
LÉVY, Pierre. Pela ciberdemocracia. In: MORAES, Dênis de (org.). Por uma outra comunicação. Rio de Janeiro, Record, 2003. . A esfera pública do século XXI. In: Techyredes. São Paulo: Avina, 2011.

LOGOLINK. Relatório de Pesquisa: Governança eletrônica local - Perspectivas latinoamericanas. Instituto Pólis, 2010 (Mimeo).

LOPEZ, F.; PIRES, R; SÁ E SILVA, F.. A democracia no desenvolvimento e o desenvolvimento da democracia. In: LOPEZ, F.; PIRES, R; SÁ E SILVA, F. (Org.). Estado, Instituições e Democracia: democracia. Brasília: Ipea, 2010.

LOTTA, Gabriela Spanghero. Redes e Parcerias em Políticas Sociais: novos arranjos institucionais de coprodução de serviços nos municípios brasileiros. 2017.

MACHADO, Carlos R. et al. Uso de Software Livre no Governo Federal: Investigando o Estágio Atual e definindo (novos) Parâmetros de Acompanhamento. In: WORKSHOP DE COMPUTAÇÃO APLICADA EM GOVERNO ELETRÔNICO. 2010.

MANN, M. El poder autónomo del Estado: sus orígenes, mecanismos y resultados. Revista Académica de Relaciones Internacionales, Madrid, n. 5, marzo de 2007, GERI - UAM. Disponível em: < $<$ ww.relacionesinternacionales.info/ojs/article/download/59/53.pdf $>$. Acesso em: 15/11/2016.

MARQUES, Francisco Paulo Jamil Almeida. Dimensões da ciberdemocracia: conceitos e experiências fundamentais. Dissertação de mestrado, Bahia, UFBA, 2004.

Debates políticos na Internet: a perspectiva da conversação civil. In: OPINIÃO PÚBLICA, Campinas, vol. 12, no 1, Abril/Maio, 2006, pp. 164-187.

Participação política e internet: meios e oportunidades digitais de participação civil na democracia contemporânea, com um estudo de caso do estado brasileiro. Tese de Doutorado, Bahia, UFBA, 2008.

MATUS, C. Política, planejamento e governo. (Tomo I e II) Brasília: IPEA, 1993. . Adiós, señor presidente. Caracas: Fundación Altadir, 1994. . O plano como aposta. In: PAGNUSSAT, José Luiz; GIACOMONI, James. (Org) Planejamento e orçamento governamental. Coletânea, v. 1. 1. ed. Brasília: Escola Nacional de Administração Pública, 2006. p. 115-144.

MEDINA, Gabriel. Entrevista concedida a Henrique Carlos Parra Parra Filho. Meio digital, 15 de agosto de 2017.

MELO, Hugo. Entrevista concedida a Henrique Carlos Parra Parra Filho. Meio digital, 29 de junho de 2017.

MELO, Marcus A. Governance e reforma do Estado: o paradigma agente x principal. In: Revista do Serviço Público, Brasília, ano 47, v. 120, n. 1, p. 67-82, jan./abr. 1996. 
MILES, M. B.; HUBERMAN, A. M. Qualitative data analysis: a sourcebook of new methods. Newbury Park, California, 1984.

NAÇÕES UNIDAS. Benchmarking E-Government: a global perspective. Nova York: United Nations - Division for Public Economics and Public Administration, American Society for Public Administration, 2002.

NUNES, Leandro. Entrevista concedida a Henrique Carlos Parra Parra Filho. Meio digital, 14 de agosto de 2017.

OSTROM, E. Crossing the great divide: coproduction, synergy, and development. World Development, v. 24, n. 6, pP. 1073-1087, 1996.

PARTICIPA.BR. Disponível em: < http://participa.br/> . Acesso em: 14/02/18.

PEIXOTO, Tiago, WEGENAST, Tobias Albuquerque. Democracia eletrônica no Brasil e no mundo. In: Revista do Legislativo, 2010.

PEREIRA, A. A construção de capacidade estatal por redes transversais: o caso de Belo Monte. Tese de doutorado, Brasília, Universidade Federal de Brasília, 2014.

PINCH, Trevor J.; BIJKER, Wiebe E. The Social Construction of Facts and Artefacts: or How the Sociology of Science and the Sociology of Technology Might Benefit Each Other. Social Studies of Science, vol. 14, n. 3, p. 399-441, 1984.

PINHO, José Antonio Gomes. Internet, governo eletrônico, sociedade e democracia no Brasil: algumas questões básicas em debate. In: Revista VeraCidades, n. 3, Maio de 2008.

POPPI, Ricardo. Entrevista concedida a Henrique Carlos Parra Parra Filho. Jundiaí, 14 de outubro de 2016. 2017. . Entrevista concedida a Henrique Carlos Parra Parra Filho. São Paulo, 12 de agosto de

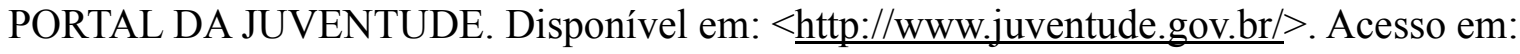
$14 / 02 / 2018$.

PORTAL DO SOFTWARE PÚBLICO. Disponível em:

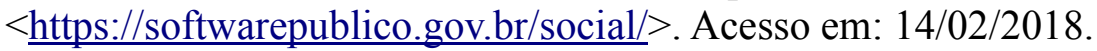

QUEIROZ, M. I. P. Relatos orais: do "indizível” ao "dizível”. In: Ciência e Cultura, 30 (3), São Paulo, 1987, p. 279-286.

RANGEL, Fabiano. Entrevista concedida a Henrique Carlos Parra Parra Filho. Meio digital, 4 de julho de 2017.

RIBEIRO, Manuella Maia. As Relações entre Governo e Sociedade Civil através da Web: Modelos de Relacionamento na Esfera Pública Virtual. Dissertação de Mestrado, São Paulo, 
Fundação Getúlio Vargas, 2012. Disponível em:

$<$ http://bibliotecadigital.fgv.br/dspace/bitstream/handle/10438/9485/ManuellaMaiaRibeiro_Di sserta\%C3\%A7\%C3\%A3odemestrado_CMAPG_FGVSP.pdf? sequence=1\&isAllowed $=\mathrm{y}>$. Acesso em: 11/02/2018.

RONALDO, Marcos. Entrevista concedida a Henrique Carlos Parra Parra Filho. Meio digital, 29 de junho de 2017.

RUEDIGER, Marco Aurélio. Governo Eletrônico ou Governança Eletrônica - Conceitos Alternativos no Uso das Tecnologias de Informação para o Provimento de Acesso Cívico aos Mecanismos de Governo e da Reforma do Estado. In: CONCURSO DE ENSAYOS Y MONOGRAFÍAS DEL CLAD SOBRE REFORMA DEL ESTADO Y MODERNIZACIÓN DE LA ADMINISTRACIÓN PÚBLICA, 16., 2002, Caracas. Anais eletrônicos. Caracas: Centro Latinoamericano de Administración para el Desarollo (CLAD), 2002. 1 CD-ROM.

SACRAMENTO, Caio. Entrevista concedida a Henrique Carlos Parra Parra Filho. Meio digital, 30 de setembro de 2016. 2017. Entrevista concedida a Henrique Carlos Parra Parra Filho. Meio digital, 4 de julho de

SALM, José Francisco; MENEGASSO, Maria Ester. Os modelos de administração pública como estratégias complementares para a coprodução do bem público. In: Revista de Ciências da Administração, v. 11, n. 25, p. 83, 2009.

Proposta de modelos para a coprodução do bem público a partir das tipologias de participação. In: Encontro ANPAD n. 34, 2010. Anais do XXXIV ENANPAD, 2010.

SECRETARIA GERAL DA PRESIDÊNCIA DA REPÚBLICA. Conferências. In: Participação Social. Sem data, sem página. Disponível em:

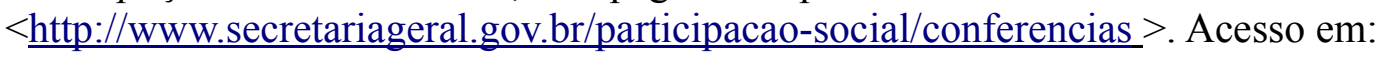
$11 / 02 / 2018$. 2015. . Portaria $\mathrm{N}^{\mathrm{o}}$ 12, de 17 de junho de 2015. In: Diário Oficial da União, 18 de junho de SNJ (SECRETARIA NACIONAL DE JUVENTUDE). Conferência. Sem data, sem página. In: Portal da Juventude. Disponível em: $<$ http://juventude.gov.br/profile/conferencia $>$. Acesso em: 11/02/18.

Notícias. In: Portal da Juventude. Sem data, sem página.Disponível em:

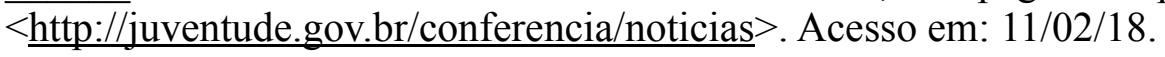

Regimento Nacional. In: Portal da Juventude. 23 de Junho de 2015, sem página.

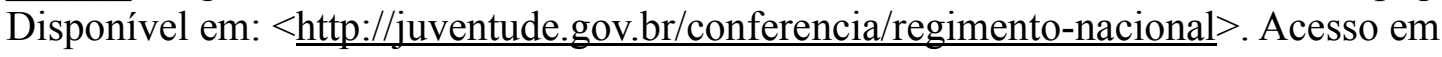
11/02/18. 
Resoluções da CON. In: Portal da Juventude. 26 de Maio de 2015, sem página.

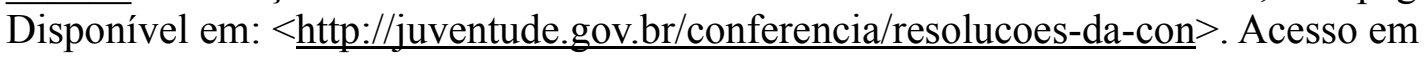
11/02/18.

Etapas. In: Portal da Juventude. 11 de Junho de 2015, sem página. Disponível em: $<$ http://juventude.gov.br/conferencia/etapas/>. Acesso em 11/02/18.

. A experiência de jovens no app \#3ConfJuv - Parte 2. In: Portal da Juventude. 4 de Dezembro de 2015, s.p. Disponível em: $<$ http://juventude.gov.br/juventude/noticias/aexperiencia-de-jovens-no-app-3 confjuv-parte-2>. Acesso em: 12/02/18.

SHIRKY, Clay. Lá vem todo mundo: o poder de organizar sem organizações. Rio de Janeiro: Zahar, 2012.

SKOCPOL, T. Bringing the state back in: strategies of analysis in current research. In: EVANS, P. B.; RUESCHEMAYER, D.; SKOCPOL, T., EDITORS. Bringing the State Back in. Cambridge: Cambridge University Press, 1985.

SOIFER, Hillel. e HAU, Matthias vom. Unpacking the Strength of the State: The Utility of State Infrastructural Power. In: Studies in Comparative International Development, Vol. 43, p. 219-230, 2008.

SOUZA, Clóvis H. L. de et al. Conferências típicas e atípicas: um esforço de caracterização do fenômeno político. In: AVRITZER, Leonardo; SOUZA, Clóvis Henrique L. de. (Org.). Conferências Nacionais: atores, dinâmicas participativas e efetividade. Brasília: Ipea, 2013. p. 25-57. Disponível em:

$<\underline{\text { http://repositorio.ipea.gov.br/bitstream/11058/2520/1/Livro_Conferencias Nacionais- }}$ atores din $\% \mathrm{C} 3 \% \mathrm{~A} 2 \mathrm{micas}$ participativas e efetividade.pdf $>$. Acesso em: 11/02/18.

Capacidades estatais para a promoção de processos participativos: uma análise da forma de organização de conferências nacionais. 2016. Tese de Doutorado em Ciência Política. Brasília: Universidade de Brasília, 2016.

STAKE, Robert E.. Pesquisa qualitativa: estudando como as coisas funcionam. Tradução de Karla Reis, Revisão técnica de Nilda Jacks. Porto Alegre: Artmed, 2011.

STEFANI, Anita. Utilização de TICs em processos participativos no Brasil sob a ótica de capacidades de governo. Tese de doutorado. São Paulo: Universidade de São Paulo. 2015.

STI (SECRETARIA DE TECNOLOGIA DA INFORMAÇÃO). Instrução Normativa SLTI/MP N ${ }^{\circ} 4$ de 11 de Setembro de 2014. Disponível em: Disponível em: $<$ https://www.governoeletronico.gov.br/documentos-e-arquivos/1\%20-\%20IN \%204\%20\%2011-9-14.pdf $>$. Acesso em: 11/02/18.

. Guia de Boas Práticas em Contratação de Soluções de Tecnologia da Informação. v. 3.0. 2017a. Disponível em: $<$ http://www.planejamento.gov.br/noticias/lancada-nova-versaodo-guia-de-boas-praticas-em-contratacao-de-solucoes-deti/guia de boas_praticas_v08.pdf/view>. Acesso em: 11/02/2018. 
Boas práticas, vedações e orientações para contratação de serviços de desenvolvimento e manutenção de software (Fábrica de Software). Documento vinculado à Portaria MP/STI no 20, de 14 de junho de 2016. Brasília, 2017 b.

STRUECKER, Denise Regina; HOFFMANN, Micheline Gaia. Participação social nos serviços públicos: caracterização do estado da arte por meio da bibliometria e da revisão sistemática. In: REGE-Revista de Gestão, v. 24, n. 4, 2017, p. 371-380.

TCU - TRIBUNAL DE CONTAS DA UNIÃO. Estudo dos parâmetros utilizados em acordos de cooperação técnica internacional, financiados exclusivamente com recursos nacionais. Identificação de Acordos de Cooperação Internacional destinados ao exercício de atividades meramente administrativas. Determinações. Considerações. Acórdão: 1339/2009-TCUPlenário. Brasília: TCU, 17/06/2009.

. Relatório de Auditoria natureza operacional. Avaliação dos serviços prestados aos cidadãos de forma eletrônica. Identificação de oportunidades de melhoria. Recomendações. Acórdão: 916/2015-TCU-Plenário. Brasília: TCU, 22/4/2015.

. Auditoria de natureza operacional. Avaliação da eficácia e eficiência do modelo de contratação de desenvolvimento e manutenção de sistemas informatizados adotado pelas organizações componentes da Administração Pública Federal (APF), em especial quando utilizados métodos ágeis de desenvolvimento, visando a apresentar entendimentos quanto aos riscos e métricas utilizados. Recomendações. Acórdão 2.314/2013-TCU-Plenário. Brasília: TCU, 28/08/2015.

TEIXEIRA, Ana C; SOUZA, Clóvis H. L.; LIMA, Paula P. F. Arquitetura da Participação no Brasil: Uma Leitura Das Representações Políticas em Espaços Participativos Nacionais. In: Texto para discussão n. 1735, Ipea, Rio de Janeiro, 2012.

TERSO, Tamara. Entrevista concedida a Henrique Carlos Parra Parra Filho. Meio digital, 15 de agosto de 2017.

UNESCO (United Nations Educational, Scientific and Cultural Organization). Defining Egovernance. 27/07/2004. Disponível em: < $\underline{\text { http://www.unesco.org/webworld/e-governance }>\text {. }}$ Acesso em: 14/02/18.

VAZ, José Carlos. Administração Pública e Governança Eletrônica: Possibilidades e Desafios para a Tecnologia da Informação. In: Governo Eletrônico - Os Desafios da Participação Cidadã. Fortaleza: Fundação Konrad Adenauer, Série Debates n. 24, dezembro/2003, p. 1316. Disponível em: $<$ http:/gestaocompartilhada.pbh.gov.br/sites/gestaocompartilhada.pbh.gov.br/files/biblioteca/ arquivos/governo-eletronico-participacao-cidada.pdf $>$ Acesso em: 17/09/2013.

Governança Eletrônica: para onde é possível caminhar? In: Instituto Pólis, 2005. Disponível em: $<$ http://www.polis.org.br/uploads/745/745.pdf $>$. Acesso em: 17/09/2016.

Transformações tecnológicas e perspectivas para a gestão democrática das políticas culturais. In: Cadernos Gestão Pública e Cidadania, v. 22, n. 71, 2017. 
Tecnologia da Informação como Instrumento para a Democratização da Gestão de Políticas Culturais. In: Dossiê Práticas e Políticas Culturais: Paradoxos e diálogos com a tecnologia Arquivos do CMD, Volume 5, N.1. Jan/Jul 2017.

VOORBERG, W.; BEKKERS, V.; TUMMERS, L. Co-creation and Coproduction in Social Innovation: A Systematic Review and Future Research Agenda. In: EGPA Conference, Edimburgo, 11-13 de setembro de 2013.

WHITAKER, Gordon P. Coproduction: Citizen participation in service delivery. In: Public administration review, p. 240-246, 1980.

YOUNG, I. M. Representação política, identidade e minoria. In: Lua Nova, São Paulo, n. 67, 2006, p. 139-190.

ZISSIS, Dimitrios; LEKKAS, Dimitrios; PAPADOPOULOU, Anastasia-Evangelia. Competent Electronic Participation Channels in Electronic Democracy. In: Electronic Journal of e-Government, 2009. 


\section{APÊNDICE A - ROTEIRO GERAL DAS ENTREVISTAS}

1) Conte um pouco de sua trajetória em projetos que envolvam o uso de tecnologias para participação social ou ação política.

2) Conte em suas palavras, o que foi a construção do aplicativo da 3a. Conferência Nacional de Juventude? Quais foram os objetivos dela?

3) Qual foi seu papel/ cargo durante o processo de construção do aplicativo da 3a.

Conferência Nacional de Juventude utilizando a plataforma do Participa.BR? Conte detalhes sobre seu papel neste processo.

4) É de seu conhecimento com qual estrutura (pessoas, equipamentos, orçamento, espaço, etc) a gestão do processo contava?

5) Em sua opinião, quais as principais dificuldades experimentadas durante o processo? E quais foram as soluções encontradas para essas dificuldades?

6) Quais foram as lições aprendidas nesse processo?

7) Você acredita que o governo federal brasileiro esteja preparado para incorporar tecnologias digitais em processos de participação social?

8) Você acredita que iniciativas como essa sejam moda/modismo/pontuais ou têm potencial de serem estruturais/permanentes?

9) Por fim, em sua opinião, quais outros atores foram importantes para esse processo (em especial por parte do governo) que poderiam contribuir para a minha pesquisa?

10) Você teria algo mais a acrescentar?

Referência de questões para aprofundamento destinadas aos entrevistados que se envolveram mais diretamente no desenvolvimento tecnológico (opcionais para serem utilizadas de acordo com as respostas e a dinâmica de cada entrevista):

Que órgão ficou responsável pela contratação (jurídica e financeira) dos serviços de produção das TICs?

A produção das TICs utilizadas na 3a. Conferência Nacional de Juventude utilizou quais softwares e códigos?

Que órgão decidiu a escolha do(s) softwares a serem utilizados?

Como foi a escolha do uso deste software?

Quais as razões para tal escolha e quem foi determinante para tal? 
Qual(is) órgão(s) ficou(eram) responsáveis pela produção das TICs utilizadas pela 3a.

Conferência Nacional de Juventude? Quais ações e atribuições foram desempenhadas (por cada órgão)?

O SERPRO ou algum servidor público participou do desenvolvimento?

Quais seu papel na governança do software?

Como este envolvimento foi formalizado? (do ponto de vista jurídico e econômico)

Algum cidadão (sem vínculo com o serviço público ou com alguma empresa contratada pelo Estado) atuou no desenvolvimento? 